Contract No. and Disclaimer:

This manuscript has been authored by Savannah River Nuclear Solutions, LLC under Contract No. DE-AC09-08SR22470 with the U.S. Department of Energy. The United States Government retains and the publisher, by accepting this article for publication, acknowledges that the United States Government retains a non-exclusive, paid-up, irrevocable, worldwide license to publish or reproduce the published form of this work, or allow others to do so, for United States Government purposes. 


\title{
ENVIRONMENTAL RADIATION MONITORING IN THE CHERNOBYL EXCLUSION ZONE - HISTORY AND RESULTS 25 YEARS AFTER
}

\author{
Mikhail D. Bondarkov, ${ }^{*}$ Boris Ya. Oskolkov, ${ }^{*}$ Sergey P. Gaschak, ${ }^{*}$ \\ Sergey I. Kireev ${ }^{\dagger}$, Andrey M. Maksimenko, ${ }^{*}$ Nikolai I. Proskura ${ }^{\ddagger}$, \\ G. Timothy Jannik, ${ }^{\S}$ and Eduardo B. Farfán ${ }^{\S}$
${ }^{*}$ Chernobyl Center for Nuclear Safety, Radioactive Waste and Radioecology, International Radioecology Laboratory, 07100, Slavutich, Ukraine.
†State Specialized Scientific and Industrial Enterprise Chernobyl Radioecological Center (GSNPP ECOCENTER), Chernobyl, Ukraine
${ }^{\sharp}$ Ministry of Emergencies of Ukraine. State Department - Exclusion Zone Administration, Chernobyl, Ukraine
${ }^{\S}$ Savannah River National Laboratory, Aiken, SC 29808, USA

\section{For reprints and correspondence contact:}

Eduardo B. Farfán, Ph.D.

Environmental Science and Biotechnology

Environmental Analysis Section

Savannah River National Laboratory

Savannah River Nuclear Solutions, LLC

773-42A, Room 236

Aiken, SC 29808

E-mail: Eduardo.Farfan@srnl.doe.gov

Phone: (803) 725-2257, Fax: (803) 725-7673

\section{Part of the Savannah River National Laboratory HPJ Special Issue}

October 2011 


\begin{abstract}
This article describes results of the radiation environmental monitoring performed in the Chernobyl Exclusion Zone (ChEZ) during the period following the 1986 Chernobyl Nuclear Power Plant accident. This article presents a brief overview of five comprehensive reports generated under Contract No. DE-AC09-96SR18500 (Washington Savannah River Company LLC, Subcontract No. AC55559N, SOW No. ON8778) and summarizes characteristics of the ChEZ and its post-accident status and the history of development of the radiation monitoring research in the ChEZ is described. This article addresses characteristics of the radiation monitoring in the ChEZ, its major goals and objectives, and changes of these goals and objectives in the course of time, depending on the tasks associated with the phase of mitigation of the ChNPP accident consequences. The results of the radiation monitoring in the ChEZ during the last 25 years are also provided.
\end{abstract}

Key words: Chernobyl, environmental radioactivity, environmental assessment, environmental monitoring. 


\section{INTRODUCTION}

The management of any contaminated area is based on the monitoring of the environmental status of this area by implementing the following three major functions: observation, assessment, and prediction. In most cases, environmental monitoring includes several areas, such as monitoring of contamination sources (emissions and discharge from industrial and agricultural facilities, vehicles' exhaust, etc.), climatic monitoring (meteorological characteristics, observations over the terrains, hydrology and hydrogeology), and biological monitoring, which identifies the status of the biota and its response and reaction to anthropogenic impacts.

For radiologically contaminated areas, radiation monitoring is an important management tool and it includes (1) monitoring of the sources of contamination impacting the area to assess the human exposure and contribution of each contamination source to the total exposure and (2) monitoring of the distribution of radionuclides in the biosphere components and migration capabilities of the radionuclides in specific environmental chains and their capability to concentrate in individual links of the food chains (i.e., contamination of farmlands, soils, bodies of water, fodder and forage, agricultural plants, and livestock products). Contamination of agricultural plants and livestock products is important because human consumption of agricultural products containing radionuclides is frequently considered the key factor for generating the exposure dose and, in addition, this path of the radiation impact appears to be the most controllable and adjustable. The knowledge of the radioecological characteristics of the ecosystem of the contaminated area is also important for evaluation of the biota exposure, which has recently become an item of growing attention. 
The requirements for organization of programs for conducting radiation monitoring are described in Recommendations of the International Commission on Radiological Protection (ICRP) and International Atomic Energy Agency (IAEA) (ICRP 1985; IAEA 2005, 2010). In the former Soviet Union, the requirements for organization and scope of the environmental radiation monitoring were described in a special guideline (Marey and Zykova 1980) and in sanitation regulations and standards of the atomic energy industry (SP AES-79 1979). This article addresses the organization and conduct of the radiation monitoring performed in one of the most well-known contaminated areas in the world, the Chernobyl Exclusion Zone (ChEZ).

\section{METHODS AND MATERIALS}

\section{Characteristics of the ChEZ}

The accident in the Chernobyl Nuclear Power Plant (ChNPP) Reactor Unit Four that occurred in the early morning of 26 April 1986 is known to have released an enormous quantity of radionuclides from the destroyed reactor. At the time of the accident, Reactor Unit Four had been in operation for 2.4 years (since December 1983). Including gaseous and short-lived radionuclides, the total activity in Reactor Unit Four by the time of the accident was estimated to be 300,107 PBq (8,111 MCi) (Pazukhin 1999) The estimated inventory of the major, long-lived radionuclides in the core is shown in Table 1 . About $3.5 \%$ of this activity was released into the atmosphere to generate the fallout that precipitated onto the adjacent territories. According to different estimates, the total radioactive release (not including noble gases) was approximately 3,330 PBq (90 MCi) (Borovoy and Gagarinsky 2001). The release of the radionuclides from the 
destroyed reactor unit continued from 26 April 1986 to 6 May 1986. The relative (percent of total) daily release of radionuclides into the atmosphere is shown in Fig. 1.

The beginning of the existence of the ChEZ should be considered 2 May 1986. As known, on 27 April 1986, the second day after the accident, due to a severe deterioration of the radiation situation, a decision was made to evacuate the population from the city of Pripyat. However, the continuing release of radionuclides from the destroyed reactor required evacuation of the population from a larger area and, on 2 May 1986, the Government Commission headed by N.I. Ryzhkov (then Chairman of the USSR Council of Ministers) made a decision to evacuate the population from the area within a $30 \mathrm{~km}$ radius. Soon afterwards, by 10 May 1986, the USSR State Committee on Hydrometeorology (Goskomgidromet) released an updated map of the contaminated areas shown in Fig. 2 (Izrael et al. 1990). Taking into account the provisional annual maximum allowable dose limitation of $100 \mathrm{mSv}$ recommended by the USSR Ministry of Health (Minzdrav) for the population during the first year after the ChNPP accident, the Government Commission established the following three zones:

1) the exclusion zone, from which the population is to be evacuated and never to return: located inside the dose rate line of $0.2 \mathrm{mSv} \mathrm{hr}^{-1}\left(20 \mathrm{mrem} \mathrm{hr}^{-1}\right)$ ("black zone");

2) the zone of temporary evacuation, where the public may be allowed to return when the radiation situation normalizes: located between the dose rate lines of $0.05-0.2 \mathrm{mSv} \mathrm{hr}^{-1}$ (5-20 mrem hr $\left.{ }^{-1}\right)$ (“red zone"); and

3) the zone of rigorous monitoring, from which children and pregnant women were evacuated into "clean" areas for the summer of 1986: located between the dose rate lines of $0.03-0.05 \mathrm{mSv} \mathrm{hr}^{-1}$ (3-5 $\left.\mathrm{mrem} \mathrm{hr}^{-1}\right)$ ("blue zone”). 
Based on the assessments of the dose exposures associated with all factors of the radiation impact, the population was evacuated from areas with a potential to exceed the maximum allowable dose of $100 \mathrm{mSv}$. The summarized data on the population evacuation from the $30 \mathrm{~km}$ area and adjacent territories in 1986 are provided in Table 2 (Alexsakhin et al. 2001). Therefore, the final demarcation of the area that subsequently received an unofficial name of the "Chernobyl Exclusion Zone" (ChEZ) resulted from adding the "dose rate" zones (dose criterion) to the "geometric" zones ( $30 \mathrm{~km}$ radius) of the evacuation.

In 1992-1993, as a result of in-depth studies and after Ukraine passed the law: On Legal Status of the Territory Exposed to the Radioactive Contamination resulting from the ChNPP Accident, some additional evacuations from several areas of the Polesye Region were performed. In 1997, the evacuated areas of the Polesye and Narodichsky Regions joined the ChEZ and the entire extended area received the name of Exclusion Zone and Zone of Involuntary (Mandatory) Resettlement (Fig. 3). Currently, this total area comprises about $2,600 \mathrm{~km}^{2}$.

Geographically, the ChEZ is located in the southwestern part of the East European Plain in the area of the Kiev Polesye Region that is part of the Polesye Lowlands. Prior to the accident, the Chernobyl District included 64 cities and towns under the jurisdiction of city Soviets and 20 villages under the jurisdiction of rural Soviets. The cities of Pripyat (60,000 people) and the city of Chernobyl (12,000 people) became part of the ChEZ. Woods and forests occupy about $45 \%$ of the exclusion zone, fields occupy $30 \%$, and grassland and meadows occupy $10 \%$.

The ChEZ is located in a predominately mixed forest area, which includes about 20 different types of landscapes. Geomorphologically, this area is part of the RozvazhevskyChernobyl morainic-outwash plain having a glacial origin, with areas of outwash and loessial 
plains. The elevation of the area is relatively even with higher elevations (115-140 m) on the right bank of the Pripyat River. The elevation of the Pripyat River left bank mostly ranges from 105 to $120 \mathrm{~m}$ (hereinafter the elevations are given in the Baltic System of Elevations). The average elevation of the Pripyat River is about $104 \mathrm{~m}$ and the elevation of the ChNPP Site is 114 $\mathrm{m}$. The morainic plain presented by rock outcrops was preserved in the area of the city of Chernobyl. The second and first terraces above the floodplain and the floodplain itself represent terrains of alluvial origin on the right bank of the Pripyat River.

The soils in the ChEZ are varied, with sod podzol sand and silt sandy soils prevailing. Gleic soils that are characteristic of morainic-glacial plains and above the floodplain terraces are less common. At lower elevations, peat bog soils and organogenic soils are common. Grassland soils with a thin fertile layer prevail in the floodplain. Regarding their mechanical composition, the soils are primarily sandy loam. Calcium prevails as an exchange cation, but its content is not high (about $5 \mathrm{mg}$ per $100 \mathrm{~g}$ of soil in the humus layer). The exchange calcium is an important indicator of ${ }^{90} \mathrm{Sr}$ migration capability in soils. Most of the area around the ChNPP is covered with podzol and gleic-sandy soils with fairly low sorption characteristics and low calcium content. The humus content ranges from 0.70 to $1.68 \%$.

There are several bodies of water in the ChEZ, and water covers over $10 \%$ of the entire area. The major rivers in the ChEZ are the Pripyat, Uzh, Sakhan, Ilya, and Braginka. The major confined water reservoirs are the ChNPP Cooling Pond, Pripyatsky and Semikhodovsky (Yanovsky) backwater ponds separated by the levees in 1987, Azbuchin Lake, and a network of polder water reservoirs on the left bank of the Pripyat River. All major permanent and temporary waterways belong to the Pripyat River Basin with the exception of the Braginka River that flows independently into the Kiev Water Reservoir. The density of the hydrographic network ranges 
from 0.32 to $0.39 \mathrm{~km} \mathrm{~km}^{-2}$. To stabilize the Pripyat riverbed, levees were built along both banks to prevent flooding. The Pripyat River floodplain is delineated by the first above the floodplain terrace in the north-western and south-western sections of the area. The first above the floodplain terrace is 4 to $9 \mathrm{~m}$ high (the absolute elevation of the area ranges from 110 to $116 \mathrm{~m}$ ). Its terrain is represented by a complex structure of swampy grassland and saucer-shaped cavities separated with extended hills and water divisions. The ChNPP site is located in the upper terrace. The absolute elevations of the natural terrain range from 113 to $116 \mathrm{~m}$.

The Pripyat River is the major waterway that crosses the ChEZ from northwest to the southeast flowing into the Kiev Water Reservoir. The river is $780 \mathrm{~km}$ long, with over $50 \mathrm{~km}$ from the village of Dovlyady to the mouth of the river flowing within the ChEZ. The watershed area within the ChEZ is about 2,000 $\mathrm{km}^{2}$ (the ChNPP Cooling Pond comprises slightly over $1.1 \%$ of this area). In the $13 \mathrm{~km}$ long area, the Pripyat River flows in a partially man-made canal along the ChNPP Cooling Pond. The width of this canal ranges from 120 to $180 \mathrm{~m}$ and the average depths range from 2.5 to $4 \mathrm{~m}$, with the maximum depths reaching from $6 \mathrm{~m}$ to $8 \mathrm{~m}$. The average annual water flow rate of the Pripyat River at the ChNPP Site intake is $420 \mathrm{~m}^{3} \mathrm{~s}^{-1}$. The estimated maximum flow rate with the exceedance probability of $0.01 \%$ is $13,000 \mathrm{~m}^{3} \mathrm{~s}^{-1} ; 1 \%$ of the exceedance probability is $6,000 \mathrm{~m}^{3} \mathrm{~s}^{-1}$. The average minimum monthly flow rate at the $97 \%$ exceedance probability is $61 \mathrm{~m}^{3} \mathrm{~s}^{-1}$ under ice free conditions and about $56 \mathrm{~m}^{3} \mathrm{~s}^{-1}$ with ice drifts. The maximum Pripyat River water level at the ChNPP pump station water intake $(0.01 \%$ exceedance probability) is $111.3 \mathrm{~m}$ (the Baltic Elevation System) (Shestopalov et al. 2001).

The flora in the Kiev Polesye is diverse and contains over 1,300 plant species (over 1,500 were reported in some publications), with over 400 species introduced by humans. Currently 49 plant species within the ChEZ are declared endangered and they were either listed in the Red 
Book of Ukraine or subject to protection according to the International Conventions ratified by Ukraine (Petrov 2006). Prior to the ChNPP accident, the flora in the ChNPP area was represented by a mosaic combination of grassland and farmlands, as well as deciduous and coniferous (pinewood) forests. Currently, areas covered with forests continuously expand with abandoned farmlands and meadows gradually transforming to wooded areas. The major forest species in the ChEZ have always been and remain pine, birch, alder, oak, and aspen. Coniferous forests cover about $38 \%$ and deciduous forests (birch, alder, oak, and aspen) cover up to $10 \%$ of all the wooded areas. Foreign species for the ChEZ are Banx Pine and White Acacia. Herbaceous vegetation is hardly present in the coniferous forests where $60-80 \%$ of the area is covered with moss. Areas with a significant herbaceous cenosis are not large (less than $1 \%$ of the ChEZ) and they are mostly associated with quazi-natural pine and oak woods with cobnut and buckthorn shrubs and other well-developed shrub vegetation, including elements of pine and oak woods. Aquatic swamp biocenoses cover a significant part of the ChEZ, with swamps covering approximately $2.6 \%$ of the entire area.

According to the available biological data, up to 409 vertebrate species are likely to inhabit the current ChEZ where scientists have identified up to 20 terrestrial and aqueous fauna complexes. Seventeen endangered species (listed in the Red Book) have been positively identified in the ChEZ, with as many as 54 endangered species likely to be present (Gashchak et al. 2006a).

Birds prevail among vertebrate species and about 245 bird species are likely to be present in the ChEZ, including 161 species with confirmed nesting in the area. Forty-eight species of birds have been confirmed to stay in the ChEZ for winter; however, 64 species are likely to stay. The remaining species are migratory. Overall, the avian fauna is represented by 52 families, 
including passerines (94 species), plovers (42 species), and ancerines (23 species). Regarding semi-aquatic birds, mallards, garganey teals, sandpipers, and seagulls are the most common. Geese, whooping swans, herons (gray, large, small, white, and purple), and bitterns can also be observed. Black cocks and grouses are the most common species in woods, while bustards' nests can occasionally be seen in the grassland. Pigeons are also common ( 5 species). Regarding birds of prey, the most common species are small falcons (red-footed falcons, hobby falcons, and kestrels), hawks, and owls while ospreys, white-tailed eagles, and golden eagles are rare (Gashchak et al. 2006a). It should be noted that the speciation and quantities of the population of birds in the ChEZ are constantly changing due to active ecological succession processes.

Fewer mammals inhabit the Polesye Region, which is host to a total of about 70 species. Currently, the habitation of 47 mammal species, including three endangered species, has been confirmed and approximately 16 or 17 chiropterans inhabit the ChEZ. Regarding predators, wolves, foxes, raccoon dogs (acclimated in 1936), and European lynx can be observed in remote wooded areas. The Mustelide family is presented by 9 species, including martens, black ferrets, badgers, weasels, ermines, and American minks. The population of cloven-hoofed animals grows, with wild boars, roe deer, moose, and elk being ubiquitous.

European hares inhabit edges of the forests and ravines. There are grounds to believe that the ChEZ will become a place of resurgence of a blue hare that was practically eliminated in these regions of Europe. Rodents, such as field mice, several types of voles, house mice, etc. are very common and a total of 18 species of rodents have been reported. In $1944-1946$, muskrats were brought into Polesye and they acclimated well. During the post-Chernobyl period, the population of beavers also grew significantly. 
It is estimated that 65 fish species, including Cyprinidae, Percidae, Siluridae, etc., reportedly inhabit the water reservoirs of the ChEZ, however, habitation of 48 fish species have been confirmed to date. The most common species are bream, silver bream, crucian carp, roach, perch, pike, pike perch, carp, catfish, and ruff. Eleven amphibian species inhabit the ChEZ, including four species of toads, frogs, newts, and seven reptile species.

About 207 species of the local fauna are protected by the International Convention on Protection of the Wild Flora and Fauna and Natural Habitats in Europe (Bern Convention). In addition, the ChEZ, as the intersection of major migratory routes of the avian fauna (Pripyatsky and Dneprovsky migratory routes), is subject to protection according to the Bonn Convention on Preservation of Migratory Species of Wild Animals, 1979 (Gaschak et al. 2006b).

The ChEZ contains 11 sites of the Ukrainian Natural Preservation Fund that had existed prior to the ChNPP accident. In 2007, the Chernobyl Regional Special Zoological Preserve was founded in the ChEZ. According to the Ukrainian Law entitled: On Legal Status of the Territory Exposed to the Radioactive Contamination Resulting from the ChNPP Accident, the Chernobyl Exclusion Zone and the Zone of the Involuntary (Mandatory) Resettlement have a special form of administrative management called the Exclusion Zone Administration. No economic activities are authorized in the ChEZ, which is classified as a contaminated area and separated from adjacent territories. Inhabiting the ChEZ or performing any economic activity that is not related to mitigation of the ChNPP accident consequences are prohibited. 


\section{Radiation monitoring programs in the ChEZ}

Prior to the 1986 accident, environmental monitoring at the ChNPP site (atmosphere, hydrosphere, and lithosphere monitoring) was performed by the ChNPP Office of Labor and Occupational Safety. Regarding the radiation safety, this Office had the following functions:

- Monitor the radiation situation using standard stationary systems and portable dosimeters at the ChNPP's indoor facilities and throughout the ChNPP site (operational personnel);

- Monitor the source: sampling and analysis of gaseous and aqueous discharge (reactor cooling water, liquid radioactive waste, floor drainage and wastewater) - Radiometric Laboratory;

- Monitor the radiation situation within the protected area $(3 \mathrm{~km}$ radius around the ChNPP site) and within the supervised area (aproximately $10 \mathrm{~km}$ radius around the ChNPP site) - External Health Physics Laboratory;

- Provide for individual radiological control for the operational personnel - Health Physics Laboratory and Radiometric Laboratory; and

- Provide for calibration, maintenance, and repairs of the measurements instrumentation of the automated radiation monitoring system - Radiotechnical Laboratory.

Standard stationary automated monitoring systems included the Sistema 8004-01 measurement instrumentation system at the ChNPP Phase I and Gorbach-AKRB-06 at the ChNPP Phase II. The sensors of these systems, with the maximum measurable gamma exposure dose rate of $999 \mathrm{mR} \mathrm{hr}^{-1}$ (up to $1,000 \mathrm{R} \mathrm{hr}^{-1}$ in the reactor room), were only installed inside the ChNPP facilities. No automatic gamma dose rate monitoring was provided outside the ChNPP 
buildings. The External Health Physics Laboratory was located in a stand alone building in the outskirts of the city of Pripyat. The Laboratory routinely conducted required measurements within the protected area ( $3 \mathrm{~km}$ radius around the ChNPP site) and the supervised area (10 km radius around the ChNPP site).

According to the applicable recommendations (Marey and Zykova 1980), the ChNPP protected and supervised areas contained 38 radiation monitoring stations for monitoring airborne contamination, precipitation, gamma exposure dose rate, soils, and vegetation. Eleven out of these 36 stations were equipped with air samplers installed for monitoring radioactive aerosol content in the air, 34 stations had vials to sample the precipitation, and 13 stations installed in the major water reservoirs affected by the ChNPP site operations had water samplers to monitor the radionuclide concentrations in the water, bottom deposits, and hydrobionts. Local farm products were monitored in nine villages located within the $10 \mathrm{~km}$ radius around the ChNPP site. All the measurement systems utilized for the monitoring needs prior to the ChNPP accident were operational, certified, and properly calibrated. They had national calibration certificates issued by the Belotserkovsky Center of Standardization. The radiation monitoring fully complied with the applicable regulatory documents.

The accident at the ChNPP Reactor Unit Four created an extremely challenging radiation situation at the ChNPP site requiring urgent and large-scale activities for the radiation monitoring. The Union of Soviet Socialist Republics (USSR) Ministry of Defense, the Civil Defense, and the USSR Goskomgidromet organizations, as well as other agencies, were involved in providing the radiation monitoring. According to the decision made by the Governmental Commission on 6 May 1986, an Interdepartmental Radiation Monitoring Group was formed to 
coordinate the activities of those agencies and organizations that were involved in the radiation monitoring efforts.

During the first days following the accident, the USSR Ministry of Defense performed radiation monitoring in 183 locations within the $30 \mathrm{~km}$ radius around the ChNPP site and in 53 locations in the adjacent territory. The efforts of the ChNPP External Health Physics Laboratory were extremely limited and practically no routine radiation monitoring was conducted at that time. At the end of May 1986, the Governmental Commission made a decision to employ up to 450 people at the newly formed ChNPP Radiation Safety Division and provide for its adequate equipment and instrumentation borrowing the capabilities from similar organizations at other nuclear power plants in the country. The new structure of the Radiation Safety Division for the ChNPP site and the $30 \mathrm{~km}$ zone was developed and approved in August 1986 to include the following organizations: Office of External Health Physics, Individual Radiation Control Shop, Health Physics and Electronic Equipment Repairs Shop. However, the progress in staffing and providing all necessary equipment and tools for the new organization was extremely slow (Samoylenko et al. 1989).

Upon completion of construction of the Shelter Facility (the Sarcophagus) and recommissioning of Reactor Units One and Two in November 1986, it became clear that it would not be possible to consider the ChNPP accident mitigation work finished at that time. A decision was made to conduct decontamination and recommissioning of Reactor Unit Three, as well as continue large-scale activities on decontamination, collection, and the disposal of the newly generated radioactive waste. To perform these activities, a special organization called Kombinat Industrial Association was formed in November 1986. The Kombinat Industrial 
Association included a Health Physics Division that was tasked with preparations and conduct of the radiation monitoring activities inside the ChEZ.

During 1987-1988, large-scale comprehensive radiation monitoring efforts were developed. At that time, a large number of radiation monitoring stations were deployed and the measurements labs were equipped with the required radiometric instrumentation, such as semiconductor $\gamma$-spectrometers with DGDK detectors, multi-channel amplitude analyzers LP4840 , and with the radiochemical equipment.

By 1989, the monitoring network of the Kombinat Health Physics Division included 78 stations for air monitoring, 42 stations for the fallout monitoring, 20 hydrological surface water monitoring stations, and 60 underground water monitoring stations for the most contaminated areas, as well as for the locations of the interim radioactive waste disposals and immobilization. Apart from the stationary health physics stations, single-time or seasonal environmental samples were also obtained on a regular basis. Single-time and seasonal sampling was applied; specifically, for sampling the groundwater during the spring and fall flooding seasons, snow sampling during the snow melting season, and air sampling in the locations of the exposed contaminated soils in spring and summer. A large number of the single-time sampling locations (over 30,000 within the $60 \mathrm{~km}$ Zone) were used for developing detailed soil contamination maps of the ChEZ (Gavrikov et al. 1989).

In 1986, the domestic automated radiation monitoring system (the ASKRO System) was designed, manufactured, and commissioned. In 1987, an automatic meteorological station was installed and a radiation monitoring station was commissioned. In addition, radiological monitoring of the water in the ChNPP feed and discharge canals was established. In 1988, an 
automated off-gas monitoring system was installed at the ChNPP ventilation stacks with the ability to collect and submit the air monitoring data to external users.

By 1989, the ChEZ radiation monitoring system included an extensive number of monitoring stations, approved measurements procedures, certified sampling and measurements methodologies, and calibrated equipment. The monitoring capabilities at that time made it possible to assess the radiation status of the major natural and technogenic components in the ChEZ, with the following parameters being monitored:

- Exposure dose rate: 36 monitoring points/stations;

- Contamination density: 150 stations;

- Airborne radionuclide concentration: 23 stations;

- Precipitation: 31 stations;

- Radionuclide concentration in the surface and underground water (107 wells), drinking water (3 wells), and wastewater (6 stations);

- Radionuclide content in bottom deposit samples in the ChEZ major bodies of water;

- Radionuclide content in biota samples (vegetation, mushrooms, fish, etc.); and

- Various hydro-meteorological parameters.

After the Verkhovna Rada of Ukraine approved the Concept of the Chernobyl Exclusion Zone in the territory of Ukraine in 1992, the Administration of the ChEZ and the Zone of Involuntary (Mandatory) Resettlement performed a number of administrative activities to upgrade the radiation monitoring system in the ChEZ. The observation network was upgraded and expanded. The regulatory framework was improved to include the methodological principles for operation of the radioecological monitoring system: studied objects and their locations, composition and scope of observations, frequencies, and types and quantities of the mandatory 
measurements. In 1993, Ukraine began development of the national environmental monitoring system and the radiation environmental monitoring of the ChEZ became one of the key elements of this system.

Since the creation of the ChEZ, its radiation monitoring system and radiation monitoring objectives significantly differed from the routine radiation monitoring systems that existed prior to the accident. Primarily, these differences are related to the (1) unprecedented contamination levels, (2) variety of physical and chemical forms, (3) extreme spatial heterogeneity of contamination, and (4) geographical scale of contamination. The ChEZ monitoring goals and objectives also had to consider (1) the prevention of excessive radiation exposure of the population and personnel, (2) making provisions for post-ChNPP accident long-term activities, and (3) gaining insight into the processes of radionuclide contamination fate and transport and its subsequent impact on the environment.

The radiation monitoring system described above was established to solve these goals and objectives. The radiation monitoring activities were performed by the Health Physics Division (by the Kombinat Production Association followed by the Pripyat Scientific and Production Association), then by the State Scientific Industrial Enterprise for the Regional Environmental Monitoring Radek (DSNVP Radek) and since April 2000, by the State Specialized Scientific and Production Center EcoCenter (DSNVP EcoCenter 1995-2010).

During the last 25 years, the monitoring activities and the associated monitoring stations underwent continuous improvements. The current monitoring system is comprised of 146 various monitoring locations, such as operational facilities, field sites, hydrologic sections, air sampling and fallout locations, 138 observation bore wells, and 11 residential communities. In 2000, the measurements laboratory was relocated from the city of Pripyat, where it had been 
originally installed in the ChNPP External Health Physics Laboratory to a newly refurbished facility in the city of Chernobyl with better measurements conditions. This new Laboratory of Instrumental Methods of Studies (LIMD) has modern equipment and instrumentation, such as the gamma spectrometric system including multi-channel analyzer ORTEC 919, USA, gamma detectors Canberra GC-2518, Canberra 7229, Ortec GEM-25180-P-S, and PGT IGC -24; singlechannel analyzer Ortec-926; multi-channel analyzer Nokia-4900B with X-ray detectors Canberra GL-2020R, Ortec LOAX 51370/20; Canberra alpha-spectrometry system Alpha Analyst, and other related equipment. All the equipment and instrumentation are calibrated and certified in compliance with applicable Ukrainian regulations. The LIMD was accredited by the National Meteorological Oversight of Ukraine and authorized to conduct public health and environmental safety measurements (Certificate of Accreditation Number 70A-34-07 of 27 July 2007). From March to April of 2009, the LIMD participated in the IAEA inter-calibration tests under a project titled "IAEA-2003-03 Proficiency Test on Determination of Natural Radionuclides in Phosphogypsum and Spiked Water." The measurements results received by the LIMD in June 2009 proved to be within the limit of error of the IAEA measurements.

Due to the aging of the ASKRO system equipment (Tunets), an upgraded monitoring system, called Automated Monitoring ASKRS SkyLink System, was commissioned in 2007 under the TACIS U4.01/03S Project with support from the European Union. The ASKRS SkyLink System included 39 stations for measuring equivalent dose rates using GammaTracer instruments, an automatic meteorological station, and 18 air sampling stations for measuring airborne contamination (Fig. 3). All of the exposure dose rate data are transmitted to the Operations Dispatch Center in the city of Chernobyl using radio communication equipment. 
The environmental radiation monitoring currently performed in the ChEZ is conducted in compliance with the DSNVP EcoCenter Regulation (hereinafter referred to as the Regulation) on Radiation Environmental Monitoring and Health Physics Measurements in the Exclusion Zone and Zone of Involuntary (Mandatory) Resettlement that has to be reviewed by such regulatory agencies as the Ukrainian National Nuclear Regulatory Inspectorate (DKYaRU), the Ministry of Nature, and the Ministry of Health. Then it has to be approved by the Head of the State Department of the Administration of the Exclusion Zone (DSNVP EcoCenter 2009).

In accordance with the Regulation, in 2009, over 880 soil samples, approximately 1,400 air and precipitation samples, over 1,300 surface and groundwater samples, and 700 biological samples (totaling over 4,490 samples) were taken and analyzed. In addition, there were about 1,250 field hydro-geological and hydrometric measurements performed. In total, over 9,950 laboratory radiochemical and spectrometric analytical measurements were made in 2009, mainly to assess the concentrations levels of ${ }^{137} \mathrm{Cs}$ and ${ }^{90} \mathrm{Sr}$ in the various media.

As mentioned, one of the major radiation monitoring tasks in the ChEZ is associated with assessment and prediction of potential ChNPP accident related exposure doses for the public and operational personnel, and potential radiation damage to individual biota and the overall ecosystem. To gain a better understanding of the radionuclide transport processes and radionuclide accumulation in the biogeocenosis elements, a specialized monitoring of individual elements of the regional ecosystem has to be conducted. For this purpose, scientific organizations from the former Soviet Union (Goskomgidromet, the USSR Academy of Science) and Ukrainian organizations (Ukrainian Research Hydro-meteorological Institute and the following organizations within the National Academy of Sciences of Ukraine: Institute of Geological Sciences, the Research Institute of Radioecological Field Studies, Institute of the 
Environmental Geochemistry, Institute of Hydrobiology, Institute of Botany, Institute of Geography, the Institute of Radioecology of the Ukrainian Academy of Agricultural Sciences, and the Scientific Center of Radiation Medicine of the Ukrainian Ministry of Health) were heavily involved. Specifically, in the period between 1989 and 1991, more than 120 scientific organizations of Ukraine, Russia, and Belarus participated in the activities conducted in the ChEZ (Senin 1992).

Other organizations that are based within the ChEZ also perform monitoring activities there. Such organizations include: the State Enterprise ChAES (monitoring radioactive releases and discharges from the ChNPP reactor units), International Scientific and Technical Center Ukrytie (monitoring the environmental impact of the ChNPP Shelter Facility), State Specialized Enterprise ChernobylLes (currently called Chernobylputscha), State Enterprise Chernobylvodexpluatatsiya, State Specialized Enterprise Tekhnocentr, and the International Radioecology Laboratory (IRL) in the city of Slavutich. Scientific organizations from France, Japan, USA, United Kingdom, Germany, and Canada also participate in some aspects of the monitoring studies in the ChEZ.

\section{RESULTS AND DISCUSSION}

\section{5-y History of radiological monitoring results in the ChEZ}


The major source of the radiation impact in the ChEZ is associated with the radioactive materials that were released into the environment after the ChNPP accident in 1986. The current estimated ChNPP related radionuclide inventory within the ChEZ is shown in Table 3.

\section{Gamma dose rate monitoring results (the ASKRO data)}

The field gamma dose rate is one of the most easily monitored parameters and one of the most important elements for assuring radiation safety. Therefore, the gamma dose monitoring was performed since the onset of the ChNPP accident emergency situation by the radiation survey teams of the USSR Ministry of Defense and Goskomgidromet. In addition, more target specific studies were performed by special groups from various organizations. According to the performed measurements, by mid-1987, the isoline with an exposure rate of $2.58 \times 10^{-6}\left(\mathrm{mR} \mathrm{hr}^{-1}\right)$ covered $1 / 6$ of the entire $30 \mathrm{~km}$ area around the ChNPP. The major radionuclides of concern were: cerium isotopes with a contribution of 40 to $45 \%$ and half-life of up to $285 \mathrm{~d}$, cesium isotopes with a contribution of $10 \%$ and half-life of up to $30 \mathrm{y}$, ruthenium isotopes with a contribution of $20 \%$ and half-life of up to $1 \mathrm{y}$, and strontium isotopes with a contribution of $10 \%$ and half-life of up to $29.5 \mathrm{y}$.

The systematic exposure rate monitoring using the ASKRO system started in 1987. The locations of the ASKRO monitoring stations are shown in Fig. 3. Prior to the refurbishment of the ASKRO system, it utilized BDMG-08R detectors with the exposure rate measurement range from $2.58 \times 10^{-9}$ to $2.58 \times 10^{-6} \mathrm{C} \mathrm{kg}^{-1}\left(10 \mu \mathrm{Rhr}^{-1}\right.$ to $\left.10 \mathrm{mR} \mathrm{hr}^{-1}\right)$ with an uncertainty of $\pm 40 \%$ at the 0.95 confidence level. The BDMG-08R detectors were placed $1 \mathrm{~m}$ above the ground surface. The recorded exposure rate value was formed by gamma rays emanating from the ground surface in the circular area with a radius of about $50 \mathrm{~m}$ around the detector. 
Immediately following the ChNPP accident, the gamma doses recorded in the ChEZ mostly resulted from short-lived radionuclides, such as ${ }^{95} \mathrm{Nb},{ }^{95} \mathrm{Zr},{ }^{103} \mathrm{Ru},{ }^{106} \mathrm{Ru},{ }^{13 \mathrm{I}} \mathrm{I},{ }^{134} \mathrm{Cs},{ }^{137} \mathrm{Cs}$, ${ }^{140} \mathrm{La},{ }^{141} \mathrm{Ce}$, and ${ }^{\mathrm{I} 44} \mathrm{Ce}$. In the subsequent years, due to physical decay, the ${ }^{137} \mathrm{Cs}$ isotope remaining in the upper soil layers became the major source of gamma radiation. Table 4 shows the decrease in the external radiation dose rate during the first few years following the ChNPP accident at several monitoring locations.

Since 1993, the decrease in the external radiation dose within the ChEZ changes more gradually and is mostly affected by the following two processes: physical decay and contaminant transport into deeper layers of the soils (Fig. 4). The highest dose rates were recorded within the ChNPP Industrial Site, specifically, in the area of the liquid and solid radioactive waste storage facility, the water intake station, and spent nuclear fuel storage facility. All these facilities are adjacent to the destroyed reactor unit where the accident occurred and despite comprehensive mitigation and remediation activities, they maintain high contamination levels.

In the 10-km supervised area, relatively high dose rates were recorded at the Chistogalovka and Kopachi ASKRO monitoring stations and the lowest levels were recorded at the Staroselye and Benevka ASKRO monitoring stations. Outside the $10 \mathrm{~km}$ supervised area, higher dose rates were recorded at the Usov and Buryakovka ASKRO stations. During the ChNPP accident, the villages of Usov and Buryakovka were located along the northwestern plume fallout plume. The lowest dose rates were recorded at the Stechanka and Dityatki ASKRO stations to the south.

The average monthly equivalent dose rates for 2009 recorded at the new SkyLink ASKRS stations equipped with new Gamma-Tracer sensors are shown in Fig. 5. Comparisons of the data obtained using the old and the new system is difficult because the Gamma-Tracer 
sensors are significantly different from the earlier operated BDMG-08R sensors of the old Tunets ASKRO system both regarding their technical specifications and installation configurations. The old sensors were installed $1 \mathrm{~m}$ above the ground level and the new sensors were installed $4 \mathrm{~m}$ above the ground level, thus increasing the area of measured gamma radiation by a factor of 16 and causing major deviations in the recorded values due to an extremely heterogeneous contamination distribution. The SkyLink/Tunets exposure dose rate ratio ranges from 0.5 to 3 and depends on the distribution of the soil contamination levels in the location of the sensor installation (Godun 2009).

The average monthly gamma dose rate changes relatively little on an annual basis (Fig. 5). However, seasonal changes are observed, specifically influenced by snow coverage (Fig. 6). As shown in Fig. 4, for the past 15 y (1995-2009), the average dose rate in the city of Slavutich (where most workers at the ChNPP Site and the ChEZ live) ranged from 0.2 to $0.25 \mu \mathrm{Sv} \mathrm{h}^{-1}$.

During the first phase of the ChNPP accident mitigation, monitoring external gamma radiation played an important role in assuring the safety of the people within the ChEZ. Currently, the number of the personnel who work at the ChNPP was significantly reduced when Reactor Units One, Two, and Three were shut down and decommissioned. External gamma radiation monitoring is now only important as emergency monitoring associated with inadvertent situations at the Shelter Facility, extreme weather conditions, and natural disasters.

\section{Radioactive contamination of soils in ChEZ}

The major radiological impact in the ChEZ is associated with the radionuclide fallout resulting from the ChNPP accident and this is the main reason why contaminant distribution was 
one of the first and foremost important areas of radiation monitoring immediately following the accident. For this purpose, gamma surveys were performed using special planes provided by Goskomgidromet and the USSR Ministry of Defense and field survey measurements were performed by the chemical defense troops of the USSR Ministry of Defense.

In early May 1986, the first contamination maps were developed (Fig. 2). These maps were continuously improved and updated using ground level measurements (soil sampling and assessment) and aerial gamma surveys (Izrael et al. 1990). From June to December of 1986, the first comprehensive assessments of the ChEZ radiation status were performed by the Radiation Situation Monitoring Special Operations Group of the USSR Ministry of Energy that included specialists from the Dzerzhinsky Research Heat Engineering Institute (VTI) and SoyuzTekhenergo. These studies were conducted in accordance with the programs developed by the USSR Ministry of Energy Headquarters and Radiation Monitoring Operational Group (OMGRO) formed by the Governmental Commission. ChNPP Radiation safety offices also participated in these assessments. In June 1986, the contamination levels in soil samples from the city of Chernobyl were measured (Table 5). The data show that short-lived fission products prevailed in the radionuclide composition, with the major contribution to the gamma dose resulting from ${ }^{95} \mathrm{Zr}$ and its daughter radionuclide ${ }^{95} \mathrm{Nb}$ (about $70 \%$ ). At that time, nearly $100 \%$ of the radioactivity was located in the $1 \mathrm{~cm}$ upper soil layer.

In 1987-1988, the soil contamination studies focused on the spatial distribution followed by mapping of the contaminated areas. Large-scale studies were performed under the Reper Program by the Kombinat Health Physics Division and organizations of the USSR Ministry of Defense and Goskomgidromet (Gavriluk et al. 1990). 
The Reper Program included soil sampling from the $5 \mathrm{~cm}$ deep soil layer within a $60 \mathrm{~km}$ radius around the ChNPP. Soil was sampled every 10 angular degrees (36 samples per ring) at distances of $5,6,7,8,10,12,14.5,17,20,25,30,37.5,45,52.5$, and $60 \mathrm{~km}$ away from the ChNPP resulting in a total of 540 samples. The soil sampling was performed annually in spring or in summer using this "ring" collection method with a $15 \mathrm{~cm}$ diameter sampler. In 1987, five samples were obtained at each sampling location using the "envelope" (5 point) pattern and in 1988 three samples were taken at each sampling location using a triangular pattern. The obtained results were used for developing the more detailed contaminant distribution maps (Figs 8 and 9).

The analysis of the gamma spectrometric measurements of the soil samples taken from 1987 to 1990 made it possible to confirm that the ChNPP accident related radioactive fallout represented an overlapping of the following two components: the "fuel" component (dispersed particles of the nuclear fuel matrix) and the "condensation" component (which included aerosols resulting from condensation of low melting point elements). The primary "condensate" radionuclides were ${ }^{134} \mathrm{Cs},{ }^{137} \mathrm{Cs}$, and ${ }^{144} \mathrm{Ce}$, which were volatilized during the combustion of the reactor graphite.

It was experimentally proven that the radioactive contamination in the ChEZ was extremely variable and large changes in the contamination densities were observed even in locations several meters away from each other. The statistically valid data set showed that, within the $10 \mathrm{~km}$ radius ChNPP area, the fallout composition was similar to the composition of the pre-accident reactor fuel regarding its ${ }^{137} \mathrm{Cs}$ to ${ }^{144} \mathrm{Ce}$ ratio. In addition, the soil contamination was primarily due to the presence of the fuel particles, making it possible to use ${ }^{137} \mathrm{Cs}$ as the baseline isotope for assessing the transuranic radionuclides in this "proximity" zone. In addition, the solubility of the fuel particles was shown to be very low under the natural conditions at that 
phase, preventing the radionuclides in the fuel particles from entering the biological chains. The original ${ }^{90} \mathrm{Sr}$ distribution in the $5 \mathrm{~km}$ area around the ChNNP site was obtained by the Kombinat Health Physics Division in 1989 (Vasilchenko et al. 1990).

By 1994, the short-lived radionuclides such as ${ }^{144} \mathrm{Ce}\left(\mathrm{T}_{1 / 2}=284 \mathrm{~d}\right)$ and ${ }^{106} \mathrm{Ru}\left(\mathrm{T}_{1 / 2}=1 \mathrm{y}\right)$ were practically undetectable by the spectrometric instrumentation and since 1994, the radionuclide composition of the soil contamination was mostly characterized by longer-lived radionuclides, such as ${ }^{137} \mathrm{Cs},{ }^{90} \mathrm{Sr},{ }^{238} \mathrm{Pu},{ }^{239+240} \mathrm{Pu},{ }^{241} \mathrm{Pu}$, and ${ }^{241} \mathrm{Am}$. The radionuclide composition in the upper soil layer identified by direct radiochemical measurements in 1994 is provided in Tables 6 and 7 and the percent contribution of each of the main radionuclides within the proximity zone (5 $\mathrm{km}$ radius) is shown in Table 8 (Ivanov 1994).

The extensive soil monitoring results made it possible to estimate the total radionuclide inventory in the ChEZ soil as shown in Table 9. The monitoring data also were used to update the maps showing the radioactive contamination distribution in the ChEZ at that time. However, subsequent studies demonstrated that those earlier assessments were not fully consistent with the fuel ratios of ${ }^{89} \mathrm{Sr},{ }^{95} \mathrm{Zr}$, and ${ }^{144} \mathrm{Ce}$ and the assumed radioactive release patterns. An analysis of those assessments showed that their inaccuracy could be explained by the following methodological errors:

- The soil was sampled only to a depth of $5 \mathrm{~cm}$ which did not guarantee the accuracy of the ${ }^{90} \mathrm{Sr}$ measurements because, from 1989 to 1992, strontium was shown to occasionally migrate much deeper (up to $30 \mathrm{~cm}$ ); and

- The entire soil sample (1-2 kg) was used to measure gamma-emitting radionuclides, but a significantly smaller portion of the sample (100-200 g) was used for measuring the ${ }^{90} \mathrm{Sr}$ content, and an even smaller portion was used for measuring the transuranic 
content, thereby causing a large deviation in the measurements results for the samples of various masses due to the significant impact that the fuel particles have on the analytical results.

In 1997, in addition to the routine mandatory monitoring, a special study was conducted to assess the ChEZ soil contamination by the radionuclides of the "fuel component" (the samples for this study were taken in accordance with a specially developed program using a sampling grid of over 1,300 sampling points) (Kashparov 2001a). Beyond that, the major agrochemical properties of the soil that significantly affected the dissolution rate of the fuel particles and radioactive contamination of the vegetation were addressed. Scientists also measured the content of stable chemical elements that were meaningful for assessing migration capabilities of the radionuclides in the soils of various terrains and evaluated various soil sampling techniques regarding their impact on the measurement errors.

The contribution of the fuel particles to the radioactive contamination and the radionuclide leach rates from the fuel particle matrix also were assessed. The results of this study made it possible to (1) generate a number of detailed contamination distribution maps including maps showing the transuranic and ${ }^{90} \mathrm{Sr}$ contamination, (2) assess the rate of destruction of the fuel particles and (3) assess the localized distribution of fuel particles within the ChEZ. Fig. 7 shows the ${ }^{90} \mathrm{Sr}$ contamination map based on the 1997 data. This study made it possible to more accurately estimate the total radionuclide inventory for the fuel component of the ChNPP fallout in the $30 \mathrm{~cm}$ deep soil layer of the ChEZ that, as of 1 January 2000, was as follows (exclusive of the ChNPP industrial site and the radioactive waste disposal sites and the ChNPP Cooling Pond): ${ }^{90} \mathrm{Sr}-810 \mathrm{TBq} ;{ }^{137} \mathrm{Cs}-2,900 \mathrm{TBq} ;{ }^{144} \mathrm{Ce}-0.1 \mathrm{TBq} ;{ }^{154} \mathrm{Eu}-15 \mathrm{TBq} ;{ }^{238} \mathrm{Pu}-8.78 \mathrm{TBq} ;{ }^{239+240} \mathrm{Pu}$ - 15.4 TBq; ${ }^{241} \mathrm{Pu}-564 \mathrm{TBq} ;{ }^{241} \mathrm{Am}-20.6 \mathrm{TBq}$ (Kashparov 2001a). 
The estimates obtained by Kashparov (2001a) were 3-4 times lower than the commonly accepted ones for the total fallout shown in Table $9(0.4-0.5 \%$ of the activity of the radionuclides generated in the reactor by the beginning of the accident). The Kashparov (2001a) estimates made it possible to assess the rate of destruction of the fuel particles. By 2006, a significant part of a previously immobile ${ }^{90} \mathrm{Sr}$ appeared to be leaching from the fuel matrix becoming accessible for plants.

\section{Monitoring of radionuclide migration in soils in various types of terrains}

The monitoring data during the first few post-Chernobyl years and special assessments of radionuclide migration in soils resulted in changes to the Regulations governing soil monitoring. Thirteen soil study sites with various types of terrain were identified for performing regular assessments of soil contamination. These sampling sites were based on the most common types of local terrains as shown in Table 10. The major direction of movement of the radionuclide release following the accident, the types of soils, and the fallout density were also considered for selecting the soil study sites (Fig. 8). At the selected sites, evaluations were made of the contamination density distributions, characteristics of the radionuclide transport from upper to lower soil layers, and the radionuclide transfer factor from soils to plants.

To measure the contamination density, at least 5 evenly distributed soil samples were taken at each study site using an "envelope" pattern, in the corners and center of the square, with the square area being $25 \mathrm{~m}^{2}$. A cylindrical sampler was used with a $5 \mathrm{~cm}$ diameter then could be manually inserted into the soil down to $50 \mathrm{~cm}$ deep. The soil samples were taken from the following layers: $0-5 \mathrm{~cm} ; 5-10 \mathrm{~cm} ; 10-15 \mathrm{~cm}$; and $15-20 \mathrm{~cm}$, followed by compositing the samples taken from the same depth range of each "envelope". In addition, for assessing the 
radionuclides vertical migration into deeper soil layers, each soil study site had one $1.5 \times 0.8 \mathrm{~m}$ prospecting pit. Samples in the boreholes were obtained every $5 \mathrm{~cm}$ down to a $50 \mathrm{~cm}$ depth with necessary precautions to avoid any accidental cross-contamination of the adjacent soil layers to ensure the appropriate quality of the samples. The monitoring data showed that the selected soil study sites provided a fairly complete picture on the major characteristics of the soil contamination.

The amount of ${ }^{137} \mathrm{Cs}$ measured in the soil samples was consistent with the available data on the fallout distribution. The ${ }^{137} \mathrm{Cs}$ content in the $20 \mathrm{~cm}$ soil layer ranged from 71 to $2,600 \mathrm{kBq}$ $\mathrm{m}^{-2}$ at the soil study sites with a relatively high elevation (defined as watershed plains), from 360 to $4,600 \mathrm{kBq} \mathrm{m}^{-2}$ at the soil study sites located above the floodplain terrace of the Pripyat River, and from 3,600 to $38,000 \mathrm{kBq} \mathrm{m}^{-2}$ in the floodplain areas.

Although 25 years have passed since the ChNPP accident, $70-80 \%$ of the remaining ${ }^{137} \mathrm{Cs}$ activity is still detected in the upper $5 \mathrm{~cm}$ soil layer. The ${ }^{137} \mathrm{Cs}$ migration from the upper 5 cm soil layer only exceeds $35 \%$ at LP-5, LP-7, LP-10, and LP-12, which are located above the floodplain terrace. Fig. 9 provides the ${ }^{137} \mathrm{Cs}$ distribution in the various soil layers for selected study sites. The average values obtained during 10 years of the studies show a slight trend towards ${ }^{137} \mathrm{Cs}$ movement into deeper soil layers: its content in the upper soil layer decreased from 0.3 to $2-3 \%$ and similarly increased in the $5-10 \mathrm{~cm}$ deep soil layer. This trend was especially noticeable in the areas with a fairly stable water saturation, i.e., in the hydromorphic soils of the watersheds and above the floodplain areas. Similar trends were observed above the floodplain soil study sites and slightly stronger trends were observed in the floodplain. These patterns are characteristic of ${ }^{137} \mathrm{Cs}$ behavior in the Polesye Region soils known for their high ${ }^{137}$ Cs sorption capabilities. 
The ${ }^{90} \mathrm{Sr}$ distribution had a slightly different pattern. The ${ }^{90} \mathrm{Sr}$ content at the soil study sites ranged as follows for the $20 \mathrm{~cm}$ deep soil layer:

- Watershed plains: $27-550 \mathrm{kBq} \mathrm{m}^{-2}$;

- Above the floodplain terrace: $110-840 \mathrm{kBq} \mathrm{m}^{-2}$; and

- Floodplain: $1,880-7,300 \mathrm{kBq} \mathrm{m}^{-2}$

Due to its higher mobility, ${ }^{90} \mathrm{Sr}$ migrated significantly faster than ${ }^{137} \mathrm{Cs}$ into deeper layers of soil. In addition, its distribution in the surface soil layer can be partially leveled throughout the area due to its lateral surface redistribution. Fig. 10 shows the ${ }^{90} \mathrm{Sr}$ distribution at selected soil study sites.

As of 2009 , over $60-70 \%$ of the precipitated ${ }^{90} \mathrm{Sr}$ moved to deeper soil layers. It should be noted that, during the last few years, especially in $2003-2004$, slightly higher ${ }^{90} \mathrm{Sr}$ values were recorded in the upper $0-5 \mathrm{~cm}$ soil layer, which may have resulted from being released during dissolution of the fallout fuel particles and its more even distribution in the upper soil layer. This more even distribution may have decreased the earlier recorded "spottiness" of the ${ }^{90} \mathrm{Sr}$ contamination.

The decrease of the total ${ }^{90} \mathrm{Sr}$ inventory due to its physical decay and to its possible migration deeper than the monitored $20 \mathrm{~cm}$ soil layer during the last decade was recorded at sites LP-1, LP-3, LP-5, LP-6, LP-7, LP-9, LP-10, LP-11, and LP-13 as shown in Fig. 11. The soil study sites with clay soils (LP-2, LP-4, LP-8, and LP-12) showed an increase in the ${ }^{90} \mathrm{Sr}$ content because clay soils are likely to retain the leached ${ }^{90} \mathrm{Sr}$ in their $20 \mathrm{~cm}$ deep layer. The completed studies did not show any impact the terrain itself might have on the ${ }^{90} \mathrm{Sr}$ transport.

The distribution of transuranic long-lived radionuclides was assessed at the appropriate soil study sites for the $0-10 \mathrm{~cm}$ deep soil layer using the same sampling methods as the one used 
for the other radionuclides. For 2009, the minimum and maximum average concentrations for each of the three terrains are shown in Table 11.

In Fig. 12, the ten year history of observations at the soil study sites shows that the transuranic content, specifically the ${ }^{238} \mathrm{Pu}$ and ${ }^{239+240} \mathrm{Pu}$ content, during that time did not significantly change, and the increase or decrease in the amount of ${ }^{238} \mathrm{Pu}$ and ${ }^{239+240} \mathrm{Pu}$ was within the measurement error. As expected, a more obvious trend of increase was identified for ${ }^{241} \mathrm{Am}$, the accumulation of which results from the decay of ${ }^{241} \mathrm{Pu}$, a relatively short-lived isotope. The distribution of the measured transuranic radionuclides at selected soil study sites is shown in Fig. 13.

Over $80 \%$ of the total ${ }^{238} \mathrm{Pu}$ inventory stayed in the upper $5 \mathrm{~cm}$ soil layer at LP-1, LP-2, LP-3, LP-4, LP-12, LP-13, and LP-6 during the entire 10 -y period. The ${ }^{238} \mathrm{Pu}$ inventory decreased to $70 \%$ or less at LP- 5, LP-7, LP-9, and LP-10. A similar pattern was observed for the distribution of ${ }^{239+240} \mathrm{Pu}$, with over $80 \%$ of the total inventory staying in the upper $5 \mathrm{~cm}$ deep soil layers at LP-1, LP-2, LP-3, LP-4, LP-6, LP-8, and LP-13. At LP-5, LP-7, LP-9, and LP-10, about $30 \%$ of the ${ }^{239+240} \mathrm{Pu}$ moved deeper into the $5-10 \mathrm{~cm}$ soil layer. For LP-5 and LP-7, $46 \%$ of the ${ }^{239+240} \mathrm{Pu}$ migrated out of the $0-5 \mathrm{~cm}$ layer.

The ${ }^{241}$ Am inventory at LP-1, LP-2, LP-3, LP-4, LP-6, LP-7, LP-8, LP-9, LP-10, LP-11, LP-12, and LP-13 ranges from $75 \%$ to $95 \%$ in the upper soil layer and only at LP-5 did the ${ }^{241} \mathrm{Am}$ content decrease to $56 \%$ by 2009 . The depth of the ${ }^{241} \mathrm{Am}$ migration does not appear to depend on the type of the terrain, but rather on the type of soil. For example, the LP-5 site, which differs from the other soil study sites regarding the transuranic activity redistribution, has peat bog soils while the other sites primarily have sod podzol and sandy soils. 
Unfortunately, the utilized Soil Monitoring Regulations (affected by the associated funding and physical capabilities) does not allow for a more detailed assessment of the radionuclide migration in the soils. In 2009 , additional studies of the $50 \mathrm{~cm}$ deep boreholes covering the entire soil profile showed that ${ }^{137} \mathrm{Cs}$ and ${ }^{90} \mathrm{Sr}$ had migrated (in varying amounts) to the deeper soil layers at all soil study sites (Tables 12 and 13, respectively).

Lateral migration of radionuclides appears to be much less significant. The moisture content in the soils plays an important role in the transport and most radionuclides appear to migrate faster in the floodplain areas with high groundwater levels and in areas with peat bog soils. ${ }^{90} \mathrm{Sr}$ migration accelerates in the areas with high levels of organic decomposition, such as at the Red Forest radioactive waste disposal sites.

\section{Airborne contamination in the ChEZ}

The air monitoring in the ChEZ has the following objectives:

- Assess the current status of the airborne contamination to identify exposure doses for the personnel who work in the ChEZ;

- Assess the dynamics and trends of the airborne contamination by systematic studies of the aerosol radionuclide compositions and concentrations;

- Monitor the air in the process facilities and areas of a high occupancy within the ChEZ to assure safe conditions for occupancy and industrial activities in compliance with the regulatory radiation safety and occupational safety requirements;

- Identify sources and causes of airborne contamination and to determine general patterns of the ChNPP fallout in various terrains and under various meteorological conditions; 
- Provide for an effective monitoring and prediction of the airborne contamination in case of inadvertent situations and emergencies at the ChNPP and the ChEZ;

- Monitoring of the environmental impact of the activities associated with radioactive waste management and processing at ChNPP sites, radioactive waste disposal sites, decontamination and disinfection sites, and spent nuclear fuel storage facility construction site (SNFSF-2).

In the pre-Chernobyl period, the airborne contamination within the area of the ChNPP site was monitored at 11 ASKRO monitoring stations and it was actually very low. Table 14 provides some typical monitoring data on the airborne contamination during this time.

As stated earlier, special groups from various research organizations were involved in assessments of the airborne contamination immediately following the ChNPP accident. For example, in June 1986, Teplov et al. (1989) sampled air using portable aspiration systems at the ChNPP industrial site, in the city of Pripyat and in the city of Chernobyl. They also measured radioactive aerosols precipitated on paper napkins exposed within one day. The data on the horizontally and vertically exposed napkins in the city of Pripyat made it possible to assess the rate of the radionuclide precipitation to soils and other surfaces.

As shown in Table 15, the total aerosol activity measured in June 1986 on the roof of the turbine hall of the ChNPP Unit 1 was about $5.6 \mathrm{~Bq} \mathrm{~L}^{-1}$, which was 1,000 times higher than in the city of Chernobyl $\left(0.004 \mathrm{~Bq} \mathrm{~L}^{-1}\right)$ and about 25 times higher than in the city of Pripyat $(0.175 \mathrm{~Bq}$ $\left.\mathrm{L}^{-1}\right)$.

From 9 to 26 July 1986, Teplov et al. (1989) performed their first measurements of the volume activity, radionuclide composition, mass concentration, and particle size of the radioactive aerosols at the ChNPP Reactor Unit 1 . The aerosols were sampled using analytical 
aerosol filters and cascade impactors, and the samples were measured using gamma and alpha spectrometers. All the instrumentation had been certified by the Emergency Group of the USSR State Committee on Standards that worked on-site during the ChNPP accident mitigation period.

The studies showed that the volume activity of the aerosols measured by beta radiometry and gamma spectrometry ranged from 0.044 to $3.66 \mathrm{~Bq} \mathrm{~L}^{-1}$. The composition of the gammaemitting radionuclides in the aerosol samples is provided in Table 16. The activity of the longlived alpha-emitting radionuclides in the air of the ChNPP industrial site ranged from 0.00035 to $0.0099 \mathrm{~Bq} \mathrm{~L}^{-1}$. The average integral distribution of the particle activity in various particle sizes is provided in Table 17.

From 11 June 1986 to 22 September 1986, systematic airborne contamination monitoring was performed in the city of Chernobyl and the total sample volume ranged from 500 to 1,500 $\mathrm{m}^{3}$. The measured total activity varied within approximately one order of magnitude, from (0.0037-0.0074) $\mathrm{Bq} \mathrm{L}^{-1}$ up to (0.037-0.074) $\mathrm{Bq} \mathrm{L}^{-1}$. In dry weather some fairly severe spikes of activity would occur, while after rains the activity tended to decrease (Teplov et al. 1989).

In 1987, the airborne contamination monitoring became routine and systematic, with the original pre-Chernobyl network of ChNPP aspiration sampling stations being used for sampling. In addition, in 1987-1988, aerodynamic aspiration free sampling devices were widely used. The aspiration free sampling device was a gauze cone pulled on a rotating wire frame installed on a rod fixed on the ground. The axis of the gauze cone was placed horizontally to the rod at a $90^{\circ}$ angle $1.5 \mathrm{~m}$ above the ground surface (Industrial Standard 1985). Such sampling devices were frequently used to assess deposition of radionuclides near roads.

The aspiration sampling network gradually expanded and by early 1989, the monitoring network of the Health Physics Division included 78 air monitoring stations and 42 fallout 
monitoring stations. The radionuclide composition of the aerosols from 1987 to 1989 is provided in Table 18 and the average annual concentrations of the total airborne activity in 1987 and 1988 are shown in Table 19.

During the first 4-5 years following the ChNPP accident, the airborne contamination gradually decreased as shown in Table 20. However, depending on the meteorological conditions and intensity of the decontamination activities, the average monthly airborne contamination concentrations fluctuated fairly significantly. The year 1991 was a "dry" year when up to 200 grassland and forest fires were recorded in the ChEZ, and was especially remarkable in this respect.

In 1993 (Ivanov 1994), the radionuclide concentrations in the busiest places of the ChNPP proximity zone [ORU-750, Petroleum Depot (Neftebaza), Water Pump Station (BNS), and the city of Pripyat], ranged as follows: ${ }^{137} \mathrm{Cs}$ : from $1.96 \times 10^{-7}$ to $7.03 \times 10^{-6} \mathrm{~Bq} \mathrm{~L}^{-1},{ }^{90} \mathrm{Sr}$ : from $3.29 \times 10^{-7}$ to $2.14 \times 10^{-6} \mathrm{~Bq} \mathrm{~L}^{-1},{ }^{238,239,240} \mathrm{Pu}$ : from $1.0 \times 10^{-9}$ to $3.9 \times 10^{-8} \mathrm{~Bq} \mathrm{~L}^{-1}$. The control level concentration was $18.5 \times 10^{-6} \mathrm{~Bq} \mathrm{~L}^{-1}$ for the total of all radionuclides; therefore, the control level was not exceeded. In the ChNPP "remote" area, including residence areas (Zeleny Mys, Chernobyl, and Dityatki), the ${ }^{137} \mathrm{Cs}$ concentration ranged from $4.8 \times 10^{-9}$ to $1.9 \times 10^{-7} \mathrm{~Bq} \mathrm{~L}^{-}$ ${ }^{1}$, which was well below the control level $1.8 \times 10^{-6} \mathrm{~Bq} \mathrm{~L}^{-1}$.

Currently, the air monitoring within the ChEZ is performed in accordance with the Air Monitoring Regulations. For air monitoring purposes, the ChEZ was divided into two areas: (1) the "proximity" area, with a radius of $5 \mathrm{~km}$ around the ChNPP and (2) the "remote" area ranging from $5 \mathrm{~km}$ to $30 \mathrm{~km}$ from the ChNPP.

According to the Air Monitoring Regulations (DSNVP EcoCenter 2009), the following measurements are performed in the ChEZ: 
- Airborne radionuclide concentrations at four monitoring stations in the proximity area and nine monitoring stations in the remote area;

- ${ }^{137} \mathrm{Cs}$ atmospheric deposition at 26 monitoring stations; and

- Airborne radionuclide concentrations at the ChEZ operational facilities.

The airborne radionuclide concentrations in the "proximity" area are measured at the following air monitoring stations:

- ChNPP open distribution devices (ORU-750);

- Petroleum depot (Neftebaza);

- City of Pripyat (Health Physics Lab); and

- ChNPP water pump station (BNS-3);

Measurements in the "remote" area were performed at the ASKRO monitoring stations using specially designed fixed filter ventilation devices. The same devices were used in the ChEZ personnel residence areas in the city of Chernobyl and the village of Dityatki. For sampling, the air was continuously pumped through Petryanov's filters (type FPP-15-1.5) with the filters being replaced every $5-7 \mathrm{~d}$.

The airborne contamination at the $\mathrm{ChEZ}$ industrial facilities [Buryakovka radioactive waste disposal site and the Area of Preliminary Decontamination of Radioactively Contaminated Materials (UPD RZM)] was typically sampled four times a month using a mobile aspiration device. At the ChNPP site, the airborne contamination was sampled once a month. Each aerosol sampled by the Petryanov's filter was analyzed using a laboratory gamma spectrometer. The ${ }^{90} \mathrm{Sr}$ and alpha-emitting radionuclides $\left({ }^{238} \mathrm{Pu},{ }^{239+240} \mathrm{Pu}\right)$ in the aerosol samples were measured using radiochemistry methods. 
For sampling the atmospheric fallout, specially designed pads installed $1 \mathrm{~m}$ above ground level were used. The pads were covered with filter paper with the density of $85 \mathrm{~g} \mathrm{~m}^{-2}$ to trap the contaminants. The exposure time for the pads ranged from 10 to $20 \mathrm{~d}$. The fallout samples at each monitoring station were taken twice a month and analyzed using gamma spectroscopy in a lab. The concentrations of ${ }^{90} \mathrm{Sr}$ and plutonium isotopes were measured using radiochemical methods in a sample composited on a quarterly basis.

The sampling of the airborne contamination and ${ }^{137} \mathrm{Cs}$ fallout was performed according to the applicable sampling procedures of the GSNPP EcoCenter. The radionuclide concentrations measurements were performed in accordance with applicable and approved procedures and methodologies. The metrological verification and calibration of the radionuclide measurements instrumentation, as well as its required regular maintenance were strictly enforced.

\section{Airborne contamination results at the ASKRO monitoring stations}

Currently, the airborne radioactive contamination within the ChEZ significantly depends on the following factors: physical and chemical forms of the fallout ("condensation" ${ }^{137} \mathrm{Cs}$ or "fuel" particles), changes in the soil conditions, and specific meteorological conditions during sampling. The airborne radionuclide concentrations can also be significantly affected by technogenic factors, specifically:

- Routine and random release from the ChNPP site including the Shelter Facility (monitoring locations at the ChNPP industrial site during operations of the ChNPP reactors);

- Operational activities associated with the radioactive waste management;

- Industrial and associated activities in the ChEZ; 
- Construction activities associated with new construction; and

- Vehicular traffic and status of the transportation infrastructure.

The impact of fires on the airborne contamination mostly depends on localization of the fire source and a scale of the fire. According to Kashparov (2001b), fires were not found to cause a significant spread of the airborne contamination.

Table 21 shows the average airborne ${ }^{137} \mathrm{Cs}$ concentrations in $1987-2009$ as recorded at fixed air monitoring stations with continuous air sampling. The monitoring results show that the airborne contamination was significant the first few years following the ChNPP accident, but by 2000, it had greatly decreased at most sites to the current, fairly stable levels (Fig. 14). The large increase in the airborne radionuclides concentration at the monitoring stations Buryakovka, Benevka, Mashevo, and Chistogalovka in the year of 2000 can be explained by the following three factors: 1) meteorological conditions, i.e., a very dry and hot summer, strong and occasionally squally winds, 2) intensification of industrial activities, i.e., construction activities and, consequently, earth moving associated with construction of the Vektor radioactive waste management facility, and 3) grassland wild fires.

The highest airborne ${ }^{137} \mathrm{Cs}$ concentration values were recorded within the ChNPP industrial site at ORU-750 and the petroleum depot. Slightly lower values were recorded at the BNS-3 water pump station and the city of Pripyat monitoring stations. Relatively high airborne ${ }^{137} \mathrm{Cs}$ concentrations were recorded in locations with a high surface contamination of the soil (Table 7): Zimovitsche, Kopachi, and Mashevo, as well as at the construction sites with intense traffic: the Buryakovka radioactive waste disposal site and Benevka.

In most cases, the average ${ }^{137} \mathrm{Cs}$ concentrations during warm seasons appear to exceed those in cold seasons by factors of 1.5-2. During the last decade, the airborne contamination in 
the ChEZ has been primarily affected by meteorological conditions. In rainy and snowy years, with frequent and heavy precipitation or long periods of a high humidity and fog, the contaminated areas become saturated with water, thereby reducing wind transport of the radionuclides. In dry years with little snow, the wind transfer of the radionuclides intensifies causing an increase in the airborne contamination. In recent years, the administrative control airborne contamination levels have rarely been exceeded (Kireev et al. 2007).

Since the accident, the radionuclide composition of the airborne contamination has significantly changed (Table 22); specifically, by the mid-1990's, ${ }^{134} \mathrm{Cs}$, due to its physical decay, only contributed a few percent to the total activity and by 2008 it was not longer detectable. The ${ }^{241}$ Am content has increased over the years, as expected. The major contributors to the airborne contamination remain ${ }^{137} \mathrm{Cs}$ (up to $70 \%$ ) and ${ }^{90} \mathrm{Sr}$ (up to $20 \%$ ). Due to its physical decay, the ${ }^{241} \mathrm{Pu}$ content has decreased from $10-15 \%$ in $1995-2001$ to $6-7 \%$ in the last few years.

\section{Atmospheric deposition monitoring results}

Pads covered with filter paper installed $1 \mathrm{~m}$ above the ground level were used to sample the fallout. In most cases, the fallout sampling was performed at all ASKRO monitoring stations, as well as in the points of the $5 \mathrm{~km}$ ChNPP reference grid with a radial azimuth based configuration. The exposure of the pads ranged from 10-20 d. The results of the $1993-1996{ }^{137} \mathrm{Cs}$ concentration measurements in the fallout are provided in Table 23 and it shows that the fallout activity primarily depends on the distance from the epicenter at the ChNPP. Fairly high ${ }^{137} \mathrm{Cs}$ concentrations were recorded in all directions within the $5 \mathrm{~km}$ radius. The measured values were consistent with seasonal frequencies of wind directions, with the east sector being significantly lower because the wind blows from this sector towards the ChNPP site a majority of the time. At 
fairly long distances from the ChNPP site, the ${ }^{137} \mathrm{Cs}$ concentration decreases and the dependence on the wind direction decreases as well.

For the last few years in the "proximity" area, the intensity of the ${ }^{137} \mathrm{Cs}$ fallout ranged from 0.04 to $22 \mathrm{~Bq}\left(\mathrm{~m}^{2} \mathrm{~d}\right)^{-1}$. Relatively high ${ }^{137} \mathrm{Cs}$ concentrations were recorded within the ChNPP industrial site (Kompleksny radioactive materials disposal site). A high intensity of the ${ }^{137} \mathrm{Cs}$ fallout was also observed at the monitoring stations $3 \mathrm{~km}$ southwest and $1 \mathrm{~km}$ south of the ChNPP site due to their close location to the ChNPP site and due to the prominent wind in the region (primarily north and northeast winds). The ${ }^{137} \mathrm{Cs}$ fallout intensity decreases as a function of distance from the ChNPP site and it ranges from 0.04 to $14 \mathrm{~Bq}\left(\mathrm{~m}^{2} \mathrm{~d}\right)^{-1}$ at the remote monitoring stations. The ${ }^{137} \mathrm{Cs}$ fallout intensity ranges from 0.04 to $0.81 \mathrm{~Bq}\left(\mathrm{~m}^{2} \mathrm{~d}\right)^{-1}$ in the city of Chernobyl. The characteristics of the ${ }^{137} \mathrm{Cs}$ fallout at the $\mathrm{ChEZ}$ monitoring stations are given in Table 24.

One of the mandatory elements of the airborne contamination monitoring program is air monitoring at the major $\mathrm{ChEZ}$ industrial facilities that are considered to be potential sources of radioactive contamination. Specifically, the Buryakovka radioactive waste disposal site the area for preliminary decontamination of contaminated materials (UPD RZM), as well as the ChNPP facilities, such as Shelter Facility, and ChNPP Reactor Units that are currently being decommissioned. The average airborne contamination monitoring results for the ChEZ industrial facilities combined are provided in Table 25 . Recently, the airborne volume activity at the New Safe Confinement (NSC) construction site was as follows: ${ }^{239+240} \mathrm{Pu}: 0.0000514 ;{ }^{238} \mathrm{Pu}$ : 0.0000215; and ${ }^{241} \mathrm{Am}: 0.0000971 \mathrm{~Bq} \mathrm{~m}^{-3}$ (sampled on 7 July 2009).

The total ChNPP operations related radioactive releases, including operational emissions from the Shelter Facility, are not significant in comparison with the ChNPP accident related 
contamination. For 2000-2007, the ChNPP Reactor Units 1 and 2 stack emissions are shown in Table 26.

Fluctuations of the airborne contamination within a year primarily result from meteorological conditions and, consequently, the intensity of the deposition processes. At a number of monitoring stations anthropogenic activities affect these fluctuations. For the last few years, the monitoring stations near the village of Buryakovka and the village of Benevka have been recording abnormally high airborne radionuclide concentrations due to the active construction of the New Safe Confinement for the ChNPP Shelter Facility. However, in general, current industrial activities do not make a considerable contribution to the airborne contamination, in comparison with the post-Chernobyl contamination, changing only local dynamic values.

The atmospheric monitoring occasionally makes it possible to witness an impact of biological processes on the airborne contamination. For example, in May 2009, almost all monitoring stations recorded a trend of a gradual increase of the ${ }^{137}$ Cs volume activity in the air, which might have been caused by pine blossom and pine pollen accumulation in the air. Considering the fact that the pine pollen activity depends on the soil contamination in the area where the pine trees grow, the pine pollen concentrations ranged from $34-425 \mathrm{kBq} \mathrm{kg}^{-1}$. The highest airborne contamination peak was recorded in the air samples from May $18^{\text {th }}$ to the $26^{\text {th }}$. During this time the amount of ${ }^{137} \mathrm{Cs}$ fallout also was significantly higher than during the previous months. However, as soon as a rain event occurred (26-31 May), the ${ }^{137} \mathrm{Cs}$ concentration started a drastic decrease.

\section{Aqueous radiological monitoring results}


The hydrographic network in the ChEZ is well developed. The total area of water reservoirs and swamps contributes to $11 \%$ of its entire territory. The major water artery in the ChEZ is the Pripyat River that crosses the ChEZ from northwest to southeast flowing into the Kiev Water Reservoir. The major tributary of the Pripyat River within the ChEZ is the Uzh River that flows in the southern part of the ChEZ and flows into the Pripyat River south of the city of Chernobyl. The ChEZ covers about $15 \%$ of the water intake area for the Uzh River, starting from its downstream part near the village of Polesskoe to the estuary. In this area, minor rivers, such as the Grezlya River and the Ilya River, flow into the Uzh River from its left bank and the Bober River and the Veresnya River flow into the Uzh River from its right bank (Vishnevsky 2001). The water intake for the Sakhan River that flows into the Pripyat River near the village of Novoshepelichi and the water intake for the Glinitsa River that flows into the Pripyat River near the village of Lelev are located exclusively in the ChEZ on the right bank of the Pripyat River.

The Exclusion and Mandatory Resettlement Zone contains about $280 \mathrm{~km}^{2}$ of earlier reclaimed lands. The farmland reclamation in this region had started long before the 1986 accident due to its oversaturation with water resulting from the excess of precipitation over evaporation, insufficient sloping, shallow groundwater, and a large number of small depressions in the terrain. To remove excess water, the existing streams were dredged and widened and a network of drainage canals was constructed. In addition, swampy areas were drained systematically and selectively with an underground water collection network. Therefore, prior to the ChNPP accident, this area had a well-balanced regulated hydrologic system established for agricultural needs. Significant annual and seasonal fluctuations in the groundwater level were observed during operation of the drainage systems, with the minimum water level annually recorded at the end of winter, and the spring increase in the water level recorded between the end 
of March and the middle of May. The amplitude of water level fluctuations associated with rainfall ranged from 0.5-0.7 $\mathrm{m}$ (Shestopalov et al. 2001).

The reclamation systems located in the ChEZ are part of the system of the Uzh River and its tributaries, Nesvich River and Sakhan River, and a few minor streams. There is also another reclamation system based on an old polder on the left bank near the villages of Usov, Mashevo, Krasno, and Zimovische. Apart from precipitation, that area is periodically flooded by moderately contaminated water from Belarus. To comply with the fire prevention requirements, that water bypasses the Pogonyansky Canal, its natural water collector. Since 1992, it has been diverted to humidify peat and wooded areas in Belarus and then it enters the heavily contaminated area of the Krasnyansky polder. At the end of 1991, the bulk of that water was diverted to the system of the Nesvich and Braginka rivers. The excess water from the polder (primarily in high water periods) is discharged through a passage in Levee 7 to the Pripyat River.

The ChEZ hydrologic system also includes stagnant and nearly stagnant bodies of water, such as the Novoshepelichsky stream, the Semokhodsky and Pripyatsky backwater ponds that were cut off from the Pripyat River after the 1986 accident, the Azbuchin Lake on the right bank and minor water reservoirs in the left bank floodplain. In 1992, a levee was built on the Pripyat River to protect the cut-off Murovka and Krasnensky streams, Glubokoe Lake, Vershina Lake, and other minor water reservoirs from flooding. Some of these cut-off water reservoirs are connected by a drainage canal and the excess water from the drainage canal is pumped to the polder (hereinafter referred to as the Krasnyansky polder) near the villages of Krasno and Zimovische.

The ChNPP Cooling Pond is located in the immediate proximity of the ChNPP, along the right bank of the Pripyat River. The Cooling Pond is a man-made water reservoir that is 
considered to be one of the most important elements of the ChNPP operations. The water level in the Cooling Pond is constantly maintained at $6 \mathrm{~m}$ higher than in the Pripyat River, resulting in a continuous water transfer to the Pripyat River via surface flow (North and South Drainage Canals - River Glinitsa), continuous seepage through the bottom of the pond and the levee, and groundwater.

The radionuclide transport with aqueous flows within and beyond the contaminated territory is of great significance. During the first few days following the ChNPP accident, radionuclides were mostly transferred through the atmosphere, but after that the aqueous migration of them became predominant. Currently, the aqueous transport is considered to be the main contributor to the radionuclide transport outside the ChEZ.

\section{Surface water monitoring organizations}

The Institute of Biophysics of the USSR Ministry of Health, the Radiological Laboratory of the Sanitary and Epidemiological Station of the Ukrainian Socialist Republic USSR (KIOKG) and the ChNPP External Health Physics Laboratory performed the radiation assessment of the area prior to startup of the first ChNPP reactor. This assessment started in June 1977 and finished in September 1977 when the first ChNPP reactor was put into operation. The total activity of the water at that time ranged from $3.7 \times 10^{-4}$ to $2.8 \times 10^{-3} \mathrm{~Bq} \mathrm{~m}^{-3}$, with the concentrations of ${ }^{137} \mathrm{Cs}$ and ${ }^{90} \mathrm{Sr}$ being equal to approximately $8 \times 10^{-6} \mathrm{~Bq} \mathrm{~m}^{-3}$.

According to the recommendations of the USSR Ministry of Health (Marey and Zykova 1980), the radiation monitoring of aquatic objects affected by the ChNPP was performed in 13 monitoring stations where the concentrations in water, bottom deposits, and aquatic biota was 
measured. The concentrations of the main gamma-emitting radionuclides in various components of the Cooling Pond ecosystem prior to the ChNPP accident are shown in Table 27.

In 1982, an incident at the ChNPP (melting of one fuel canal in Reactor Unit 1) resulted in a radioactive release that caused an increase in the Cooling Pond water activity that reached the following values: ${ }^{134} \mathrm{Cs}: 0.011-3.7 \mathrm{~Bq} \mathrm{~L}^{-1} ;{ }^{137} \mathrm{Cs}: 0.007-0.044 \mathrm{~Bq} \mathrm{~L}^{-1} ;{ }^{60} \mathrm{Co}: 3.7-22.2 \times 10^{-4} \mathrm{~Bq} \mathrm{~L}^{-1}$. The total concentration ranged from 1.1-10 $\mathrm{kBq} \mathrm{L}^{-1}$. The distribution of the gamma-emitting radionuclides remained relatively constant during a short period of time in late summer and early fall of 1982 , but the activity reached a few hundred $\mathrm{kBq} \mathrm{L}^{-1}$ in the ChNPP discharge canal (Kazakov 1995).

The 1986 ChNPP accident resulted in a very high contamination of the aquatic media of the ChEZ. During the first few days following the accident, the major sources of contamination for the surface water were associated with the aerosol fallout resulting in an increase of concentrations of such radionuclides as ${ }^{131} \mathrm{I},{ }^{140} \mathrm{Ba},{ }^{95} \mathrm{Zr},{ }^{106} \mathrm{Ru}$ and cesium isotopes as shown in Table 28 (Ignatenko et al. 1989). Specifically, on 2 May 1986, the ${ }^{131}$ I concentration in the Pripyat River reached 4,440 $\mathrm{Bq} \mathrm{L}^{-1}$, and the ${ }^{140} \mathrm{Ba}$ concentration reached $1,400 \mathrm{~Bq} \mathrm{~L}{ }^{-1}$. During the first months following the accident, the major objective of the surface water contamination studies was to assess potential radionuclide transport with aqueous flows and estimate the exposure doses for the population resulting from the contamination of the major waterways of the country.

According to Teplov et al. (1989), the water contamination within the ChNPP site in June 1986 was as shown in Table 29. The total activity measured in the Cooling Pond water was higher than even the water used for decontamination at the Vehicle Decontamination Facility 
that performed decontamination of the vehicles involved in the ChNPP accident mitigation activities.

During the period immediately following the ChNPP accident, the first and foremost objective of the surface water monitoring was to assess the potential transport of the contaminated water outside the ChEZ and its contribution to the potential radiation exposure of the country's population. Another more narrow and practical task was to determine whether it would be possible to recover operations at the ChNPP and use the contaminated water of the Cooling Pond for cooling the turbine condensers of the intact ChNPP reactors. According to the initial data shown in Table 30, the total radionuclide inventory in the Cooling Pond water immediately following the accident was extremely high (Kazakov 1995). At that period of time, $70-99 \%$ of such isotopes as ${ }^{141} \mathrm{Ce},{ }^{144} \mathrm{Ce},{ }^{103} \mathrm{Ru},{ }^{95} \mathrm{Zr}$, and ${ }^{95} \mathrm{Nb}$ were sorbed by the suspended matter in the water and $90-100 \%$ of such isotopes as ${ }^{140} \mathrm{Ba},{ }^{90} \mathrm{Sr},{ }^{134} \mathrm{Cs}$, and ${ }^{137} \mathrm{Cs}$ were dissolved in the water. The radioactive contamination of the Cooling Pond was primarily caused by the fallout and the amount that precipitated on the ChNPP Cooling Pond surface during the first days after the accident was estimated to be $13.2 \mathrm{PBq}$ (Egorov et al. 1988). There was another contributor to the Cooling Pond water contamination during the first days following the accident, contaminated water was discharged to the ChNPP Cooling Pond from the technological systems of the damaged reactor. Subsequently, the major contributor to the ChNPP Cooling Pond water contamination was a surface aqueous flow from the contaminated areas and radionuclide wind transfer. About a month after the accident (end of May 1986), approximately 95\% of all the radionuclides that entered the Cooling Pond after the accident consolidated in the bottom deposits, increasing the silt contamination by a few orders of magnitude. 
By September 1986, due to the decay of short-lived radionuclides, the specific activity of the Cooling Pond water and bottom deposits continued to decrease but still maintained between $37-1,000 \mathrm{~Bq} \mathrm{~L}^{-1}$. The percent contribution of each radionuclide into the total activity of the water at that time was as follows: ${ }^{141} \mathrm{Ce}-2.5 \% ;{ }^{144} \mathrm{Ce}-29 \% ;{ }^{103} \mathrm{Ru}-2.3 \% ;{ }^{96} \mathrm{Zr}-18 \% ;{ }^{95} \mathrm{Nb}-23 \%$; ${ }^{134} \mathrm{Cs}-7.3 \% ;{ }^{137} \mathrm{Cs}-17 \%$. The activity of several isotopes, such as ${ }^{131} \mathrm{I},{ }^{140} \mathrm{Ba}$, and ${ }^{140} \mathrm{La}$, decreased by a few orders of magnitude and they were no longer measurable in the environment. By that time, ${ }^{106} \mathrm{Ru}$ was detected in the samples that earlier had been masked from being detected in the spectra by other gamma emitters. The ${ }^{106} \mathrm{Ru}$ concentration in the components of the Cooling Pond in September-October 1986 ranged from 0.15 to $0.25 \%$ of the ${ }^{103}$ Ru activity.

The first studies of the impact the ChNPP accident had on the Cooling Pond showed that complex processes of radionuclide redistribution and migration were in progress in the Cooling Pond. During the initial period of time after the accident, the major processes were a physical decay of the short-lived isotopes, precipitation and sorption of some of the radionuclides by the suspended matter and biological components, and precipitation onto the bottom deposits. The estimates of natural decontamination processes obtained during the initial period of time after the ChNPP accident are shown in Table 31.

The water contamination and natural decontamination assessments provided a basis for a possibility to use this water in the ChNPP process cycle and resume operation of ChNPP Reactor Units One and Two, followed by Unit Three. The studies of the ChEZ water reservoirs immediately following the ChNPP accident made it possible to predict the potential contamination of the major waterway of Ukraine (the Dnieper River) and to perform some preventive actions.

According to the Ukrainian Research Hydrometeorlogical Institute and the Health Physics Division of the Pripyat Scientific and Production Association, the total amount of ${ }^{90} \mathrm{Sr}$ 
and ${ }^{137} \mathrm{Cs}$ released into the Kiev Water Reservoir by the Pripyat and Dnieper rivers during the first few years following the ChNPP accident was as shown in Table 32.

To minimize the radionuclide transfer into the Kiev Water Reservoir and their subsequent migration to the downstream water reservoirs of the Dnieper Cascade, levees and earth walls were built to enclose the Pripyat River basin. In addition, filtering and solid dams were built to cutoff the existing water reclamation canals and minor rivers. A few bottom pits were dug in the estuary of the Pripyat River, and some other precautionary measures were taken. The subsequent analysis of the effectiveness of these measures showed that not all of them had proved to be successful. These newly built water remediation structures only served their functions well in the summer and fall of 1986. However, during the flood season of 1987, the effectiveness of most of them appeared to be fairly low (Voytsekhovich et al. 1997).

Since 1987, aquatic monitoring became systematic and it includes the following objectives:

- Study the hydrological system and monitor the radiation status of the various aquatic components;

- Establish correlations between the hydrological mode and the radiation status of the surface water;

- Assess the radionuclide transfer into the Kiev Water Reservoir and identify contributions of the major sources of contamination of the Pripyat River and the Kiev Water Reservoir; and

- Evaluate the impact of the water remediation structures on the hydrological mode and radiation status of the aqueous objects; identify the impact of the aqueous flows on the water remediation structures to assure reliability of these structures. 
By 1987-1989, the Kombinat Health Physics Division (subsequently reorganized into the Pripyat SPA) acquired all necessary facilities and equipment to perform a full-scale monitoring of the aqueous objects, such as a number of surface water sampling stations, boats, sampling tools and equipment, radiochemistry and spectrometry laboratory, and computing capabilities. The radiation monitoring data were systematically processed and forwarded to all organizations who had requested them. The monitoring activities were performed according to the Monitoring Regulations approved by the Pripyat SPA SIE Health Physics Division and also according to a number of specially developed programs associated with ChNPP accident mitigation activities.

The required surface water monitoring included: the Pripyat River and its tributaries, northwestern part of the Kiev Water Reservoir, ChNPP Cooling Pond and its seepage waterways, feed and discharge canals of the ChNPP Reactor Units 1 and 2, discharge canal of the ChNPP Phase 3 (confined water reservoir), backwater ponds and lakes cutoff from the Pripyat River in its right bank floodplain, as well as aqueous objects in the vicinity of the water remediation structures in the left bank floodplain (Krasnyansky polder). In total, 22 major and minor streams and 10 stagnant and nearly stagnant water reservoirs are continuously monitored. The monitoring is performed at 36 control and water measuring stations that are the most representative for the hydrological mode and the radiation status of the aqueous objects. The goal of the monitoring is to record the radionuclide intake and release with the surface water and the effectiveness of the water remediation structures.

Table 33 shows the monitoring data on changes in the water contamination in the ChEZ major bodies of water in 1992-2009. The changes in radionuclide concentrations in the Pripyat River water and their transport depending on the water flow rate during the period of measurements are shown in Fig. 15. Table 34 illustrates the role of surface water in the 
radioactive contamination of the Dnieper River by describing dynamic characteristics of the aqueous transfer of the most mobile and biologically significant isotope, ${ }^{90} \mathrm{Sr}$, during the period of 1999-2009.

The ${ }^{90} \mathrm{Sr}$ transfer by the Uzh River in 2007-2009 averaged approximately $0.08 \mathrm{TBq}$, and the ${ }^{90} \mathrm{Sr}$ transfer by the Braginka River was $0.32 \mathrm{TBq}$. A total of $1.72-1.77 \mathrm{TBq}$ of the ${ }^{90} \mathrm{Sr}$ activity was transferred to the Kiev Water Reservoir by the surface water. The contributions of the Pripyat River, the Uzh River, and the Braginka River into this transfer are approximately $75 \%, 7 \%$, and $18 \%$, respectively. The Krasnyansky polder with its water reclamation system contributed to $31 \%$ of the total ${ }^{90} \mathrm{Sr}$ transfer outside the ChEZ $(0.28 \mathrm{TBq})$. The contribution of such sources as the Sakhan River and the ChNPP Cooling Pond seepage flows has not practically changed during the last five years supporting about $2-4 \%$ of the total ${ }^{90} \mathrm{Sr}$ transfer by the Pripyat River.

Currently, the maximum ${ }^{137} \mathrm{Cs}$ specific activity values are recorded in the discharge canal of the ChNPP Phase 3 (up to $100 \mathrm{kBq} \mathrm{m}^{-3}$ ), Azbuchin Lake, and Glubokoe Lake, as well as in the water reservoir in the Rodvino district and the left bank polder (the $4-11 \mathrm{kBq} \mathrm{m}^{-3}$ level). The ${ }^{90} \mathrm{Sr}$ concentrations in the water of the Pripyat River when the Pripyat River enters the ChEZ has recently been fairly low (around $20-30 \mathrm{kBq} \mathrm{m}^{-3}$ ). In years with insignificant flooding of the floodplains in the Ukrainian and Belorussian territories, a decrease of the radionuclide transfer with the aqueous flows occurs. The ${ }^{90} \mathrm{Sr}$ content in the Pripyat River in the city of Chernobyl is about $100 \mathrm{kBq} \mathrm{m}^{-3}$. The maximum ${ }^{90} \mathrm{Sr}$ values (up to $360 \mathrm{kBq} \mathrm{m}^{-3}$ ) were recorded during the periods of ice formation and ice jams (January and December) and in the fall during the low water season. The minimum ${ }^{90} \mathrm{Sr}$ content (up to $50 \mathrm{kBq} \mathrm{m}^{-3}$ ) was usually recorded with the river 
flooding peaks and flash flooding. The lowest ${ }^{90} \mathrm{Sr}$ values for the entire monitoring period were recorded in 2009 .

The transuranics content is monitored in the Pripyat River, ChNPP Cooling Pond, Pripyatsky backwater pond, Semikhodsky backwater pond, Azbychin Lake, discharge canal of the ChNPP Phase 3, left bank polder, and Glubokoe Lake. The highest transuranic concentrations were recorded in the Semikhodsky and Pripyatsky backwater ponds, as well as in the left bank polder: ${ }^{241} \mathrm{Am} 0.2-7.9 \mathrm{~Bq} \mathrm{~m}{ }^{-3}$ and $0.5-5.4 \mathrm{~Bq} \mathrm{~m}^{-3}$ for all of the plutonium isotopes. The transuranic concentrations in the Pripyat River are only a few tenths of a $\mathrm{Bq} \mathrm{m}^{-3}$, which is practically considered the minimum detectable level, even with the current analytical capabilities.

The long-term monitoring conducted shows that the surface water is the major route for the radionuclide transport outside the ChEZ and for radionuclide redistribution within the ChEZ. The integral ${ }^{90} \mathrm{Sr}$ transport outside the ChEZ in $1986-2009$ reached $170.5 \mathrm{TBq}$ and the ${ }^{137} \mathrm{Cs}$ transport reached $130.3 \mathrm{TBq}$. In general, the ChEZ generates about $70 \%$ of the ${ }^{90} \mathrm{Sr}$ activity and about $10 \%$ of the ${ }^{137} \mathrm{Cs}$ activity transferred to the Dnieper River.

The radiation status of the ChEZ rivers, including the Pripyat River, depends on an annual water level, phases of the aqueous mode, and condition of the water remediation structures. With severe floods (as in, for example, 1999), about $90 \%$ of the ${ }^{90} \mathrm{Sr}$ transfer is associated with its washout from the floodplain areas and the so called transit component that is formed in the upper parts of the Pripyat River basin. With medium to no flooding (when the Pripyat River floodplain is not flooded, which has been the case for the last five years), the major source of the ${ }^{90} \mathrm{Sr}$ transfer is associated with the transit inflows. In a low water period, the major 
source of contamination is associated with the underground water entering the Pripyat River. The underground water contribution into the ${ }^{90} \mathrm{Sr}$ transport in low water periods reaches $60-65 \%$.

The most heavily contaminated water reservoirs in the ChEZ are Azbuchin Lake and Glubokoe Lake. Another one is the water reservoir in the Rodvino District near the village of Kopachi because these bodies of water, unlike the ChNPP Cooling Pond, are not provided with an artificial water exchange. These bodies of water are located in heavily contaminated areas, a few kilometers way from the ChNPP. The water and silt bottom deposits of these reservoirs are primarily contaminated with the "fuel" component of the ChNPP release. Due to the decomposition and leaching of the radionuclides from the fuel particles, these water reservoirs had high ${ }^{90} \mathrm{Sr}$ contamination levels, ranging from 100 to $200 \mathrm{kBq} \mathrm{m}^{-3}$.

The radioactive washout into the rivers with the surface runoffs in the watershed is the key factor for the contaminant transport to large areas outside the ChEZ. Nevertheless, an annual decrease in the radionuclide content due to the natural washout from the surface of the contaminated soils did not appear to be significant, from a few tenths to $1 \%$ of the total radioactive inventory in the basins of the rivers. At most Ukrainian watersheds where the soils are primarily comprised of mineral particles, the ${ }^{137} \mathrm{Cs}$ washout factors were $1-5 \times 10^{-2} \mathrm{~m}^{-1}$. The

${ }^{90} \mathrm{Sr}$ washout factors from the same areas were $3-5$ times higher than for ${ }^{137} \mathrm{Cs}$, but did not exceed the upper limit of $10^{-1} \mathrm{~m}^{-1}$ either (Voytsekhovich et al. 1997; Bulgakov et al. 2001). Therefore, during the 20-y period, naturally occurring melting snow and rainfall did not significantly decrease the radionuclide inventory in the contaminated watershed areas.

\section{Radiological Status of Groundwater in the ChEZ}

The geological media and especially the groundwater are very important ecological components of the region. The active water exchange zone where the groundwater may get 
contaminated within the ChEZ includes two aquifers associated with Quaternary and Eocene deposits and separated by the poorly permeable Kiev chalky clays.

The aquifer in the Quaternary deposits can be found above the entire floodplain terrace and the floodplain of the Pripyat River. The Neogene Quaternary deposits that contain the first unconfined aquifer are represented by several layers of deposits with different permeability and sorption properties significantly affecting the groundwater movement and migration of the contaminants dissolved in the groundwater. The thickness of the Quaternary deposits ranges from 5 to $7 \mathrm{~m}$ within the main riverbed of the Pripyat River expanding to $46 \mathrm{~m}$ in the Chernobyl Chistogalovsky ridge where subface of stratum quaternary deposits are recorded at 115-121 m of the Baltic system of elevation. The origin of the Quaternary deposits is associated with melting of the Dnieper glacier. Geomorphologically, the Quaternary deposits are currently presented by two terraces: above the floodplain terrace and the floodplain terrace.

The permeability and sorption characteristics of the Aeolic deposits and the upper part of the alluvial deposits where the floodplain deposits are localized were studied by the Institute of the Geological Sciences of the National Academy of Sciences of Ukraine and the Institute of Radiation Safety (IRSN) in France under their joint project (Dewiere 2002). According to the experimental data, the average coefficient of permeability is $4.5 \mathrm{~m} \mathrm{~d}^{-1}$ for the Eolian deposits and $0.2 \mathrm{~m} \mathrm{~d}^{-1}$ for the floodplain deposits. In the Red Forest radioactive waste interim localization facility, the layer of the floodplain deposits is anisotropic with the coefficient of horizontal permeability being equal to approximately $0.02 \mathrm{~m} \mathrm{~d}^{-1}$. The alluvial deposits below the floodplain deposits have the coefficient of permeability of $8-10 \mathrm{~m} \mathrm{~d}^{-1}$. The ${ }^{90} \mathrm{Sr}$ distribution coefficient of the Eolian deposits ranges from 0.5 to $3 \mathrm{~mL} \mathrm{~g}^{-1}$, with the average of about $2 \mathrm{~mL} \mathrm{~g}^{-1}$. The ${ }^{90} \mathrm{Sr}$ distribution coefficient of the floodplain deposits ranges from $4-10 \mathrm{~mL} \mathrm{~g}^{-1}$, with the average of 
about $7 \mathrm{~mL} \mathrm{~g}^{-1}$ (Weiss et al. 2000). The ${ }^{137} \mathrm{Cs}$ distribution coefficients in the sand deposits of the Chernobyl Exclusion Zone are much higher, ranging from $20-100 \mathrm{~mL} \mathrm{~g}^{-1}$. This fact may be related to a relatively low ${ }^{137} \mathrm{Cs}$ content in the groundwater (Olkhovik et al. 1992).

The second radiologically essential aquifer is located in the deposits of the Buchagsky and Kanevsky Eocene suites (the first confined aquifer). This aquifer is the source of the drinking water for the ChNPP facilities. The water hosting deposits are separated from the unconfined aquifer by an aquitard (poorly permeable clays and chalky clays) of the Kiev suite of the Lower Paleogene that becomes so thin that disappears completely in some places. In these locations, there is a complete hydraulic connection between the confined and unconfined aquifer. These "washaway" areas are likely to be present in the area of the ChNPP industrial site and the ChNPP Cooling Pond (Bondarkov et al. 2002). In the area affected by the Pripyat underground water intake (the main source of the drinking water at ChNPP), the chalky clay layer is only 6$10 \mathrm{~m}$ thick, thereby causing a significant cross flow from the unconfined aquifer to the confined aquifer.

Prior to the 1986 accident, radiation assessments of the groundwater were sporadic. According to the data obtained by the ChNPP Laboratory of External Health Physics, the groundwater in the vicinity of the ChNPP site (near the villages of Chistogalovka, NovoShepelichi, and Lelev), contained mostly naturally occurring radionuclides with the following concentrations measured in 1983-1985: ${ }^{226} \mathrm{Ra} 0.01-0.073 \mathrm{~Bq} \mathrm{~L}^{-1} ;{ }^{228} \mathrm{Ra} 0.021-0.048 \mathrm{~Bq} \mathrm{~L}^{-1} ;{ }^{40} \mathrm{~K}$ $0.17-1.8 \mathrm{~Bq} \mathrm{~L}^{-1}$. In some locations, the radionuclides of global origin were detected, but their concentrations were relatively low: ${ }^{137} \mathrm{Cs} 0.025 \mathrm{~Bq} \mathrm{~L}-1{ }^{-10} \mathrm{Sr} 0.0015 \mathrm{~Bq} \cdot \mathrm{L}^{-1}$.

Since the beginning of the 1986 accident mitigation activities, the protection of the underground water from radioactive contamination became one of the top priorities. In the 
summer and fall of 1986, specially designed structures were built to protect the groundwater, i.e., three vertical drainage systems: southern cutoff drainage consisting of 54 wells, shoreline cutoff drainage in the city of Pripyat consisting of 96 wells, and the drainage curtain of the ChNPP Cooling Pond consisting of 177 wells equipped with pumps and interconnected with pipes to recycle the water back into the Cooling Pond. In addition, a so called "wall in the soil" was built, which is a trench $2.8 \mathrm{~km}$ long and $30 \mathrm{~m}$ deep filled with clay materials to prevent any possible radionuclide transport from the destroyed reactor to the geological media and subsequently to the water reservoirs.

The contamination of the groundwater started much later than contamination of the surface water. The first occurrence took place on 4 October 1986 when the ${ }^{90} \mathrm{Sr}$ concentration in groundwater from monitoring well $151 / 1$ of the ChNNP Cooling Pond drainage curtain at PK133 was found to be higher than the maximum allowable ${ }^{90} \mathrm{Sr}$ concentration for drinking water $\left(14 \mathrm{~Bq} \mathrm{~L}^{-1}\right)$.

In March-April 1987, the Health Physics Division started a systematic monitoring of the groundwater. The monitoring data showed that the dynamics of the radionuclide concentrations in the groundwater were consistent with the seasonal precipitation. ${ }^{134} \mathrm{Cs},{ }^{137} \mathrm{Cs},{ }^{106} \mathrm{Ru}$, and ${ }^{90} \mathrm{Sr}$ were detected in the groundwater of the Quaternary aquifer. In September 1987, the ${ }^{134} \mathrm{Cs}$ and ${ }^{137} \mathrm{Cs}$ concentrations reached 33.3-114.7 $\mathrm{Bq} \mathrm{L}^{-1}$ in the groundwater in the monitoring wells of the shoreline cutoff drainage in the city of Pripyat and within the CHNPP industrial site. The ${ }^{90} \mathrm{Sr}$ content was recorded at $0.48 \mathrm{~Bq} \mathrm{~L}^{-1}$.

In 1988, a steady increase of the ${ }^{90} \mathrm{Sr}$ contamination of the groundwater was observed, and the maximum ${ }^{90} \mathrm{Sr}$ concentrations of $6.3-7.2 \mathrm{~Bq} \mathrm{~L}^{-1}$ were recorded in February 1988 in 
samples taken from the monitoring wells of the cutoff drainage of the ChNPP Cooling Pond drainage curtain.

In October 1989, the Health Physics Division and the All-Union Research Institute of Non-Metallic Natural Resources sampled and analyzed groundwater in one of the areas of the Red Forest, a pinewood near the ChNPP killed by the radiation and buried in-situ in trenches in 1988 , located near the operational Yanovsky drinking water intake. The ${ }^{90} \mathrm{Sr}$ concentration in the groundwater in that area was found to range from $180-1,850 \mathrm{~Bq} \mathrm{~L} \mathrm{~L}^{-1}$. The water dissolved ${ }^{239+240} \mathrm{Pu}$ was also detected with the total concentration reaching $3.7 \mathrm{~Bq} \mathrm{~L}^{-1}$ (Afonin et al. 1992). The increase of the ${ }^{90} \mathrm{Sr}$ concentration in the underground water of the Quaternary aquifer continued from 1989-1991 as shown in Table 35.

To the present time, the number of boreholes drilled by various organizations in the postChernobyl period for the groundwater monitoring needs exceeds 400 boreholes, 138 of which are included by the Continuous Monitoring Regulations (DSNVP EcoCenter 2009). The Monitoring Regulations include those wells that make monitoring of the critical points of the underground water flows more comprehensive and complete.

For the last ten years, some recommendations were implemented to upgrade the existing monitoring wells and the sampling techniques; however, the full-scale refurbishment of the groundwater monitoring system would require substantial funding. Table 36 provides results on the long-term monitoring of ${ }^{90} \mathrm{Sr}$ in groundwater at selected radioactive waste interim localization and disposal sites.

In spite of the diversity in the locations of the monitoring wells, the patterns in the groundwater contamination shown in Table 36 make it possible to identify two types of trends in the changes in the ${ }^{90} \mathrm{Sr}$ concentrations in the groundwater, specifically: 
- Type 1: a well-defined increase of the ${ }^{90} \mathrm{Sr}$ concentration in $1991-1993$ followed by a steady regular decrease (e.g., Podlesny); and

- Type 2: a delayed increase in the ${ }^{90} \mathrm{Sr}$ concentration in $1997-1998$ followed by a decrease (e.g., Stroybaza facility).

The ${ }^{137} \mathrm{Cs}$ contamination of the groundwater is significantly lower, primarily ranging from $0.01-0.4 \mathrm{kBq} \mathrm{m}^{-3}$. As shown in Table 37, several isolated increases in the ${ }^{137} \mathrm{Cs}$ concentration were recorded up to about $8 \mathrm{kBq} \mathrm{m}^{-3}$ mostly resulting from intense pumping and sluicing in the wells.

In general, the analysis of the groundwater contamination in the ChEZ makes it possible to draw the following conclusions:

- ${ }^{90} \mathrm{Sr}$ concentration in the groundwater in areas with undisturbed soils does not usually exceed $10 \mathrm{~Bq} \mathrm{~L}{ }^{-1}$;

- ${ }^{90} \mathrm{Sr}$ concentration in the groundwater in areas with disturbed soils, i.e., the areas where various decontamination and cleanup operations were performed and in the city of Pripyat, ranges from 10-20 $\mathrm{Bq} \mathrm{L}^{-1}$; and

- ${ }^{90} \mathrm{Sr}$ concentration in the areas of the radioactive waste subsurface disposal (specifically, at the Red Forest radioactive waste interim localization site and petroleum depot, ChNPP industrial site, etc.) reaches 10,000 $\mathrm{Bq} \mathrm{L}^{-1}$ and higher, i.e., these are the locations of the pronounced radioactive contamination of the groundwater.

As shown in Table $37,{ }^{137} \mathrm{Cs}$ is ubiquitous in the groundwater. However, in comparison with the ${ }^{90} \mathrm{Sr}$ concentration, the ${ }^{137} \mathrm{Cs}$ concentration is lower, generally averaging tenths and hundredths of $1 \mathrm{~Bq} \mathrm{~L} \mathrm{~L}^{-1}$. Characteristics of long-lived transuranic elements, specifically, 
plutonium isotopes and ${ }^{241} \mathrm{Am}$ that have been recently detected in groundwater samples of the "proximity zone," require further studies.

The transuranic elements were detected in the groundwater of the Red Forest radioactive waste interim localization site, as well as in the groundwater of the Peschanoe Plato radioactive waste interim localization site and in Glubokoe Lake. The concentration of the transuranic elements in the groundwater in the area of the Red Forest radioactive waste interim localization site is as follows: ${ }^{238} \mathrm{Pu} \quad 0.7-1.3 \mathrm{mBq} \cdot \mathrm{L}^{-1}$ and ${ }^{239+240} \mathrm{Pu} 1.0-3.3 \mathrm{mBq} \mathrm{L}{ }^{-1}$ (Dewiere 2002). Considering the high contamination density of the "proximity zone" by the fuel matrix particles (with their severe biological hazards), further studies of groundwater contamination by transuranic elements currently appear urgent.

\section{Status of the Artesian Well Groundwater Utilized for Drinking Water Needs}

DSNVP EcoCenter quarterly samples and analyzes water in 10 monitoring wells of the Eocene aquifer that is the source of the drinking water for the ChNPP site and the city of Chernobyl. Tables 38 and 39 provide the drinking water monitoring data and they show that the

${ }^{90} \mathrm{Sr}$ and ${ }^{137} \mathrm{Cs}$ concentrations in the drinking water do not exceed the maximum allowable concentrations listed in the Ukrainian regulatory requirements (Ministry of Health of Ukraine 1997).

\section{Groundwater Monitoring at the ChNPP Industrial Site}

The operational groundwater monitoring at the ChNPP industrial site is provided by 28 monitoring wells of S series. The S series wells were drilled after the 1986 accident and replaced 
the original wells that had not been intended for the significant radioactive contamination in the ChNPP soils. The groundwater monitoring in the ChNPP industrial site is performed by the ChNPP Radiation Safety Shop with the major goal of a timely detection of potential liquid radioactive leaks from the ChNPP operational facilities or equipment into the soils and groundwater.

The monitoring shows that the groundwater at the ChNPP industrial site has a continuous ${ }^{90} \mathrm{Sr}$ contamination with its concentration occasionally reaching $330 \mathrm{kBq} \mathrm{m}{ }^{-3}$. The ${ }^{137} \mathrm{Cs}$ contamination is less pronounced, reaching the concentrations of $40-58 \mathrm{kBq} \mathrm{m}^{-3}$. However, the ChNPP industrial site has some areas with a relatively low ${ }^{90} \mathrm{Sr}$ and ${ }^{137} \mathrm{Cs}$ contamination. The source of the ChNPP industrial site groundwater contamination is the 1986 accident. There is a fairly good correlation between the exposure dose rate at the ChNPP industrial site (resulted from the ChNPP accident related contamination of the techogenic layer located at $30 \mathrm{~cm}$ to 2-3 $\mathrm{m}$ deep) and relatively high radionuclides concentrations in the groundwater. The recorded radionuclides concentrations within the ChNPP industrial site are consistent with the groundwater contamination data in the areas of the radioactive waste subsurface disposal in the proximity zone.

In conclusion, it should be noted that the groundwater contamination is affected by a very large number of parameters, and routine monitoring does not make it possible to track the dynamics of all these parameters. The geological structure of the unconfined aquifer hosting Quaternary deposits is fairly complex and, consequently, the transport coefficients for various radionuclides will vary significantly. In addition, the underground water contamination also depends on the levels and composition of the soil contamination. For example, for the last ten years, an increase of the ${ }^{90} \mathrm{Sr}$ concentration in the groundwater has been recorded in monitoring 
wells $2 / 2$ and K-3 located in the areas with very high concentrations of ${ }^{90} \mathrm{Sr}$ fallout. The concentrations of such mobile radionuclides as ${ }^{90} \mathrm{Sr}$ also significantly depend on the annual precipitation. The groundwater radiohydrochemical mode is also significant because it affects the solubility and migration capabilities of the radionuclides. Therefore, routine monitoring has to be complemented by additional studies on characteristics of the radionuclides migration into the groundwater to be able to accurately assess and predict the dynamics of its contamination.

However, the monitoring data do make it possible to draw general conclusions on the dynamics of the ongoing processes and identify objectives for special studies. The assessments of the integral radionuclides outflows due to discharging of the underground rivers into the ChEZ surface rivers show that currently the radioactivity release is low and will remain low. The front of the groundwater with the highest contamination in the entire ChEZ is estimated to reach the Pripyat River in 2030-2035 (Shestopalov et al. 2001) with the subsequent maximum disharge ranging from $100-120 \mathrm{GBq}^{-1}$. In comparison with the expected ${ }^{90} \mathrm{Sr}$ intake with the surface water, the underground component of the total radionuclide intake will not exceed $10-15 \%$, and will not pose any essential radiation risks to the Ukrainian population outside the ChEZ.

\section{CONCLUSIONS}

The radiation monitoring data provided in this article do not claim to be complete. It is not possible in a summary to fully address the variety of all the monitoring studies conducted in the ChEZ. Therefore, some issues, such as radiobiological monitoring or radiation monitoring of so called "illegal inhabitants" (those people who without an authorization returned to their villages after the evacuation), were deliberately excluded and the article primarily focused on the 
major aspects of the monitoring conducted in the ChEZ. The authors believe that the publication of a brief history of the radiation monitoring and dynamics of the major characteristics of the radiation situation in the ChEZ will be of interest for a large range of radiation safety and radioecology specialists.

The ChEZ long-term monitoring data show that the radiation situation in the ChEZ has significantly improved due to a number of activities associated with the ChNPP accident mitigation campaign, including decontamination, collection and disposal of radioactive water, various water remediation activities, forestry and other activities, as well as due to the naturally occurring processes, such as radionuclide migration and physical decay.

Fluctuations of the dose rate in the ASKRO monitoring stations within the ChNPP industrial site depend on a number of factors, and the dominating factor is associated with the status of the ChNPP facilities, such as spent nuclear fuel, liquid and solid radioactive waste, as well as types of operations at the ChNPP and in the ChEZ. Outside the ChEZ, relatively high dose rates are characteristics of only several villages located along the northern and western 1986 fallout plumes. During the years following the ChNPP accident, the airborne contamination at the ChNPP industrial site decreased by more than three orders of magnitude. In the remote areas, the radionuclide content also decreased, but not as significantly as within the ChNPP industrial site. The radionuclide content in the air has been stable during the last ten years.

The radioactive contaminant transport outside the ChEZ with air and aqueous flows decreased. The surface contamination of the soils and flowing water reservoirs is also decreasing. Although the estimated radionuclide inventory decreases, ${ }^{90} \mathrm{Sr}$ and ${ }^{137} \mathrm{Cs}$ remain the major sources of contamination for practically all media, such as air, hydrosphere (surface and groundwater), soils, biosphere, production facilities, and construction sites. 
It should also be noted that due to the migration and redistribution processes of the ChNPP accident related radionuclides that precipitated in the ChEZ in the locations of the radioactive waste interim localization and disposal sites, in stagnant water reservoirs, in soils, in flora and fauna, practically everywhere sources of secondary radioactive contamination have been generated. In some locations, specifically, in stagnant highly radioactive water reservoirs or at the Red Forest radioactive waste surface disposal site, the newly formed secondary contamination sources become truly hazardous for the personnel and potentially hazardous for the population inhabiting the areas adjacent to the ChEZ.

As previously discussed, one of the urgent problems remains the problem of contamination of the Dnieper River basin, with the Pripyat River being a tributary of the Dnieper River. Approximately $60-70 \%$ of the ${ }^{90} \mathrm{Sr}$ and about $10 \%$ of the ${ }^{137} \mathrm{Cs}$ have been transferred outside the $\mathrm{ChEZ}$, with the surface water being the major route for the radionuclide transport.

Complex multi-factor processes of radionuclide redistribution in the soils are in progress in the ChEZ, and these processes are the key processes affecting the groundwater contamination. The contamination increase in the Quaternary aquifer in the area of locations of the major radioactive sites may present a hazard for a normal operation of the drinking water intake facilities that provide drinking water for the ChNPP industrial site and other organizations within the ChEZ. The radioactive waste interim localization sites remain significant sources of groundwater contamination. Actually, due to the current groundwater contamination, a new hydrogeological media that has not existed earlier under the natural conditions is emerging.

The regulatory issues for the groundwater contamination remain open because the existing Ukrainian and (World) regulations only apply to the groundwater used for drinking water. If this water is not used for drinking, no maximum allowable contamination limits 
associated with technogenic causes are enforced. The contamination of the sub-riverbed aqueous flow of the Pripyat River that is not currently monitored can also cause some unpredictable consequences and potential contamination of the Dnieper basin.

In some areas of the ChEZ, e.g., in the right bank floodplain of the Pripyat River, so called "distributed" sources of migration that are located in the natural terrain started playing a large role in the ${ }^{90} \mathrm{Sr}$ transfer with the groundwater. The radionuclide inventory consolidated in the upper soil layers in such areas is consistent with the amount of the localized radioactive waste in the adjacent areas.

The distribution of radionuclides in the soil profile depends on the density of the original 1986 fallout, geochemical and climatic conditions, lithofacies composition of the soil, and the distance to the groundwater. Currently, approximately $70-90 \%$ of the radionuclide inventory is present in the $0-10 \mathrm{~cm}$ deep layer. The contamination of the upper $0-5 \mathrm{~cm}$ deep layer goes down due to the radionuclides physical decay and migration decreases and currently the upper $0-5 \mathrm{~cm}$ deep layer contains $30-50 \%$ of the ${ }^{90} \mathrm{Sr}$ inventory and $50-70 \%$ of the ${ }^{137} \mathrm{Cs}$ inventory. Transport of transuranic elements, the least mobile radionuclides, to deeper soil layers has also been recorded. Practically all radionuclides are currently detected as deep as $50 \mathrm{~cm}$ below the ground level.

The fuel particles that affect contamination of the "proximity" zone, as well as the western and southern plume routes undergo the process of destruction. According to some estimates, ${ }^{90} \mathrm{Sr}$ has completely leached from the fuel particles in practically the entire ChEZ. Transport of transuranic elements earlier consolidated in the fuel particles to the environment is expected. 
The radiation monitoring system in the ChEZ that was developed after the ChNPP accident continues to perform its mission. The monitoring has to be continued and its organization has to be continuously adjusted and improved to address changes in the radiation situation. The groundwater monitoring will have to be upgraded, and the radiobiological monitoring system will have to be developed.

The overall objective of the ChEZ is to remediate its contaminated areas and revise the ChEZ status based on the actual radioecological parameters that may make it possible to gradually return the population to the non-contaminated areas. The return of the population will require a well-organized radiation monitoring program.

The draft New Concept of the ChEZ development addresses the zoning strategy in the ChEZ based on the intended activities. An industrial zone will be identified including the ChNPP, as well as the radioactive waste processing and storage facilities. A possibility of constructing a geological repository for high level and long-lived radioactive waste at the ChEZ is being considered, and it will require development of a special engineering and technical infrastructure. The industrial zone will be separated from the remaining territory by a buffer zone where any industrial activities will be strictly limited. Finally, a significant part of the ChEZ territory will be converted into a reserve where no industrial activities will be permitted to preserve the natural terrains and the biological diversity of the region. The reserve will make it possible to study the radioecological factors controlled by natural conditions only. One of the phases of this development was the creation of the Chernobylskaya Putscha wildlife refuge in 2007.

Regardless of the ChEZ zoning structure, the radioecological monitoring in the ChEZ has to continue to optimize the management strategy for the contaminated sites, develop fundamental 
and practical knowledge on the dynamics and evolution of the radionuclides, and assist in the decision making process associated with additional engineering barriers and implementation of environmental remediation technologies.

For the 25 years following the ChNPP 1986 accident, a large amount of monitoring data has been accumulated on the changes of the radiation situation in the ChEZ, but this information has not been used to the full extent so far. The task of collecting, updating, assessing and verifying this information still remains valid, so that it can become available for the international community of radioecologists.

Acknowledgments - The authors would like to thank Ines Triay, Yvette Collazo, Kurt Gerdes, and Ana Han for their support of the U.S. Department of Energy Office of Environmental Management's International Cooperative Program with IRL. The authors would like to express their appreciation to the Chernobyl Exclusion Zone Administration for their support of this article. The authors would also like to express their gratitude to Tatyana Albert (Thomas E. Albert and Associates, Inc.) for translating documents and reports prepared at SRNL and IRL, and Jennifer Grant, Yasmine Elraheb, and Miranda LaBone for their help with the tables and figures.

Disclaimer - This manuscript has been co-authored by Savannah River Nuclear Solutions, LLC under Contract No. DE-AC09-08SR22470 with the U.S. Department of Energy. The United States Government retains and the publisher, by accepting this article for publication, acknowledges that the United States Government retains a non-exclusive, paid-up, irrevocable, worldwide license to publish or reproduce the published form of this work, or allow others to do 
so, for United States Government purposes. Mention of trade names or commercial products does not constitute endorsement or recommendation for use by the authors or their corresponding organizations.

\section{REFERENCES}

Abagyan AA, Asmolov VG, Gus'kova AK, Demin VF, Il'in LA, Izrael YA, Kalugin AK, Konviz VS, Kuz'min II, Kuntsevich AD, Legasov VA, Malkin SD, Mysenkov AI, Pavlovsky OA, Petrov VN, Pikalov VK, Protsenko AN, Ryazantsev EP, Sivintsev YuV, Sukhoruchkin VK, Tokarenko VF, Khrulev AA, Shakh OA. Accident at the Chernobyl NPP and its consequences. Information Prepared for IAEA Experts Meeting (25-29 August, 1986, Vienna). Atomnaya Energiya, Vol. 61, Issue 5; 1986.

Afonin SV, Vasilchenko DL, Ivano YP, Sukhoruchkin AK. Problems of radiation monitoring of aqueous objects in the $30 \mathrm{~km}$ zone around the ChNPP. Collection of articles:Chernobyl92. Proceedings of the $3^{\text {rd }}$ All-Union Scientific and Technical Meeting on the Results of the Activities on the Mitigation of the ChNPP Accident; Zeleny Mys; Vol. 1, Part 1; 1992.

Aleksakhin RM, Buldakov LA, Gubanov VA, Drozhko EH, Ilyin LA, Kryshev II, Linge II, Romanov GN, Savkin MN, Saurov MN, Tikhomirov FA, Kholina YuB. Major Radiation Accidents: Consequences and Protective Measures. Ilyin LA and Gubanov VA, eds: Moscow; IzdAT, 752; 2001.

Bondarkov MD, Bugaj DA, Jepo SP, Matoshko AV, Maksimenko AM, Oskolkov BYa, Skalsky AS. Comprehensive assessment of the radiation environmental safety of operation of ChNPP sites in the industrial area and the city of Slavutich. Chernobyl Center on Nuclear and Radiation Safety, Radioactive Waste, and Radioecology. Slavutich, Ukraine: 2002 R\&D Report. State Registration Number: 0102U006098; 2002.

Borovoy AA, Begichev SN, Burlakov EV, Gavrilov SL, Dovbeyko AA, Levina LA, Markushev VM, Marchenko AE, Stroganov AA, Tataurov AL. Fuel of the ChNPP reactor unit \# 4 (brief reference book). Preprint. Moscow: Kurchatov Atomic Energy Institute, IAE5268/3; 1990.

Borovoy AA, Gagarinsky AY. Radionuclide release from the destroyed ChNPP reactor. Atomnaya Energoya 90:137 - 145; Moscow; 2001.

Bulgakov AA, Konoplev AV, Kanivets VV, Voytsekhovich OV. Modeling the long-term dynamics of radionuclides in rivers. Proc. International congress on the radioecology/ecotoxicology of contaminated and estuarine environments. Aix en Provance; 2001.

Dewiere L. Validating a pilot plan in the Chernobyl exclusion area by means of experiments. Institut de Radioprotection et de surete nucleaire. (IRSN). Fontenay-Aux-Rose, France. Appendix VI-b; 2002. 
DSNVP ECOCENTER. Radiation Status of the Exclusion Zone. Issues of.1995-2010 bulletins on the environmental status of the exclusion and involuntary (mandatory) resettlement zone. Ministry of the Emergency Situations of Ukraine. Chernobylatominform, Chernobyl; 1995-2010

DSNVP ECOCENTER. Regulated activities of the DSNVP ecocenter on radiation environmental monitoring and health physics monitoring in the exclusion and involuntary (mandatory) resettlement zone. Chernobylatominform, Chernobyl; 2009.

Egorov YA, Kazakov SV, Leonov SV, Staurin NV. Radiation status of the ChNPP cooling pond in May of 1986. Chernobylatominform; Chernobyl; 1988.

Gaschak SP, Zalessky OO, Buntova OG, Vishnevsky DO, Kotlyarov OM. Fauna of vertebrate animals in the Chernobyl zone of Ukraine. Chernobyl Center on Nuclear and Radiation Safety, Radioactive Waste, and Radioecology; Slavutich; 2006a.

Gaschak SP, Vishnevsky DA, Zalessky OA. Fauna of vertebrate animals of the Chernobyl zone as a precursor for establishing reserves in the Chernobyl zone. Bulletin on the Environmental Status of the Exclusion and Involuntary (Mandatory) Rsettlement Zone Issue 27: Chernobylatominform, Chernobyl: 2006b.

Gavrikov OK, Guldin AN, Komarov VI, Malkov VL, Smirnov NV, Sukhoruchkini AK, Prosukuryakov AG. Major objectives of the external health physics in the emergency zone. In: Chernobyl-88. Proceedings of the $1^{\text {st }}$ All-Union Scientific and Technical Meeting on the Results of the Activities on the Mitigation of the ChNPP Accident. Ignatenko EI, ed.: Chernobyl; 1989.

Gavriluk VI, Zheltonozhsky VA, Kazakov SV, Lashko TN, Muzalev PN, Stukin ED, Sukhoruchkin AK, Shustov AV, Scherbachenko AM. Changes in the contamination levels in the $30 \mathrm{~km}$ Chernobyl zone. In: Chernobyl-90. Proceedings of $2^{\text {nd }}$ All-Union Scientific and Technical Meeting on the Results of the Activities on the Mitigation of the ChNPP Accident. Senin E.v, ed.: 46-53, Vol. 1; 1990.

Godun BO, Bondarenko OO, Kireev SI, Vishnevsky DO. Upgrades to the automated system of the radiation monitoring of the Chernobyl exclusion zone. Bulletin on the Environmental Status of the Exclusion and Involuntary (Mandatory) Resettlement Zone, 1 (33): 41-51; 2009.

Ignatenko EI, Komarov VI, Zverkov VA, Proskuryakov AG. Radiation situation in the $30 \mathrm{~km}$ ChNPP zone. In: Chernobyl-88. Proceedings of the $1^{\text {st }}$ All-Union Scientific and Technical Meeting on the Results of the Activities on the Mitigation of the ChNPP Accident. Ignatenko EI, ed.: Vol.1, Chernobyl; 1989.

International Atomic Energy Agency (IAEA). Environmental and source monitoring for purposes of radiation protection. Safety Standards Series. Vienna; IAEA-RS-G-1.8; 2005.

International Atomic Energy Agency (IAEA). Programs and systems for source and environmental radiation monitoring, Safety Reports Series. Vienna; ISSN 1020-6450; 2010.

International Atomic Energy Agency (IAEA Workshop). State radioactive waste storage facility creation strategy in geological formations. 8-10 November 2006 Workshop. Kiev; 2006. 
International Commission on Radiological Protection. (ICRP). Principles of monitoring for the radiation protection of the population. Oxford: Pergamon Press; ICRP Publication 43. Ann ICRP 15; 1985.

Industrial Standard. Protection of the environment; atmosphere: general requirements for sampling radioactive aeorosols in the ground level air. Moscow, OST- 95 10123-85; 1985.

Ivanov YP. Statement of the health physics division; spectrometric and radiochemical analysis data for the environmental objects in October-December 1993; 1994.

Izrael YuA,Vakulovsky SM, Vetrov VA, Petrov VN, Rovinsky FY, Stukin ED. Chernobyl: radiaoctive contamination of the environmental media. Leningrad: Gidrometeoizdat, 296; 1990.

Kashparov VA. Formation and dynamics of the radioactive contamination of the environment following the ChNPP accident. Collection of Scientific Articles. Kiev: Naukova Dumka; $2001 \mathrm{a}$.

Kashparov VA, Lundin SM, Kadygrib AM, Protsak VP, Levchuk SE, Yoschenko VI, Kashpur VA, Talerko NN. Radiological and Hygienic Assessment of Consequences of Wild Fires in the Territory Contaminated as a Result of the Cherhobyl Accident. Hygiene and Sanitation, Vol. 1, pp. 30 - 35; 2001b (In Russian).

Kazakov SV. Management of the radiation status of ChNPP cooling ponds. Kiev: Tekhnika; 1995.

Kireev CI, Godun BO, Obrizan SM, Khalyava VG, Bitsulya VV, Vishnevsky DO, Kupchenko PG, Nazarov OB, Petrov MF, Pipipchuk TV, Dzhigar OO. Report on the radiation status in the Chernobyl exclusion zone in 2006, DSNVP Ecocenter. Chernobyl; 2007.

Kireev CI, Bespaly MV, Evsienko MG, Kedranovsky MV, Godun BO, Omelyanenko OI, Doroshenko OA, Mazay SM, Vlasenko GM, Tepikin VE, Zholobov AG, Pazenko OV, Motuz MO, Mischenko OG. Report on the DSNVP Ecocenter Activities in 2009. Chernobyl; 2010.

Korotkov VT, Trusov EA, Garin EV, Frantsuzov AK. Report on the status of radiation and environmental safety in 1991. Slavutich; 1992.

Marey AN, Zykova AS. Methodological recommendations on the sanitary monitoring of the radioactive content in environmental objects. Approved by Burgasov PN, Sanitary Surgeon General of the USSR, 3 December 1979. Marey AN, Zykova AS, eds: 336 p; Moscow, USSR; 1980.

Ministry of Health of Ukraine. Norms of radiation safety of Ukraine. Kiev, Ukraine; 1997.

Olkhovik YuA, Koromyslichenko TI, Gorgotskaya LI. Evaluation of sorption capabilities of the soils in the ChNPP "proximity" zone. Academy of Science of Ukraine \#7; 1992.

Oskolkov BY, Drapeko GF, Korotkov VT, Nosovsky AV, Maksimenko AM, Borozan AM. Radiation ecological passport of the state special enterprise Chernobylskaya AES. Slavutich, Ukraine; 1996.

Pashevich VI, Kononovich AL. Impact of the ChNPP cooling pond on the aqueous system of the region. VNIIAS, ChNPP, R\&D Report; 1986. 
Pazukhin EM. Lava-like fuel containing masses of the ChNPP reactor unit \# 4; physical and chemical properties; scenario of formation; environmental impact. Post-Doctorate Thesis, Specialty \# 21.06.01. Chernobyl, manuscript; 1999.

Petrov MF. Rare and endangered species of plants in the ChNPP exclusion zone. Bulletin on the Environmental Status of the Exclusion and Involuntary (Mandatory) Resettlement Zone Issue \# 28, Chernobylinform; Chernobyl; 2006.

Samoylenko YN, Starodumov VM, Karpan NV. Organization of the radiation monitoring. In: Chernobyl-88. Proceedings of the $1^{\text {st }}$ All-Union Scientific and Technical Meeting on the Results of the Activities on the Mitigation of the ChNPP Accident. Ignatenko EI, ed: Chernobyl; 1989.

Senin EV. Major results and areas of the research activities in the $30 \mathrm{~km} \mathrm{ChNPP}$ zone during the recent past and in the short term future. In: Chernobyl-92. Proceedings of the $3^{\text {rd }}$ AllUnion Scientific and Technical Meeting. Zeleny Mys 1; 1992.

Shestopalov VM, Lyal'ko VI, Sitnikov AB, Rudenko YuF, Jepo SP, Skalsky AS, Bugay DA, Bublyas' VN, Bondarenko GN, Kononenko LV, Onischenko IP, Shevchenko AL, Gudzenko VV, Nasedkin IYu, Kukharenko DE, Panasuk NI. Water exchange in the hydrogeological structures and the Chernobyl catastrophe, 2 volumes. Shestopalov VM, ed: National Academy of Sciences of Ukraine, Kiev: Institute of the Geological Sciences of the National Academy of Sciences of Ukrain, Vol. 1; 2001.

SP AES-79. Sanitary rules for design and operation of nuclear power plants. Moscow; 1979.

Teplov PV, Shaposhnikov BG, Groshev IM, Fedulov VF, Lebedeva OE, Maslov YuA, Shtverlov VV, Kazakov SV, Smirnov NV, Krestyaninov VA, Demchenko SM. Studies of radiation situation at the ChNPP after the accident . In: CHERNOBYL-88. Proceedings of the $1^{\text {st }}$ All-Union Scientific and Technical Meeting on the Results of the Activities on the Mitigation of the ChNPP Accident. Ignatenko EI, ed: Chernobyl; 1989.

Vasilchenko DL, Kazakov SV, Malkov VL, Senin EV, Sukhoruchkin AK, Chekalov AG. Radiation status of the environment in the ChNPP area after the 1986 accident. In: Chernobyl-90. Proceedings of the $2^{\text {nd }}$ All-Union Scientific and Technical Meeting on the Results of the Activities on the Mitigation of the ChNPP Accident. Senin EV, ed: Vol. 1, 97-103; Chernobyl; 1990.

Vishnevsky VI. Rivers and water reservoirs of Ukraine, status and use. 279, Kiev; 2001.

Voytsekhovitch OV, Zheleznyak MI, Margelashvili NY, Laptev GV, Perepelyatnikov GP, Klenus VG, Belyaev VV, Nasvit OI, Ryabov IN, Belova NP, Haddering P, Van Aerssen A, Berkovsky VB, Los' IP, Bugay DA, Jepo SP, Skalsky AS. Radioecology of aqueous obejcts in the area affected by the ChNPP accident. Monitoring of Radioactive Contamination of the Natural Water Reservoirs of Ukraine Vol.1; Chernobylinform; Kiev; 1997.

Weiss D, Larue PJ, Bogorinski P, Watermeyer V, Voytsekhovitch OV, Sobotovich E, Bugay DA, Oskolkov BY. Collection and analysis of information and data related to the contamination of the Chernobyl cooling pond. Final report on CEC-Contract No.: B7$5350 ; 2000$. 


\section{FIGURE CAPTIONS}

Fig. 1. Relative daily release of radionuclides from the destroyed reactor \#4 into the atmosphere (without inert radioactive gases), (\% of total) (Abagyan et al. 1986).

Fig. 2. Exposure dose rates as of 10 May 1986 according to the USSR Goskomgidromet data (original units of $\mathrm{mrem} \mathrm{h}^{-1}$ ).

Fig. 3. Schematic of the Chernobyl exclusion zone showing locations of the automated radiation monitoring system (ASKRS stations) in 2009.

Fig. 4. Equivalent dose rate changes in 1993-2008, (logarithmic scale, $\mu \mathrm{Sv} \mathrm{h}^{-1}$ ). A) $\mathrm{ChNPP}$ industrial site. B) 10-km supervised area.

Fig. 5. Average monthly equivalent dose rate values at the ASKRS stations in $2009,\left(n S v h^{-1}\right)$. A) ChNPP industrial site. B) $10-\mathrm{km}$ supervised area.

Fig. 6. Impact of the snow coverage on the exposure dose rate (EDR); Chistogalovka ASKRO station in 2007.

Fig. 7. ${ }^{90}$ Sr contamination map of the ChEZ according to the 1997 data (Kashparov 2001).

Fig. 8. Locations of the soil study sites of the DSNVP EcoCenter.

Fig. 9. ${ }^{137}$ Cs percent distribution in the soil profiles at the soil study sites during 1999-2009. A) LP-2 (watershed plain). B) LP-11 watershed plain. C) LP-12 (watershed plain).

D) LP-7 (above the floodplain terrace). E) LP-6 (the Pripyat River floodplain). F) LP-13 (left bank floodplain).

Fig. 10. ${ }^{90}$ Sr percent distribution in the soil profiles at the soil study sites during 1999-2009. A) LP-1 (watershed plain) B) LP-3 (watershed plain) C) LP-12 (above the floodplain terrace) D) LP-5 (above the floodplain terrace) E) LP-10 (above the floodplain terrace)

F) LP-13 (Left Bank, above the floodplain terrace) G) LP-6 (Pripyat River floodplain) H) LP-9 (Pripyat River floodplain).

Fig.11. Changes in ${ }^{90} \mathrm{Sr}$ total activity in the $20 \mathrm{~cm}$ deep soil layer during 1999-2009. A) Watershed plain. B) Above the floodplain terrace. C) Floodplain.

Fig. 12. Changes in the A) $\left.{ }^{238} \mathrm{Pu}, \mathrm{B}\right){ }^{239+240} \mathrm{Pu}$, and C) ${ }^{241} \mathrm{Am}$ total activity in the $10 \mathrm{~cm}$ deep soil layer at representative soil study sites during 1999-2009: (straight lines show the trend lines).

Fig. 13. Distribution of transuranic radionuclides in the soil profile, (\% of total). A) ${ }^{238} \mathrm{Pu} \mathrm{LP}-3$ (watershed plain). B) ${ }^{238} \mathrm{Pu}$ LP-5 (above the floodplain terrace). C) ${ }^{238} \mathrm{Pu}$ LP-9 (floodplain). D) ${ }^{239+240} \mathrm{Pu}$ LP-3 (watershed plain). E) $239+240 \mathrm{Pu}$ LP-5 (above the floodplain terrace) F) ${ }^{239+240} \mathrm{Pu}$ LP-9 (floodplain). G) 241 Am LP-3 (watershed plain) H) ${ }^{241}$ Am LP-5 (above the floodplain terrace). I) ${ }^{241}$ Am LP-9 (floodplain).

Fig. 14. Airborne ${ }^{137} \mathrm{Cs}$ concentration changes in 1987-2009. A) ChNNP industrial site. B) ChEZ.

Fig. 15. Changes in the ${ }^{137} \mathrm{Cs}$ and ${ }^{90} \mathrm{Sr}$ content in the Pripyat river (the city of Chernobyl station) and annual water flow rates (Kireev et al. 2010). 


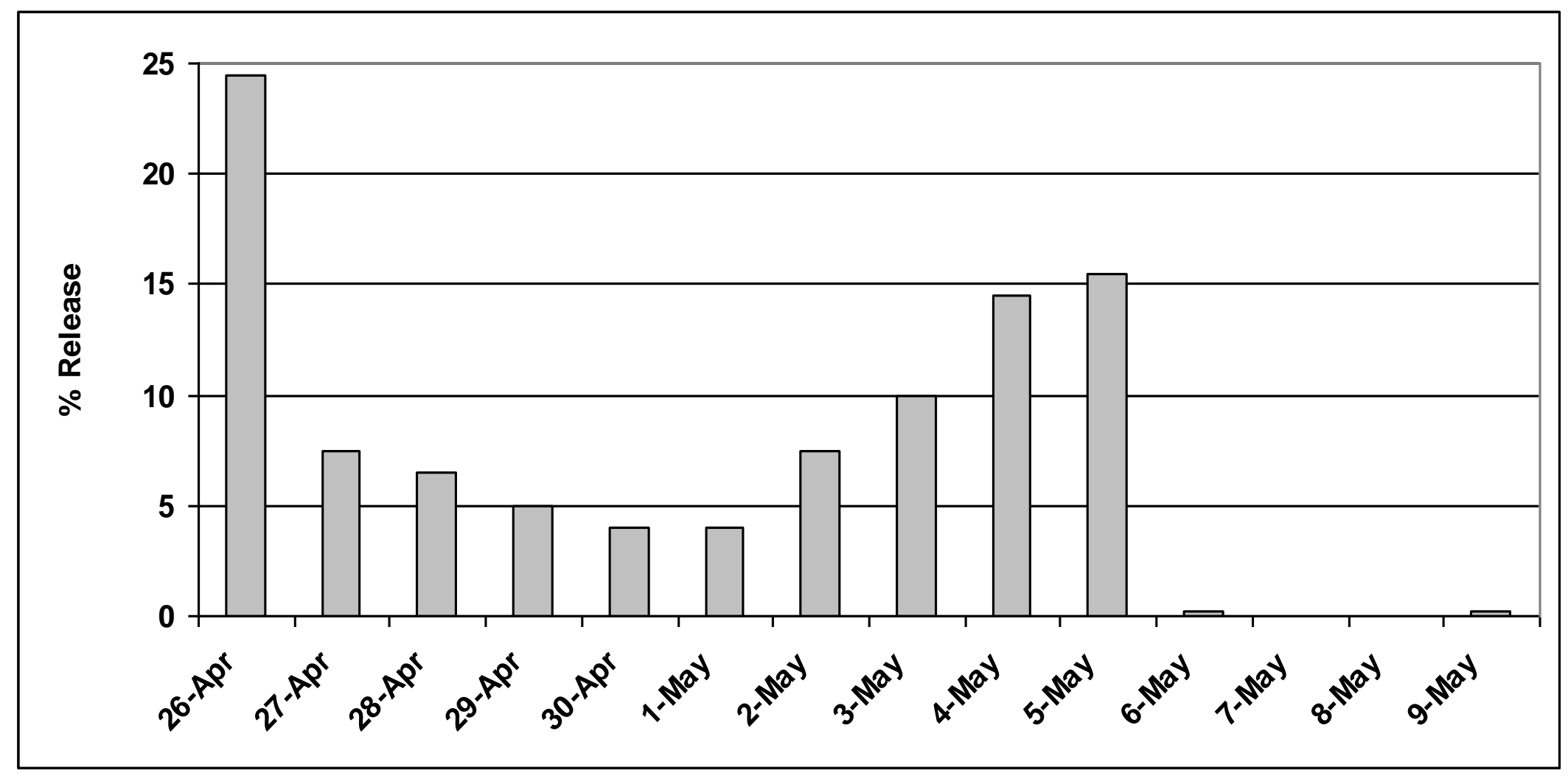




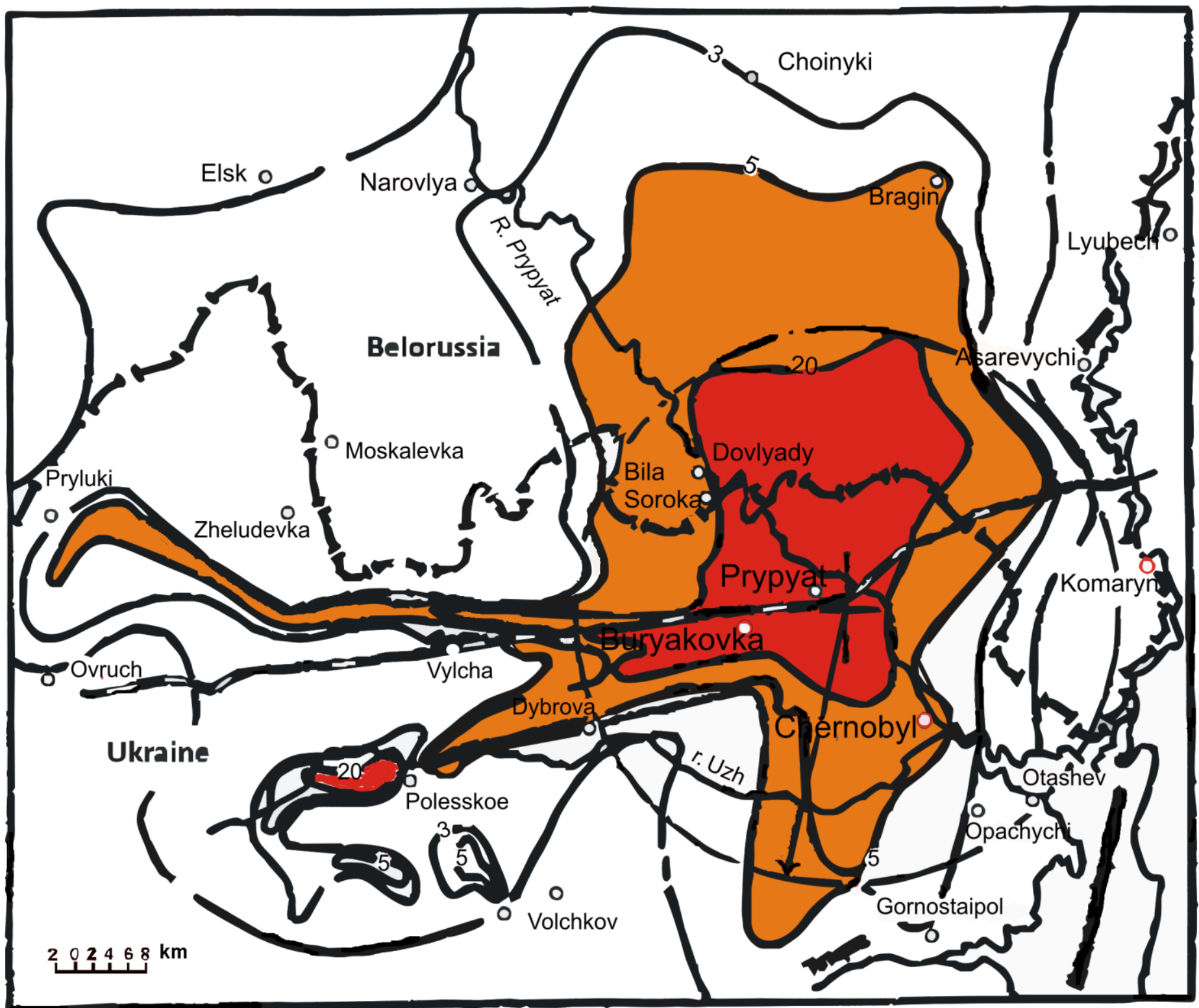




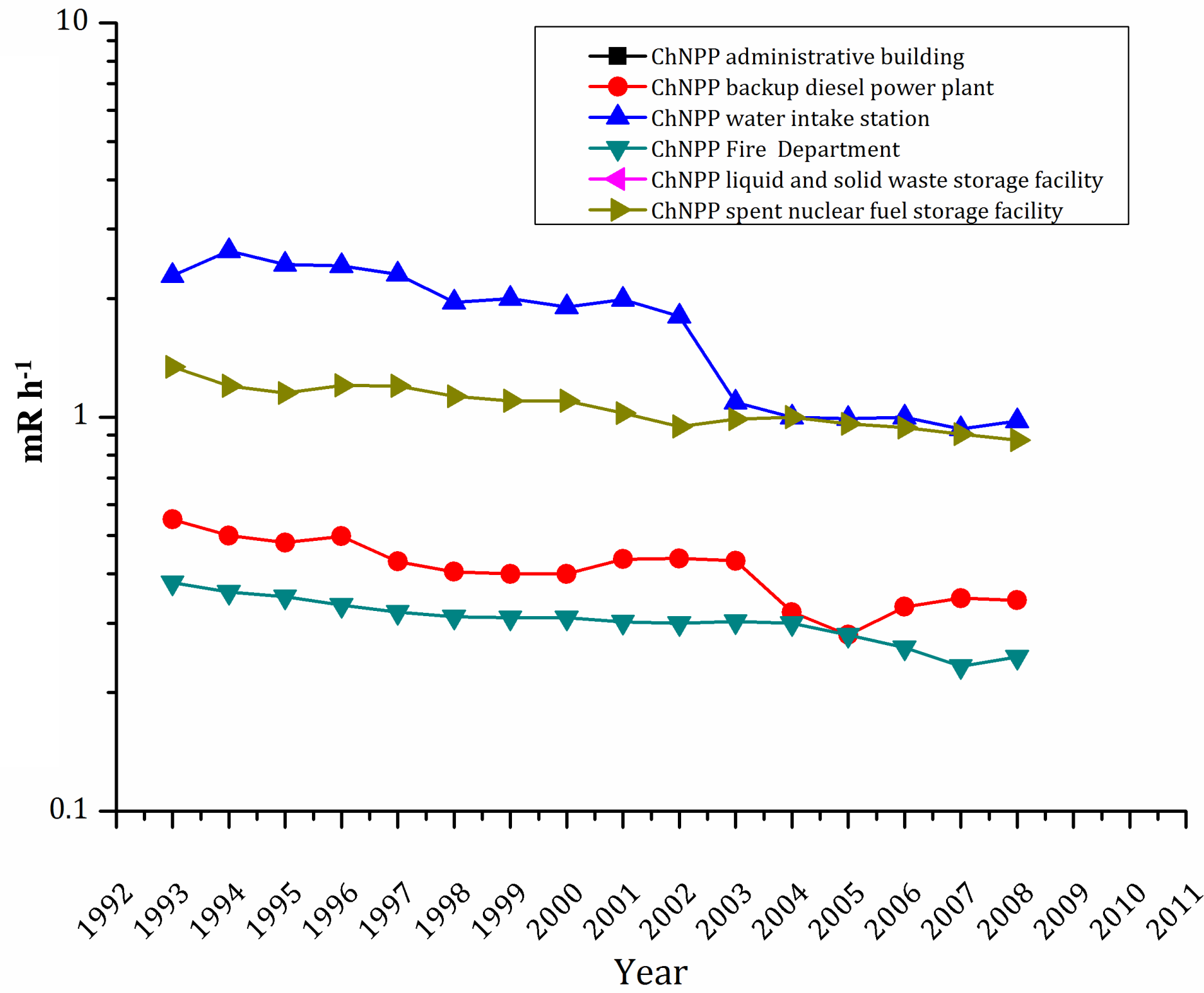

A 


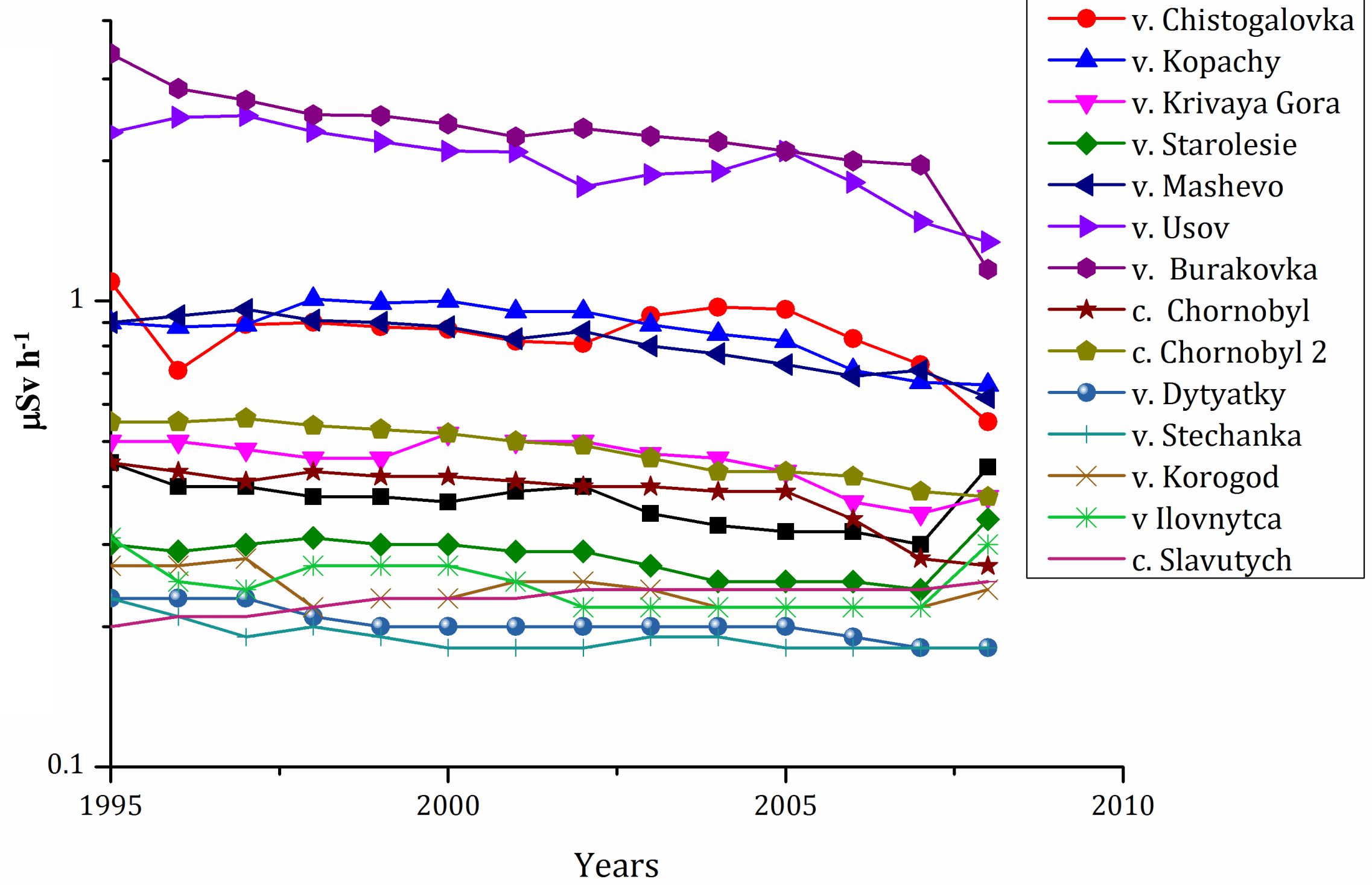

B 


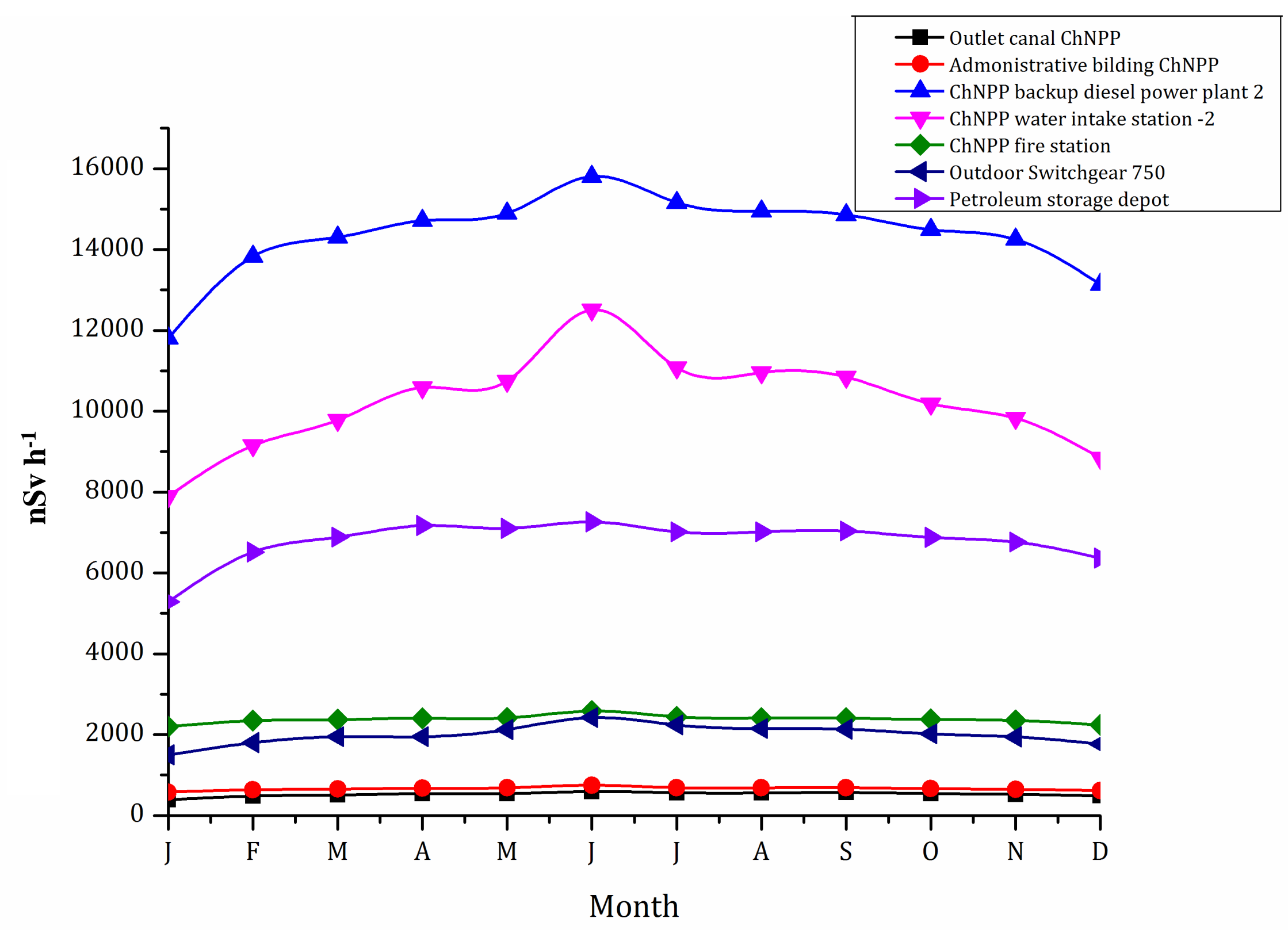

A 


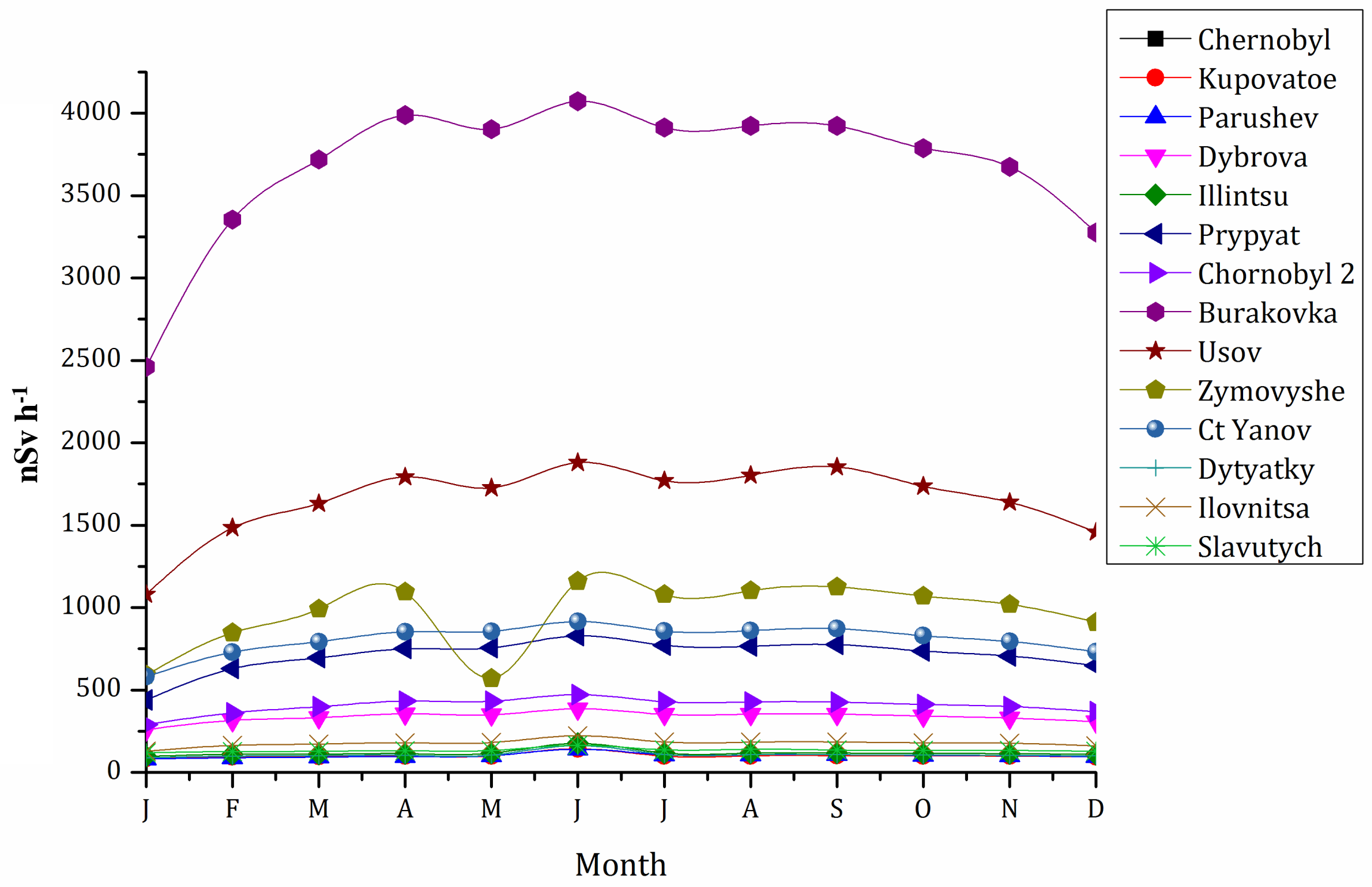

B 


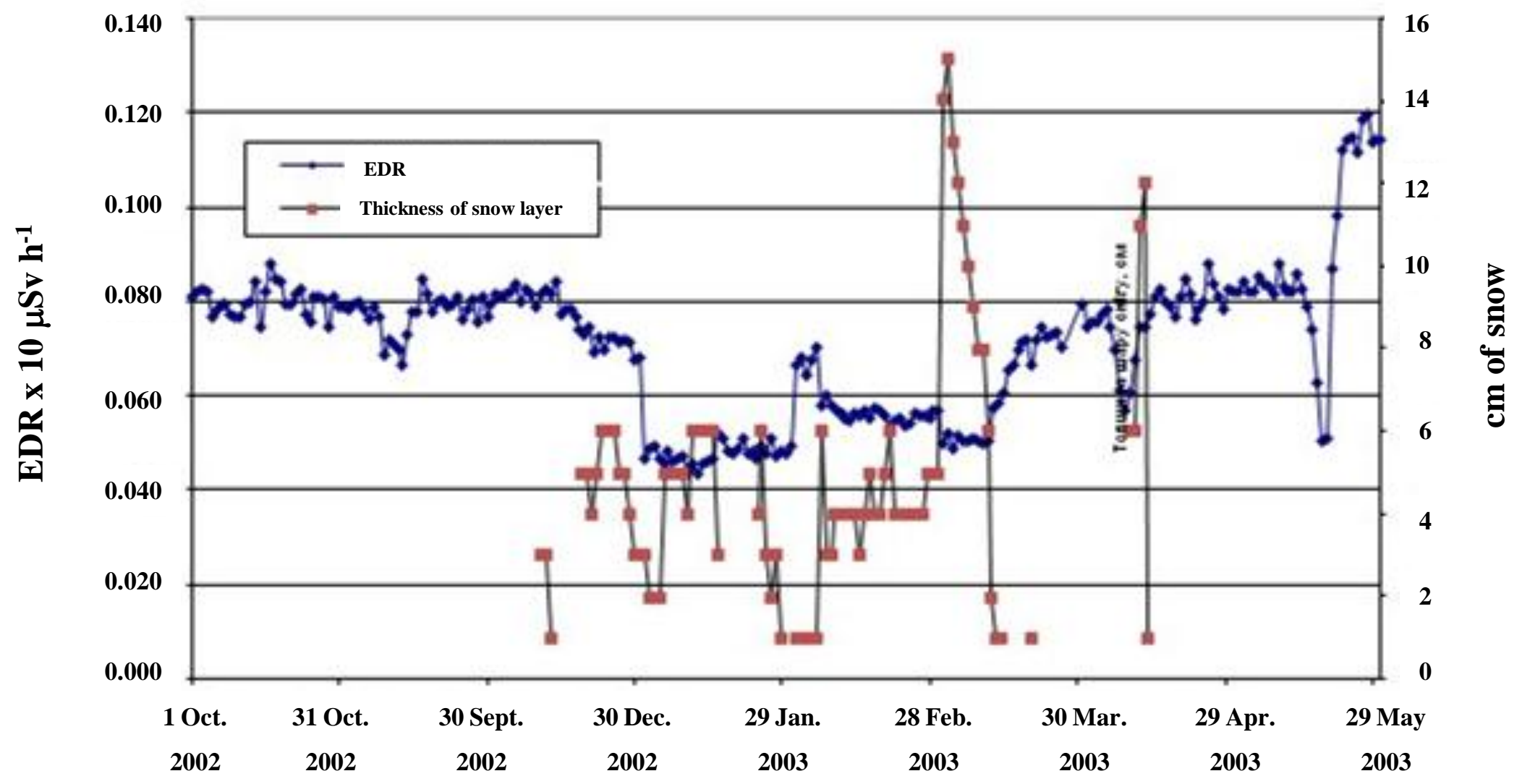




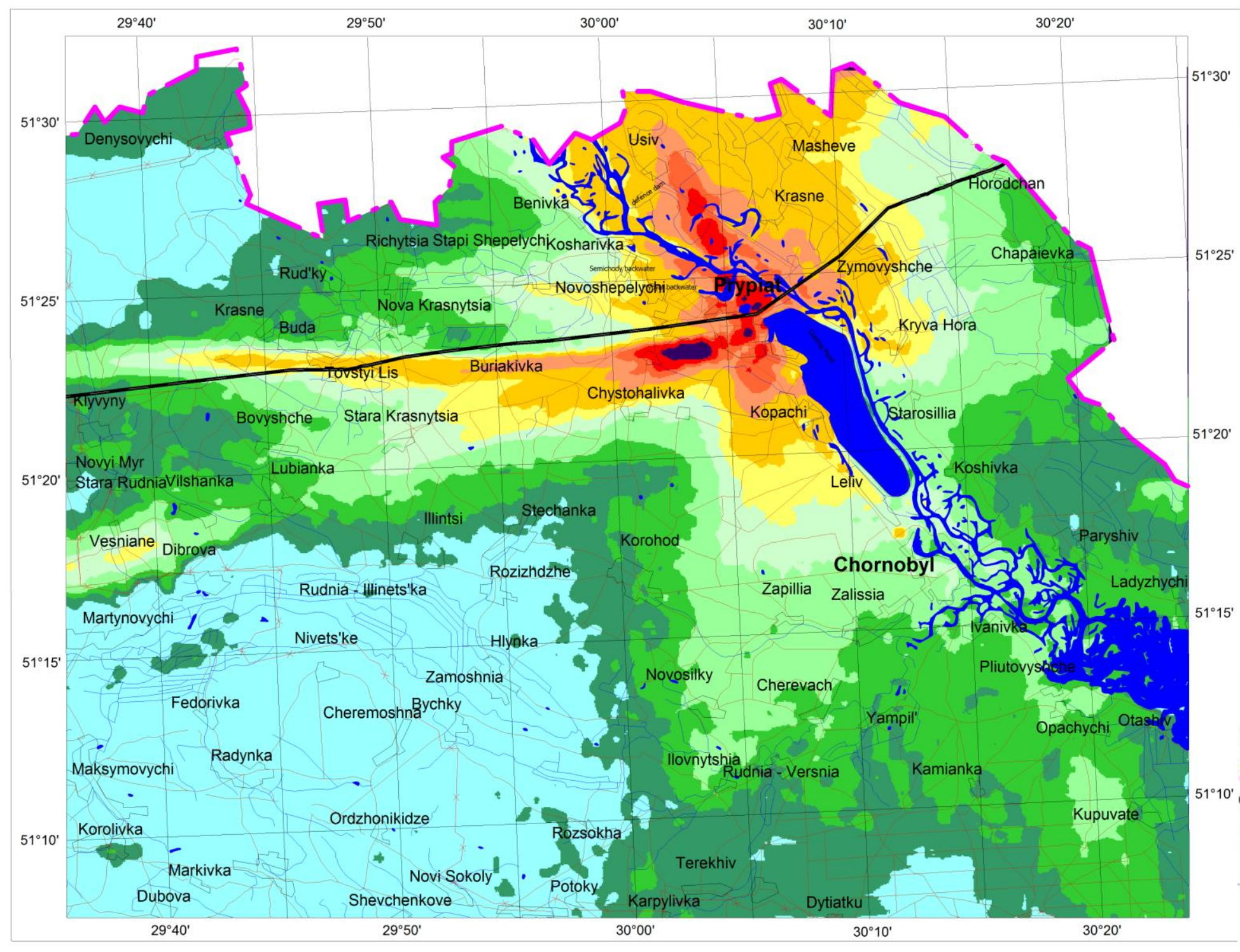

$\mathbf{k B q} \mathbf{h}^{-1}$
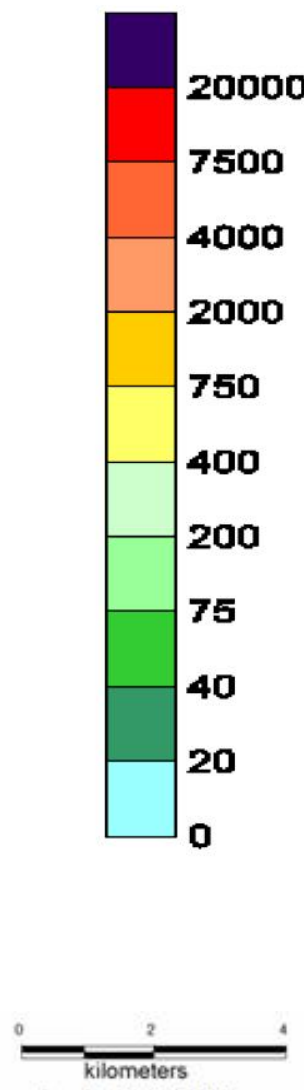

scale 1:200000

- state border

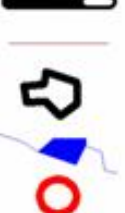

- railway

- roads

- towns and villages

- rivers and lakes

- exclusion zone border 


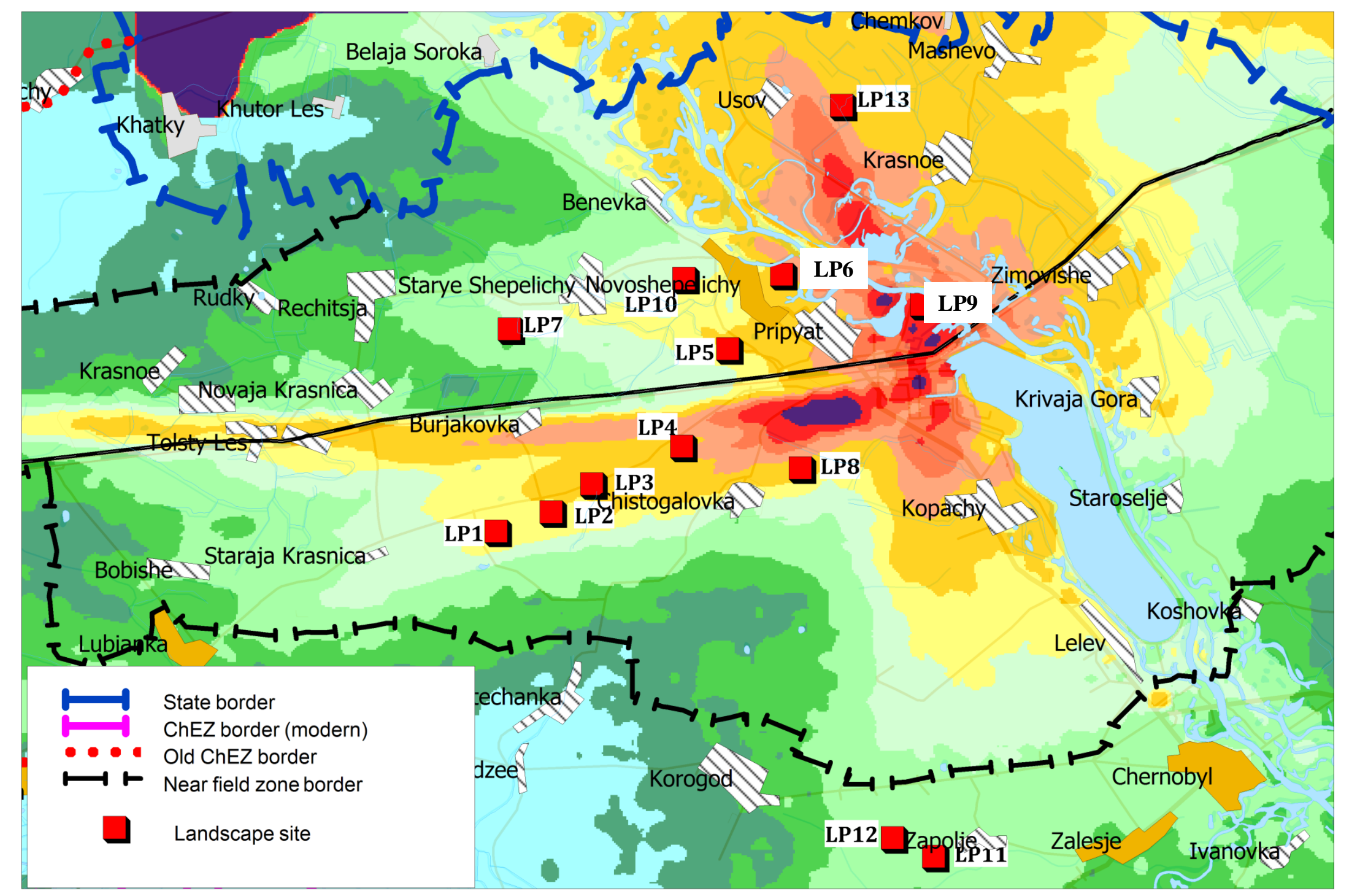


Figure 9

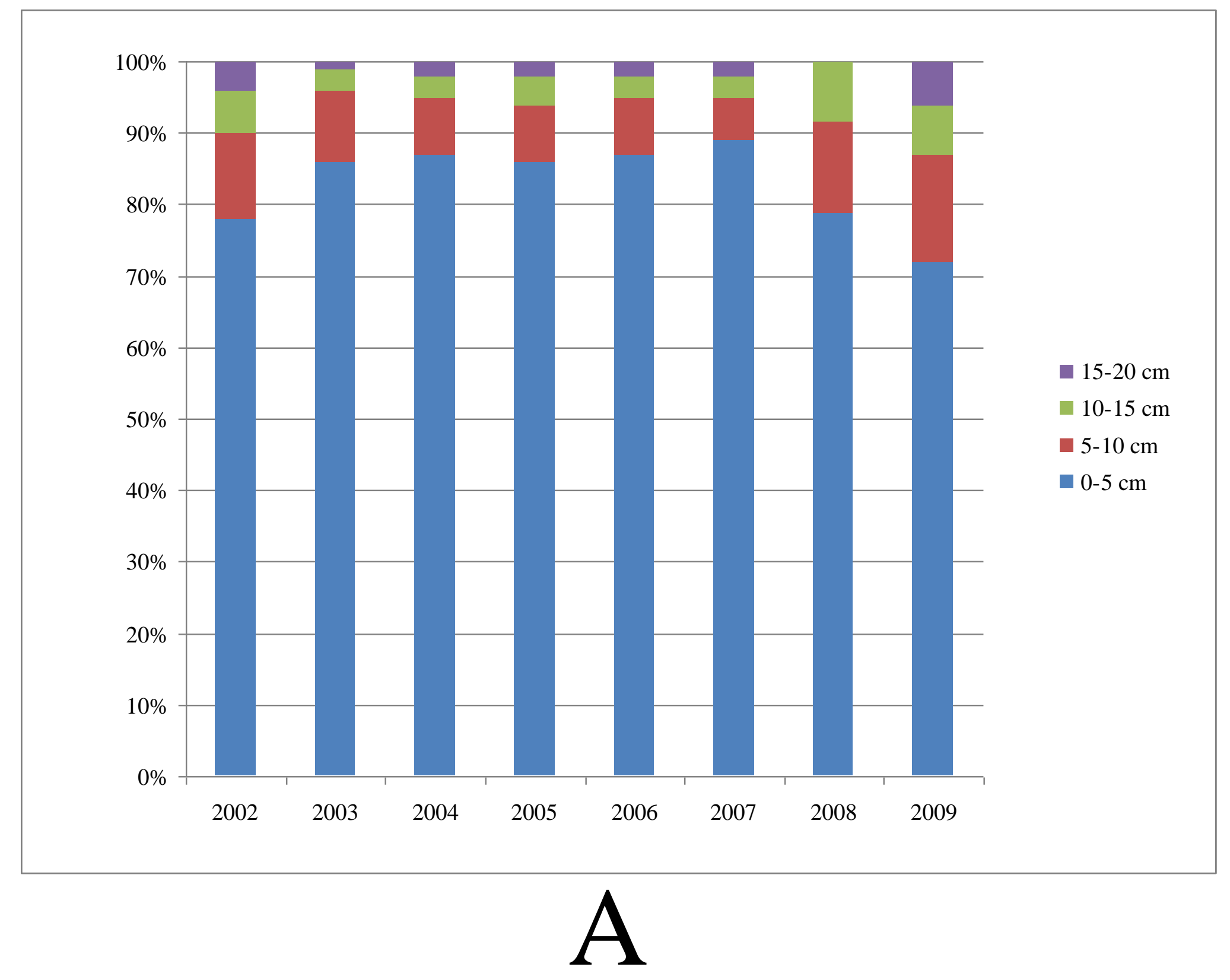



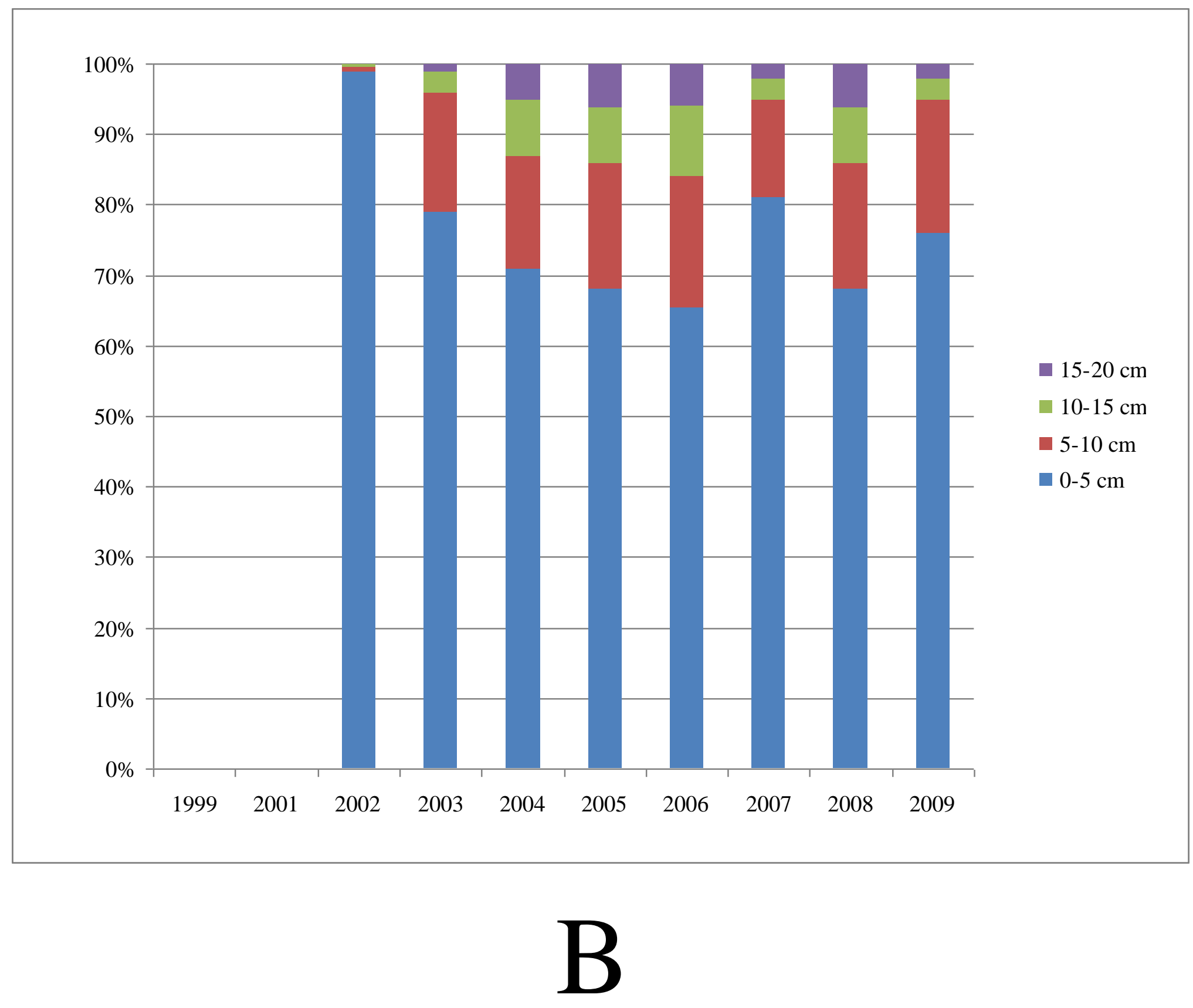

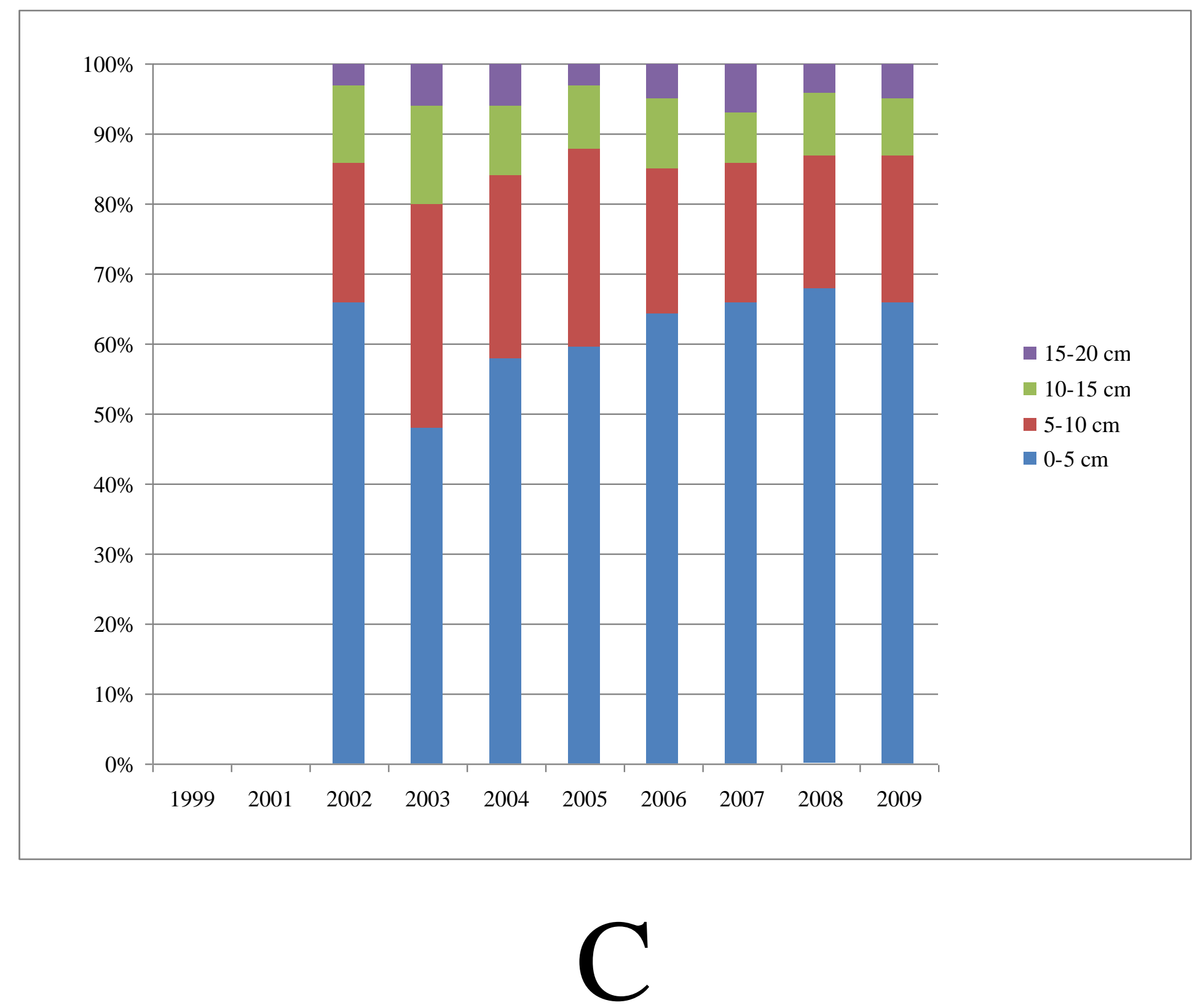

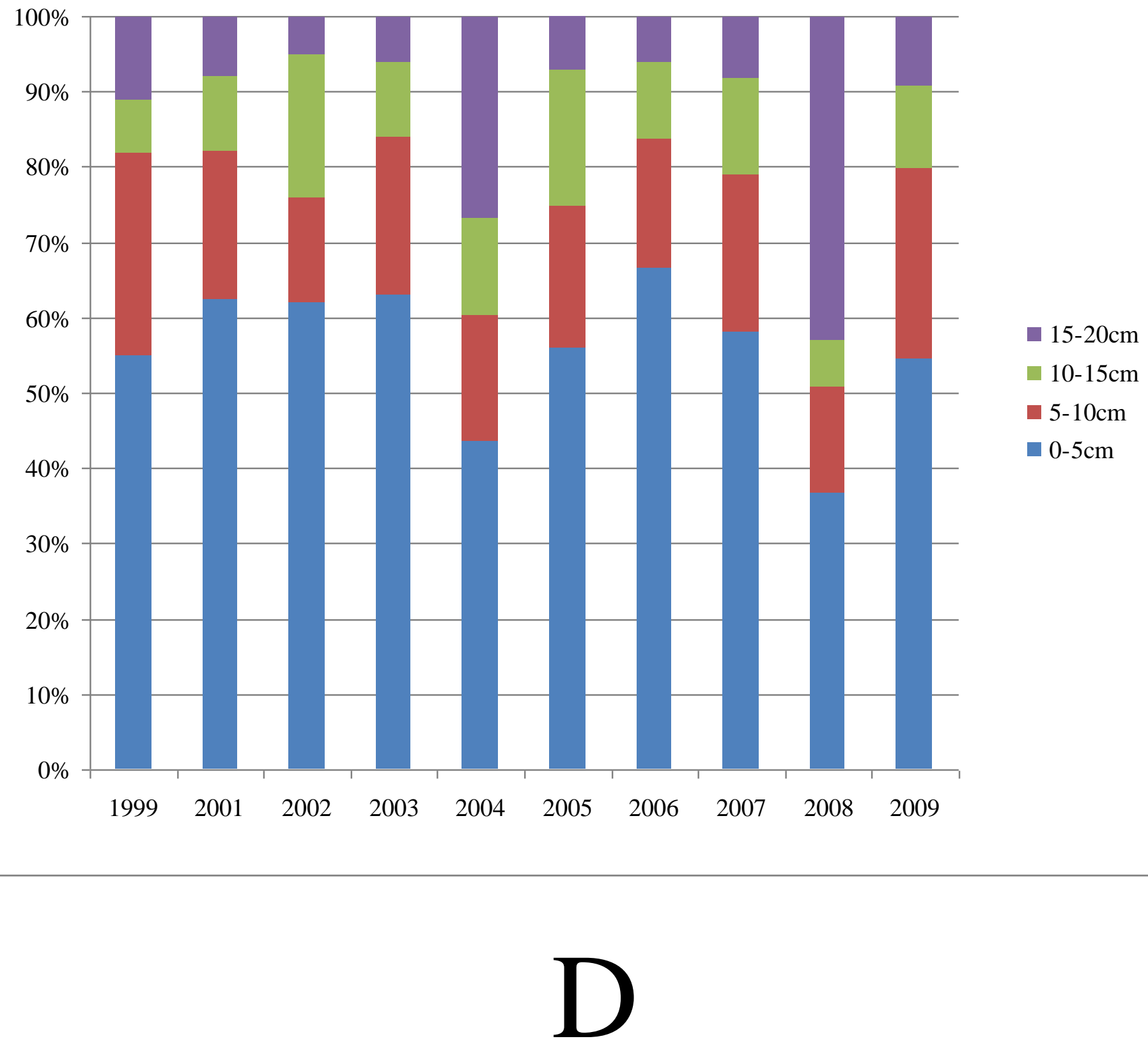

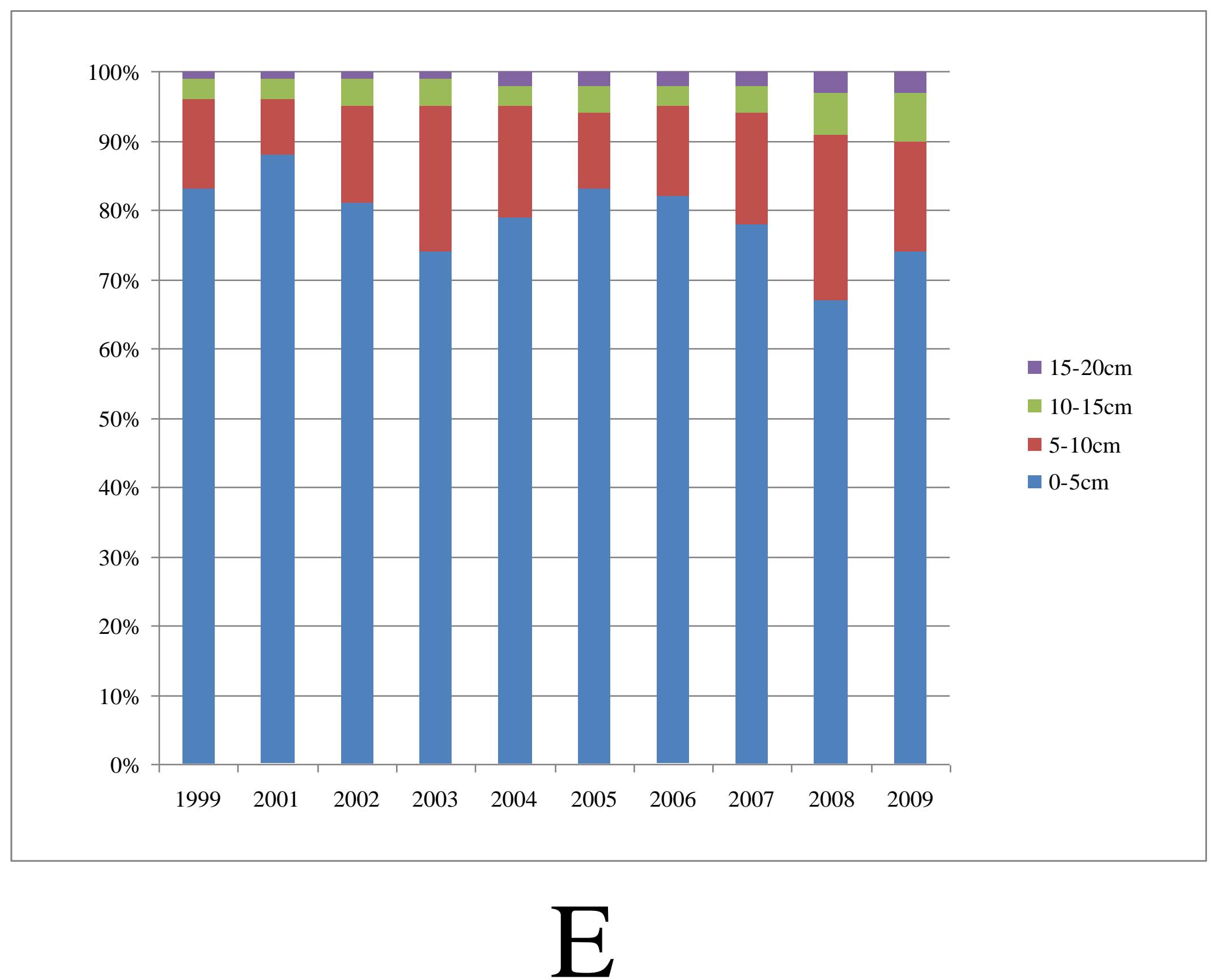


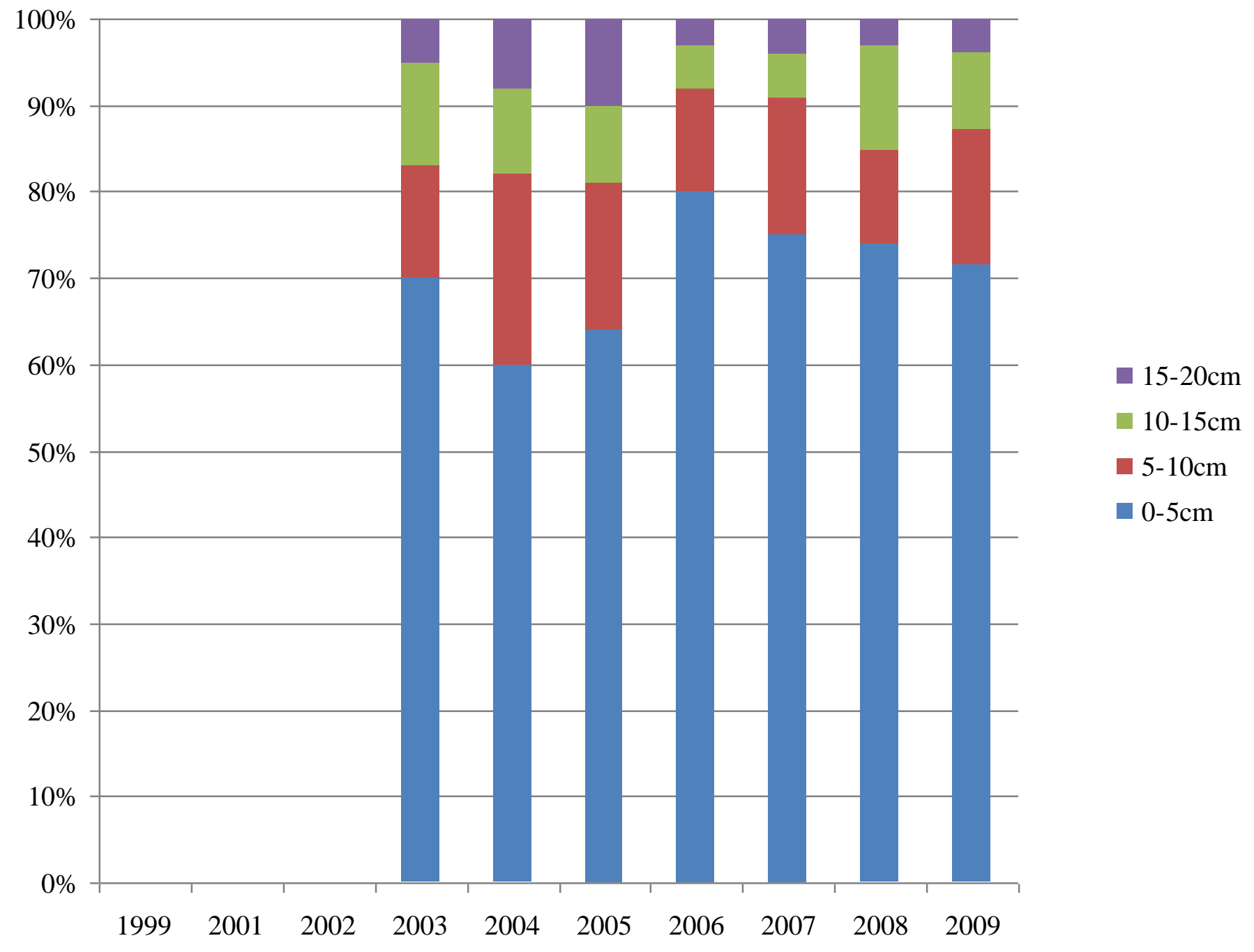

F 


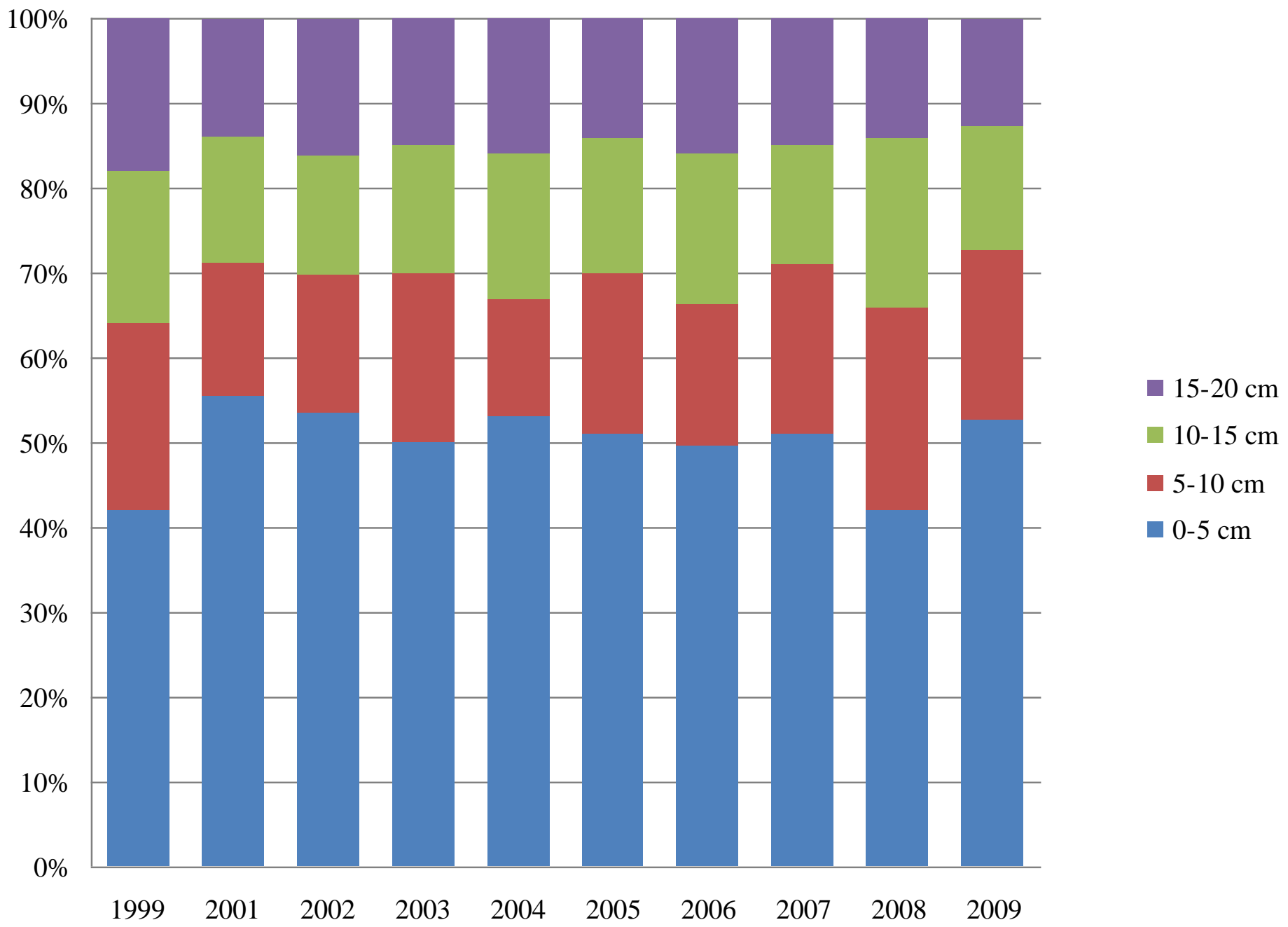

A 


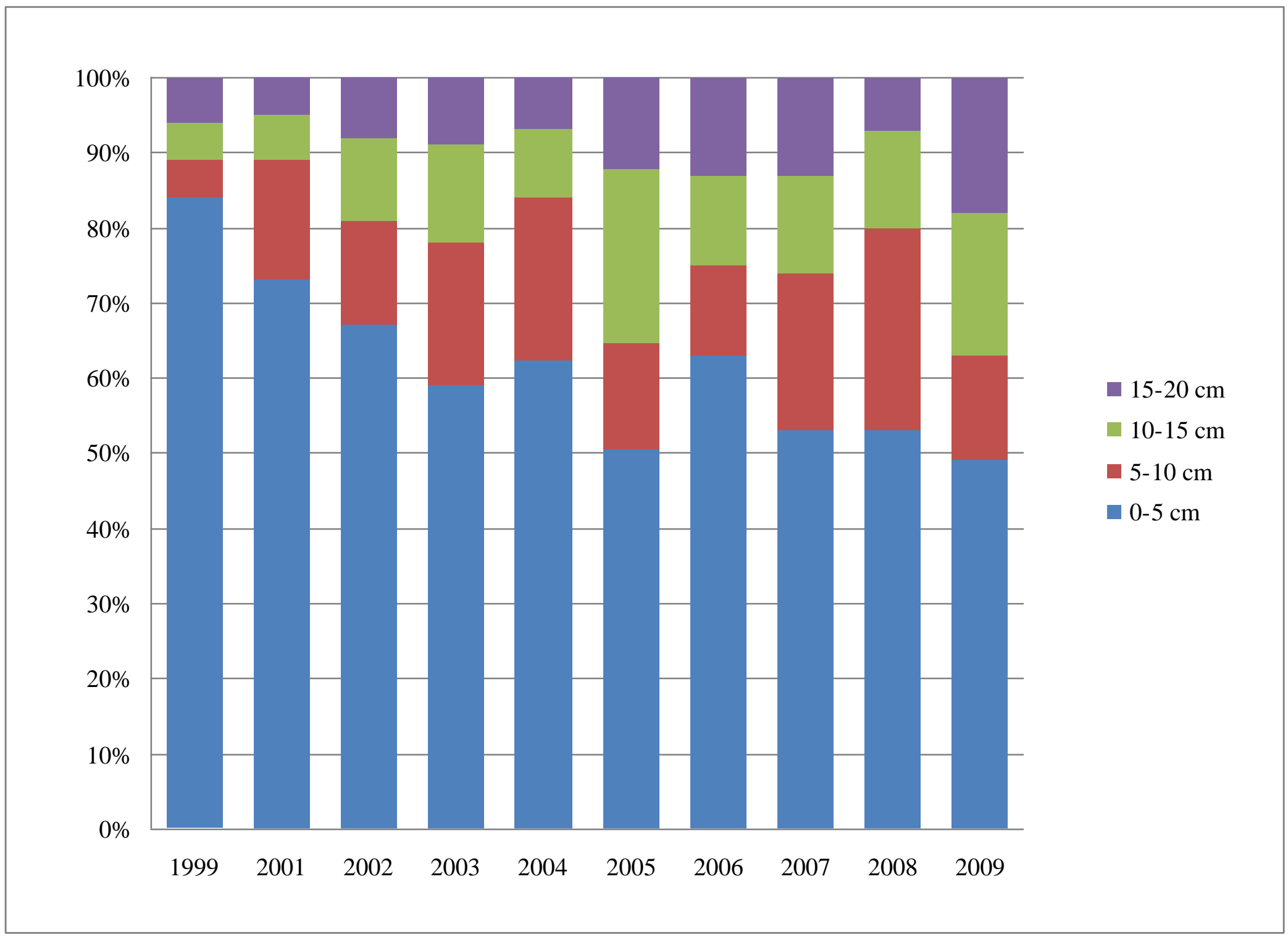

B 

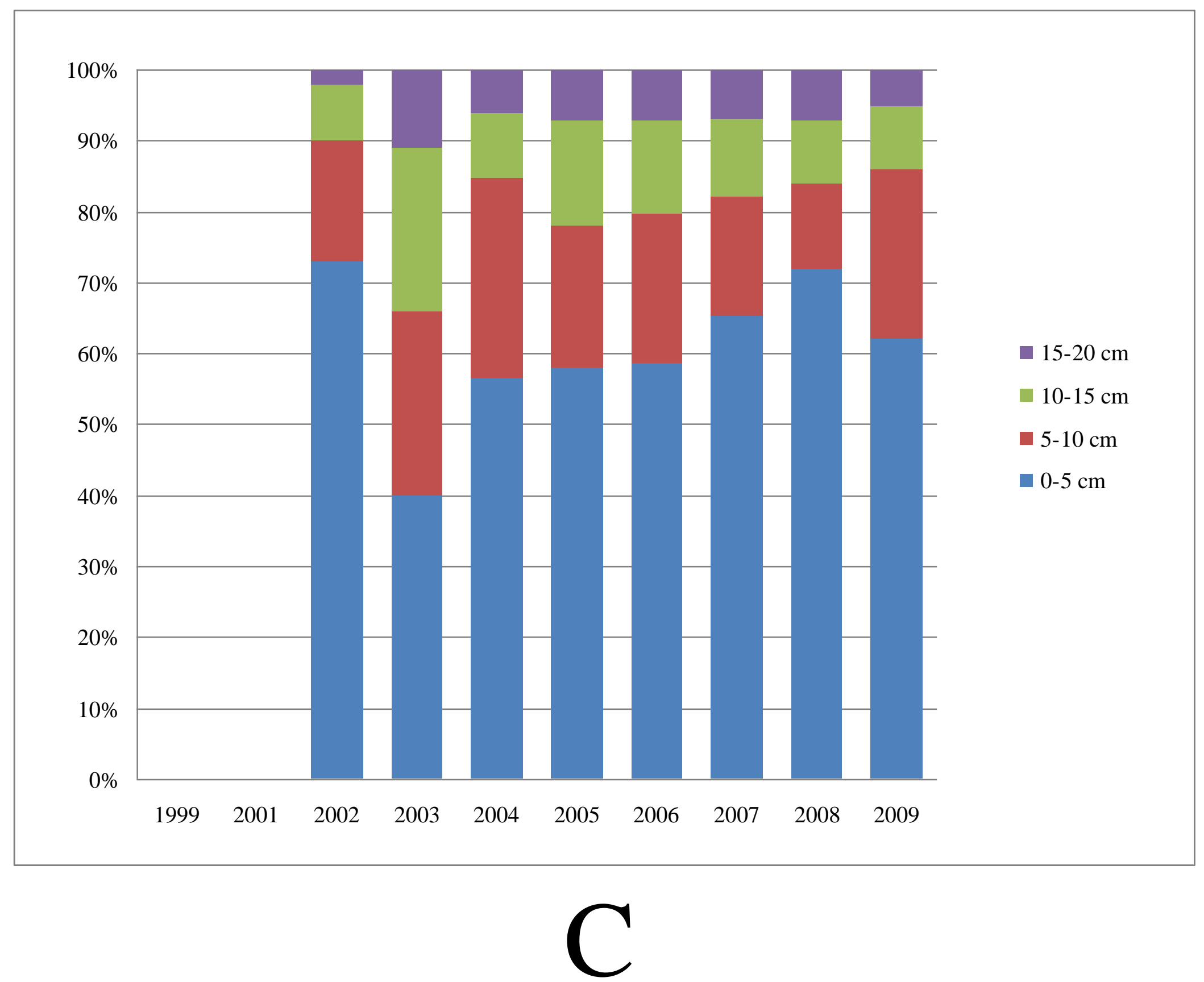

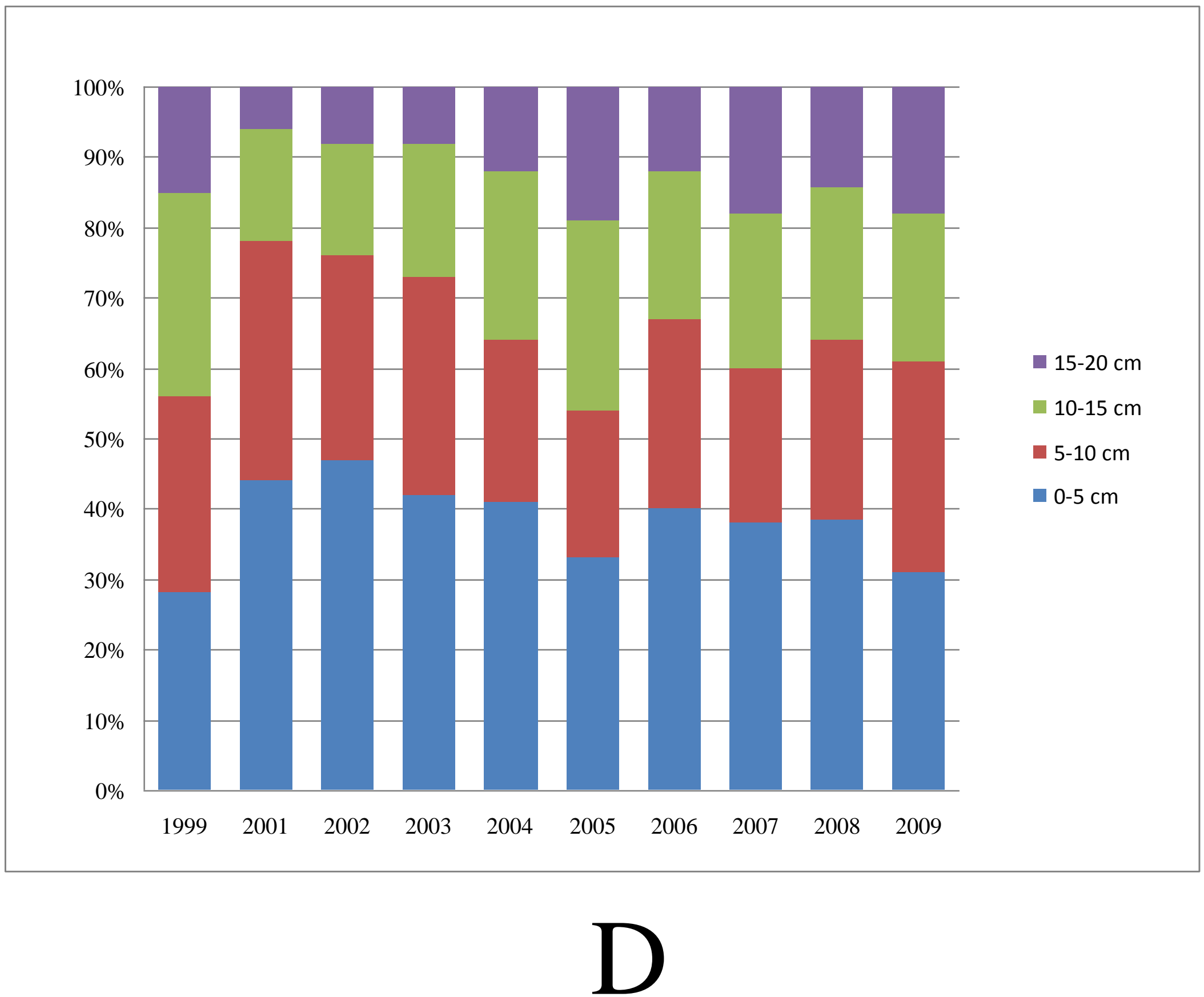

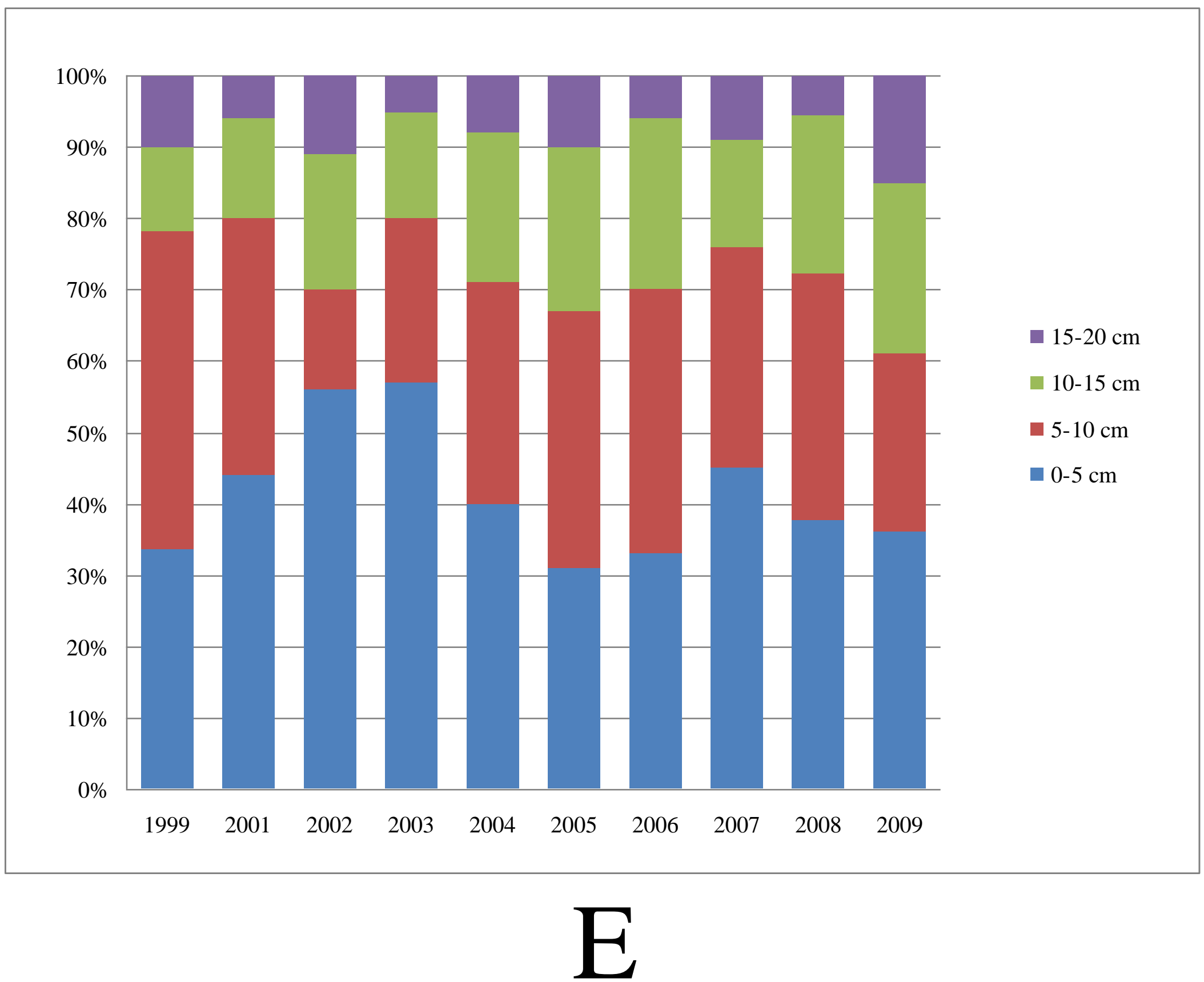

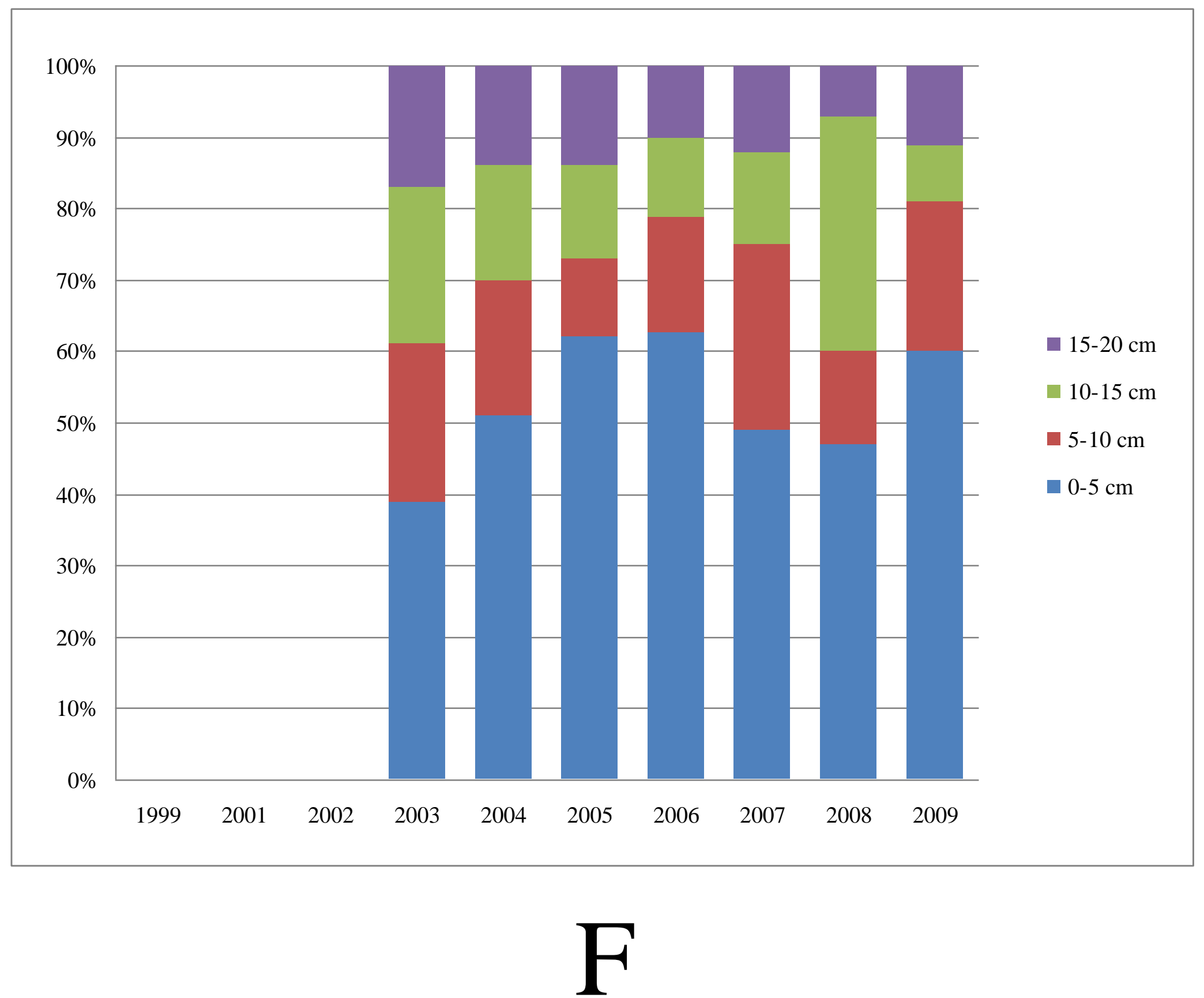

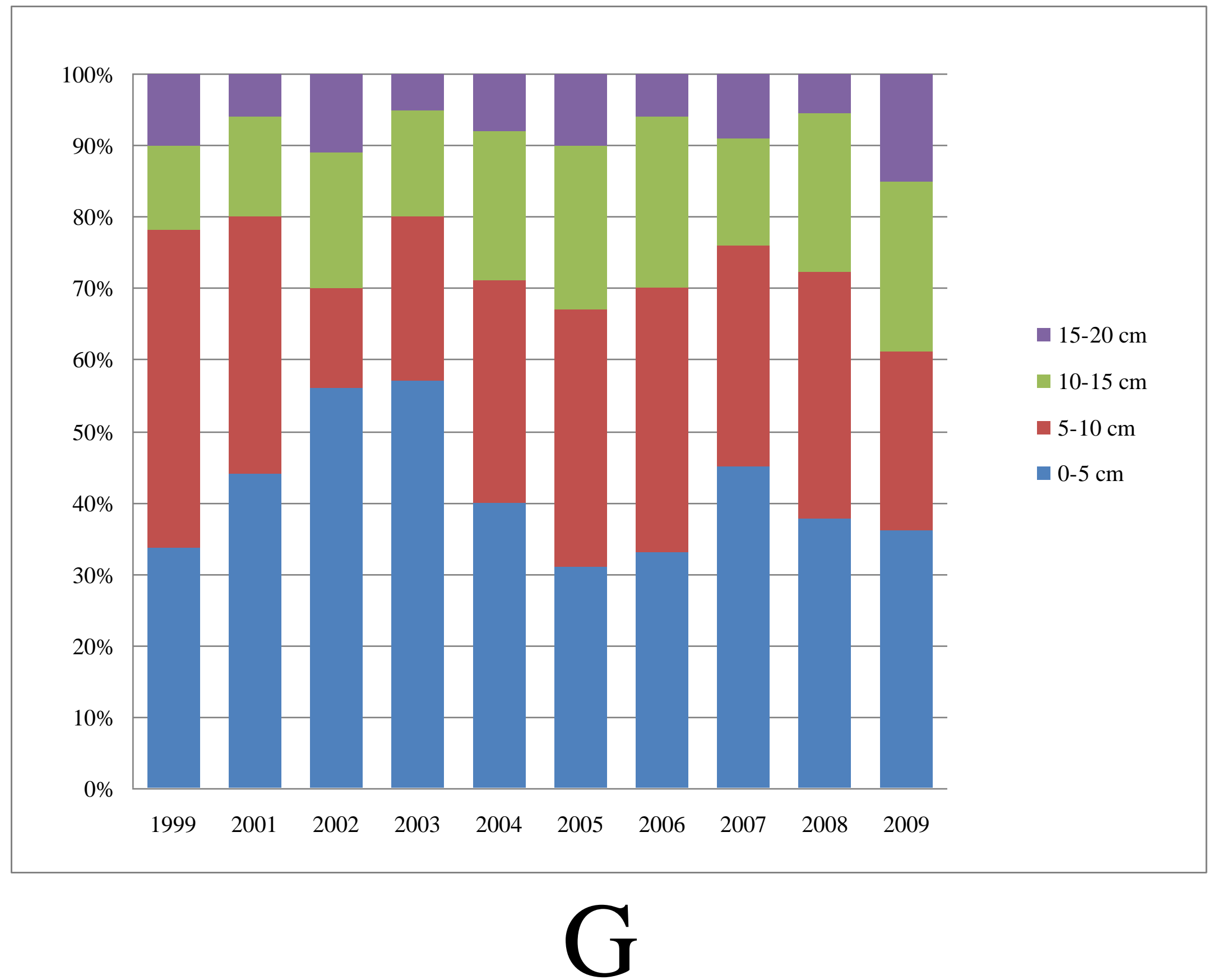


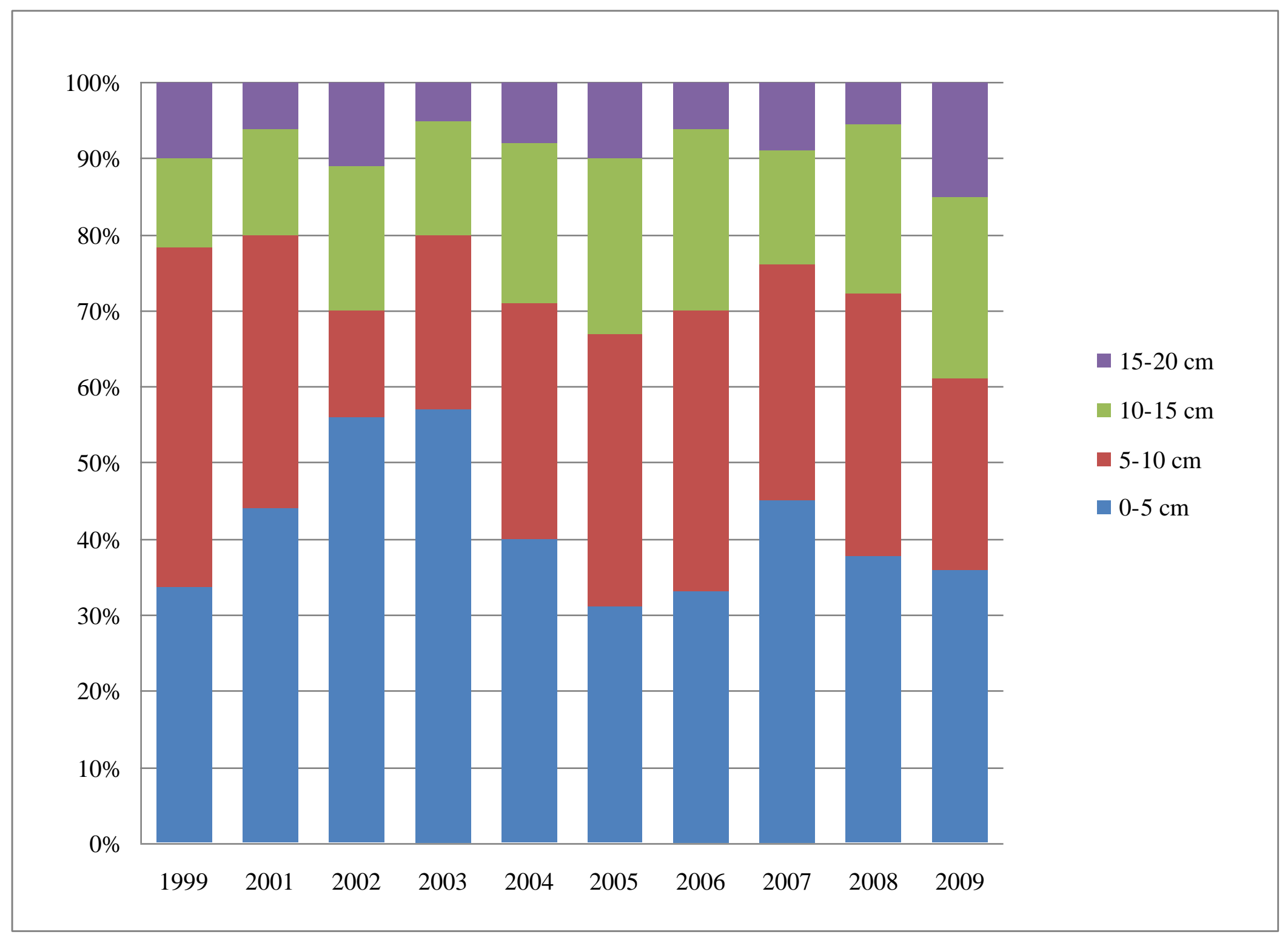

\section{$\mathrm{H}$}




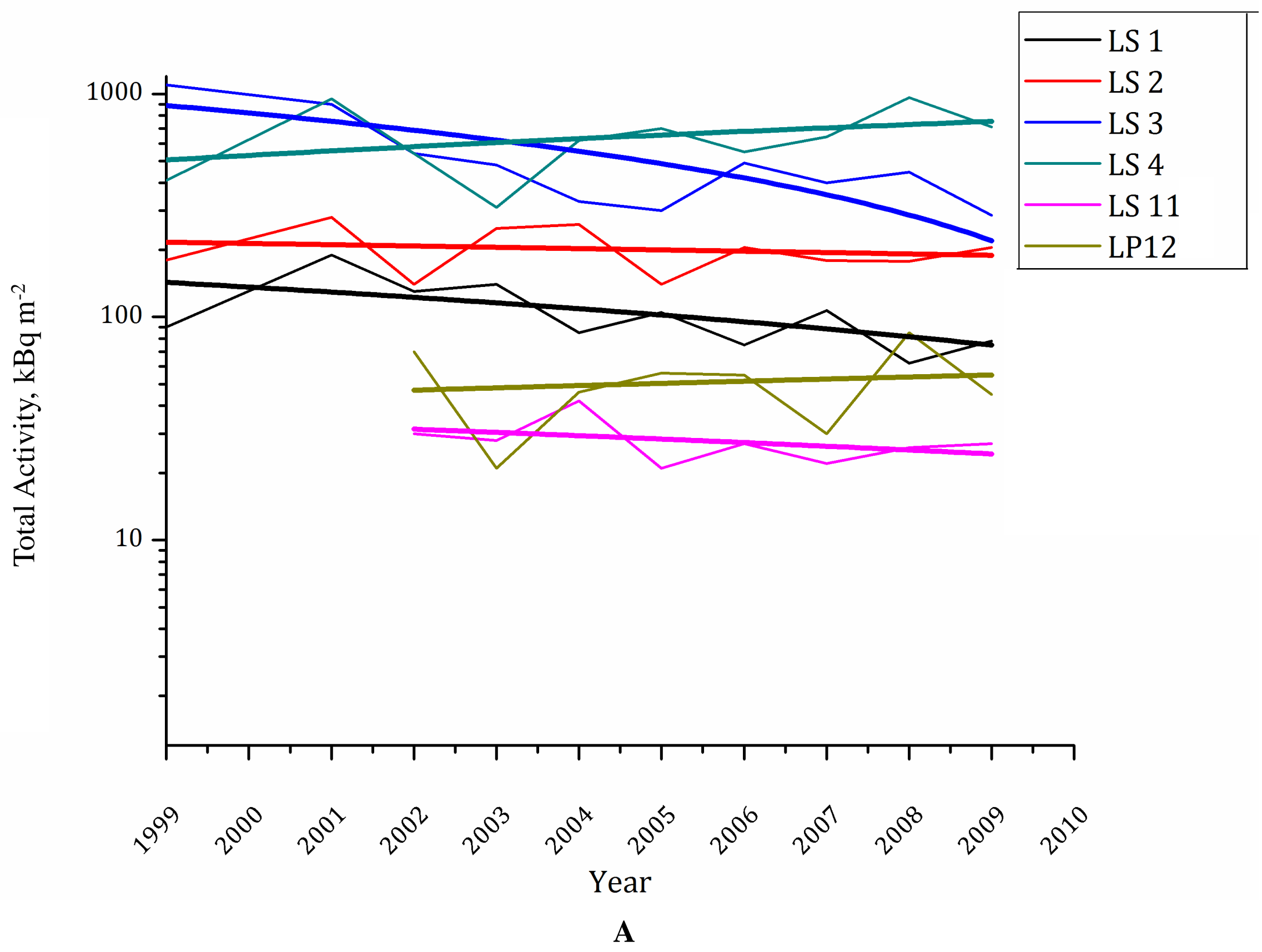




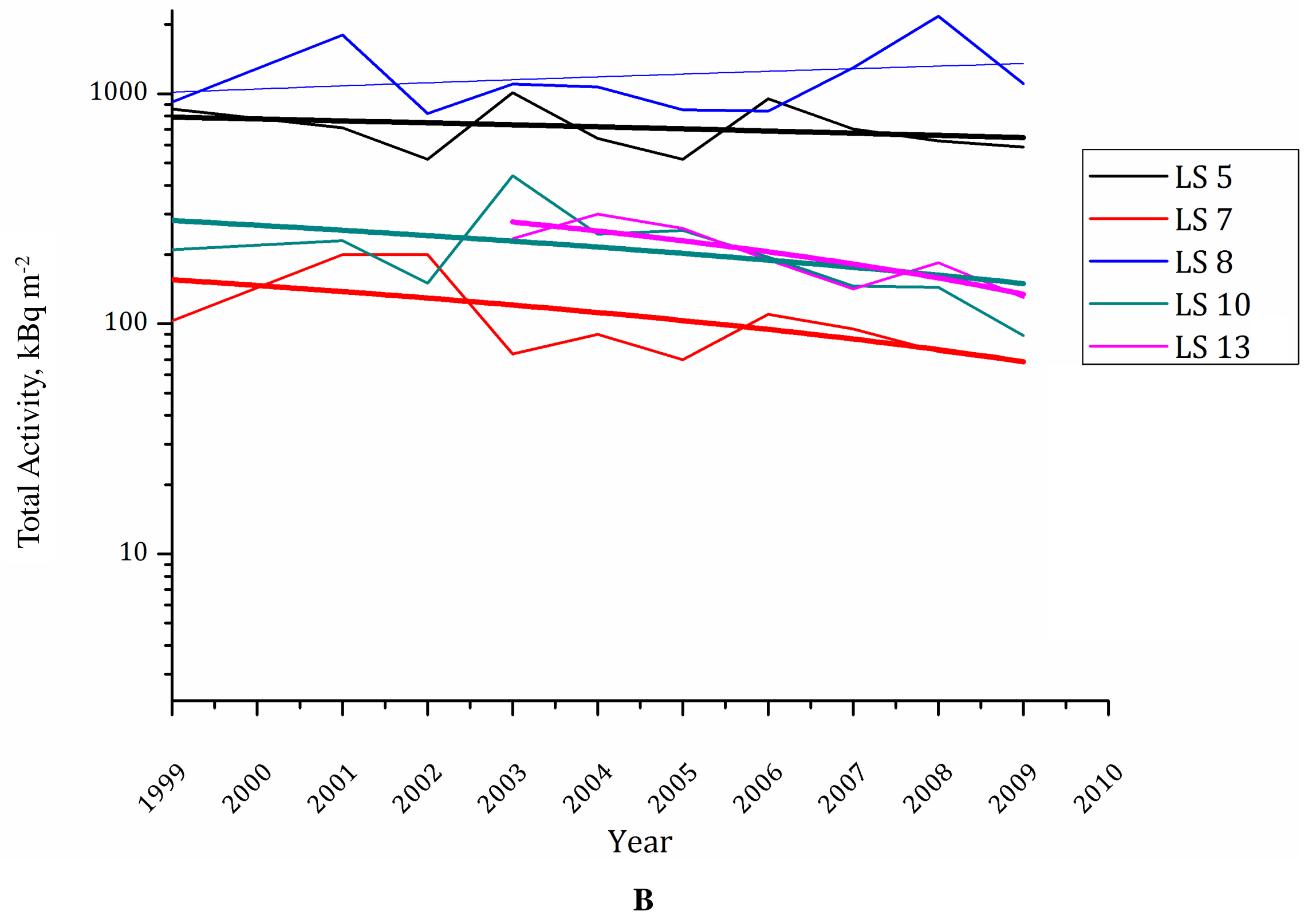




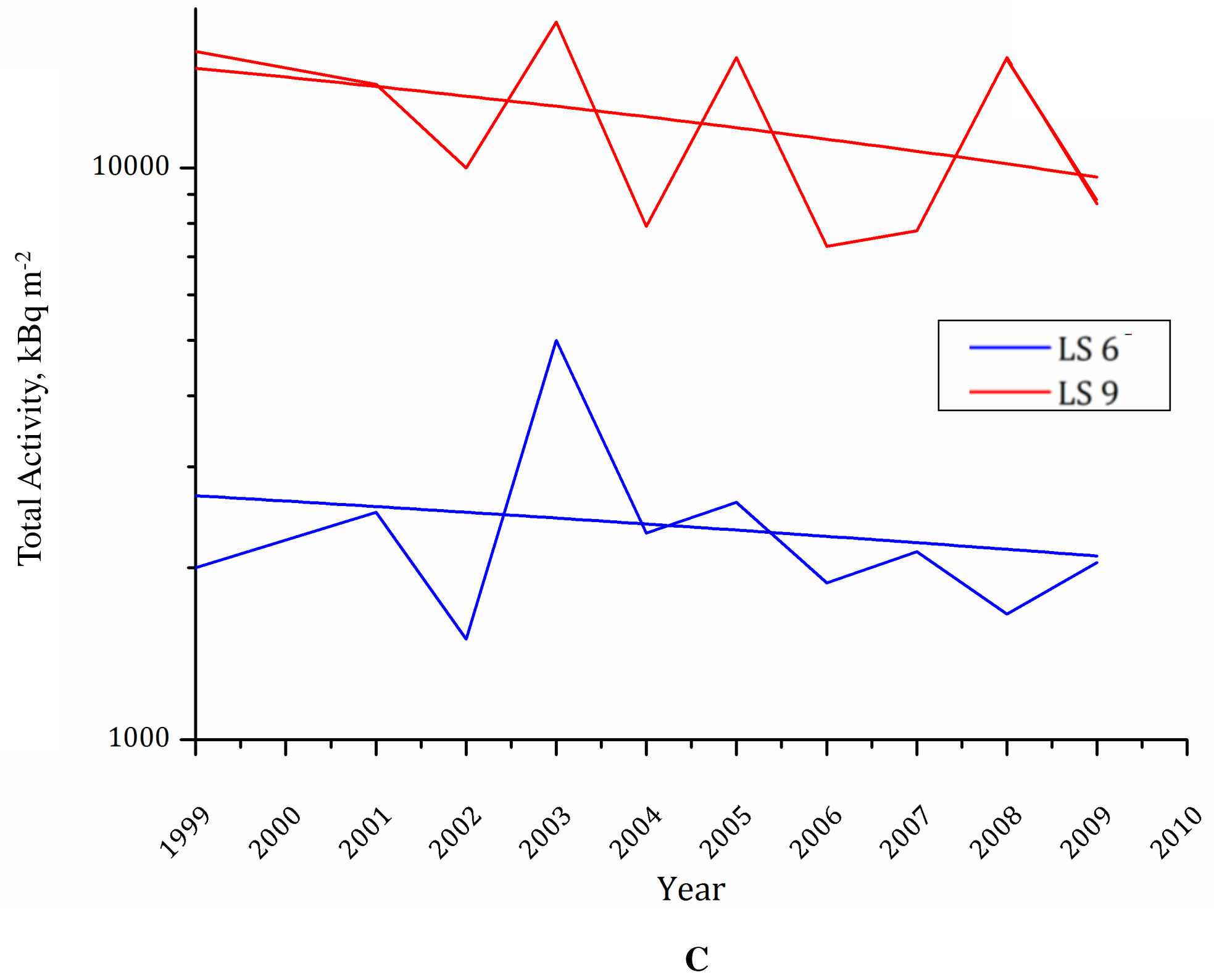




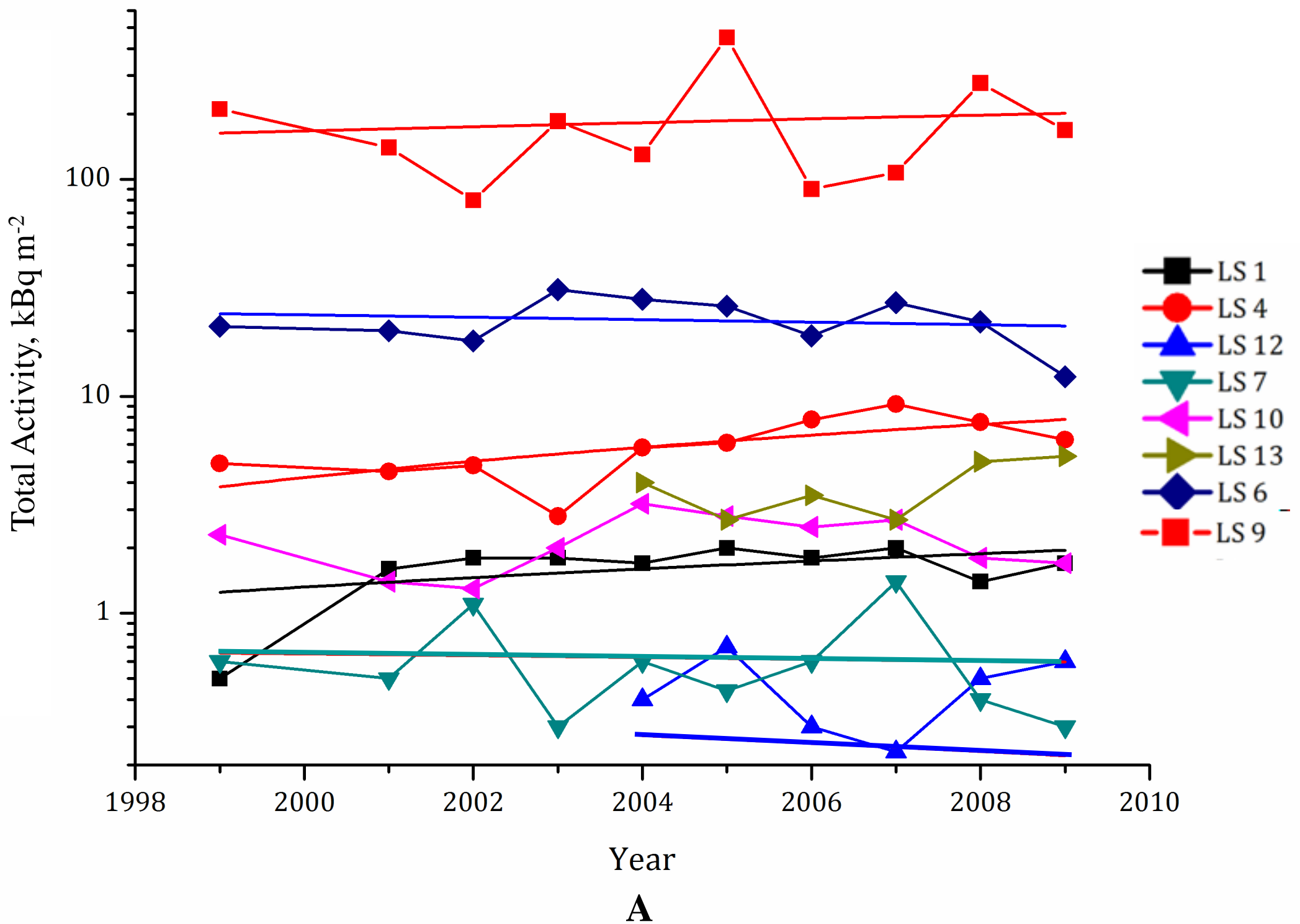




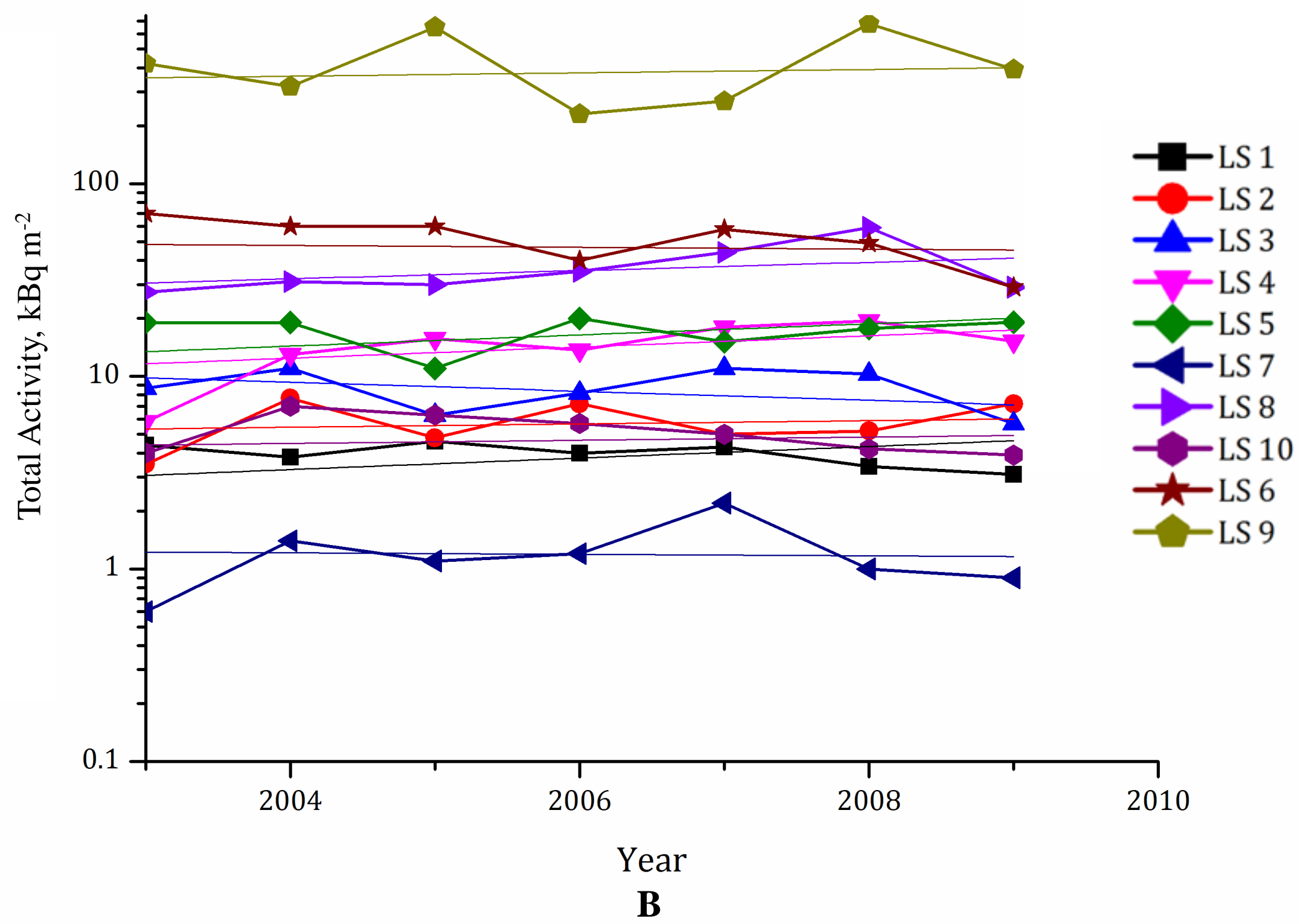




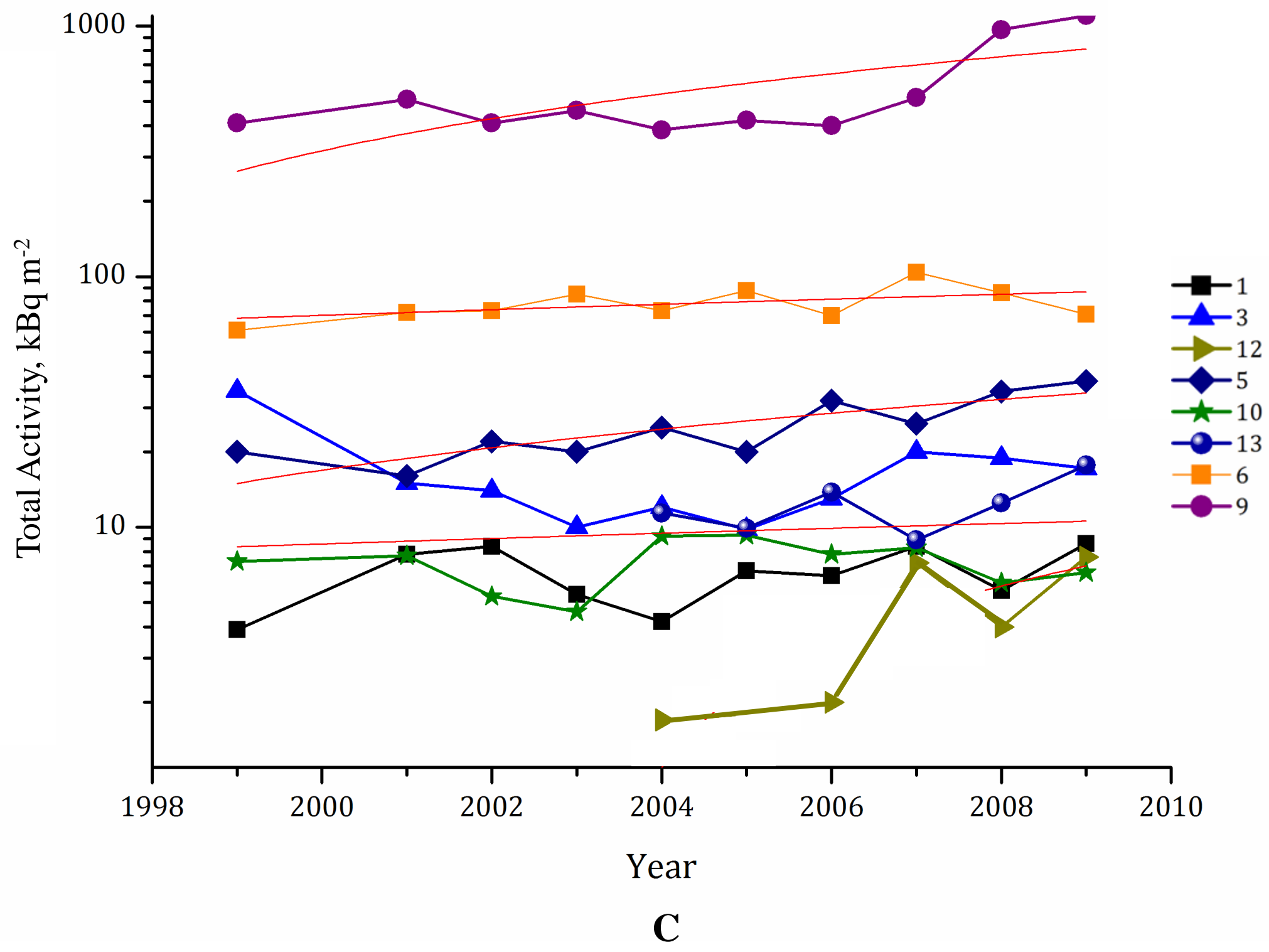




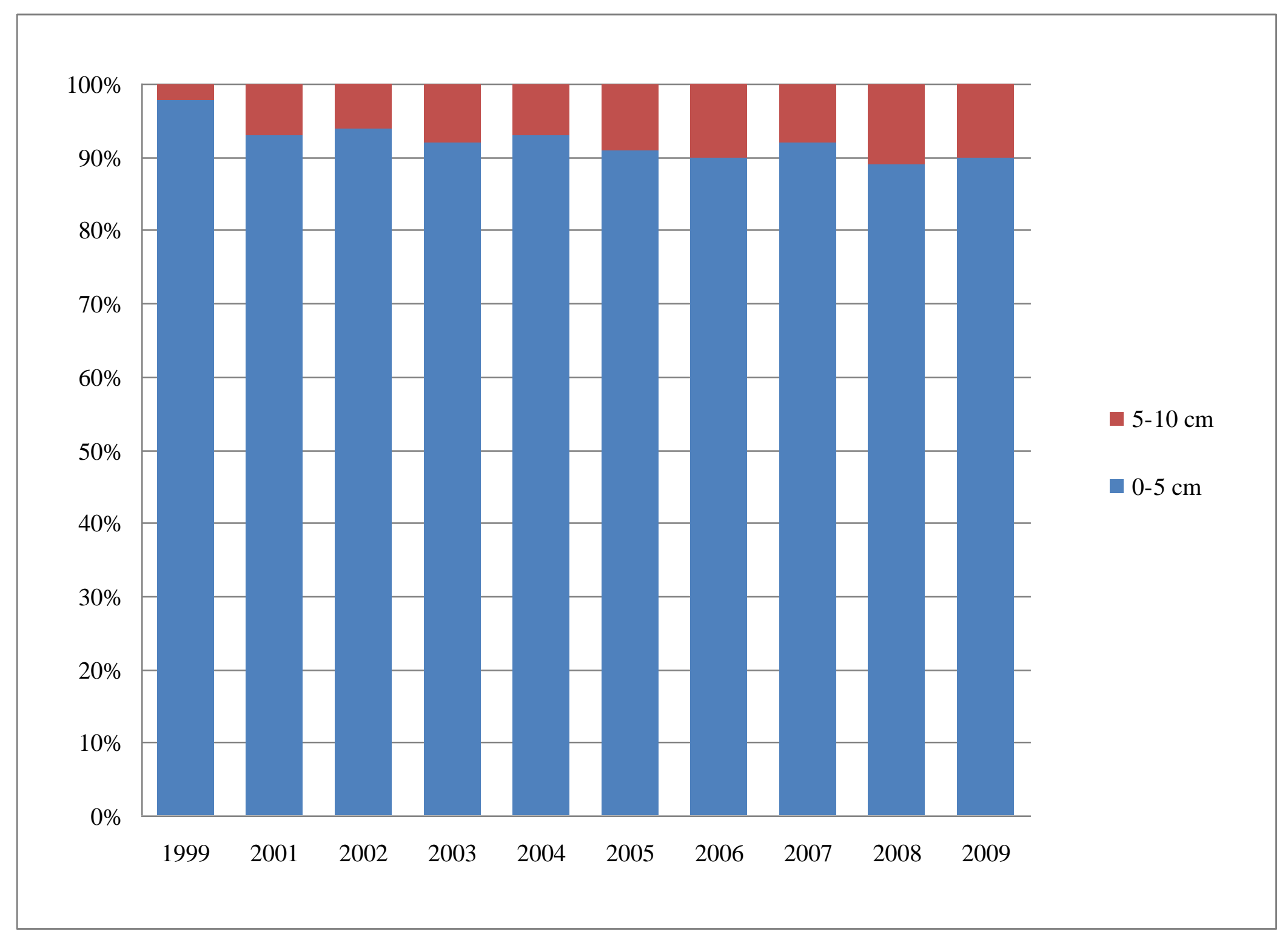

A 


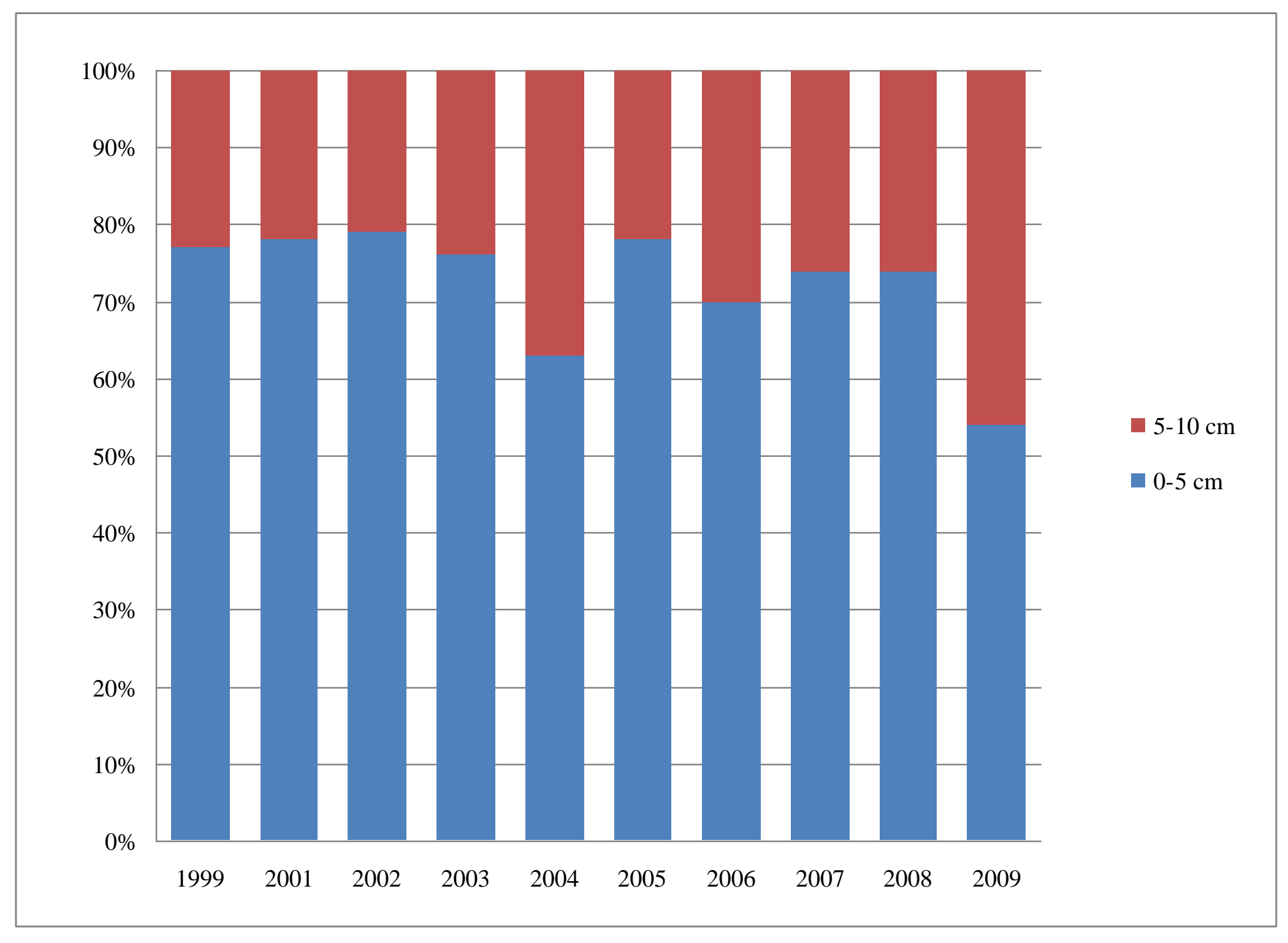

\section{B}



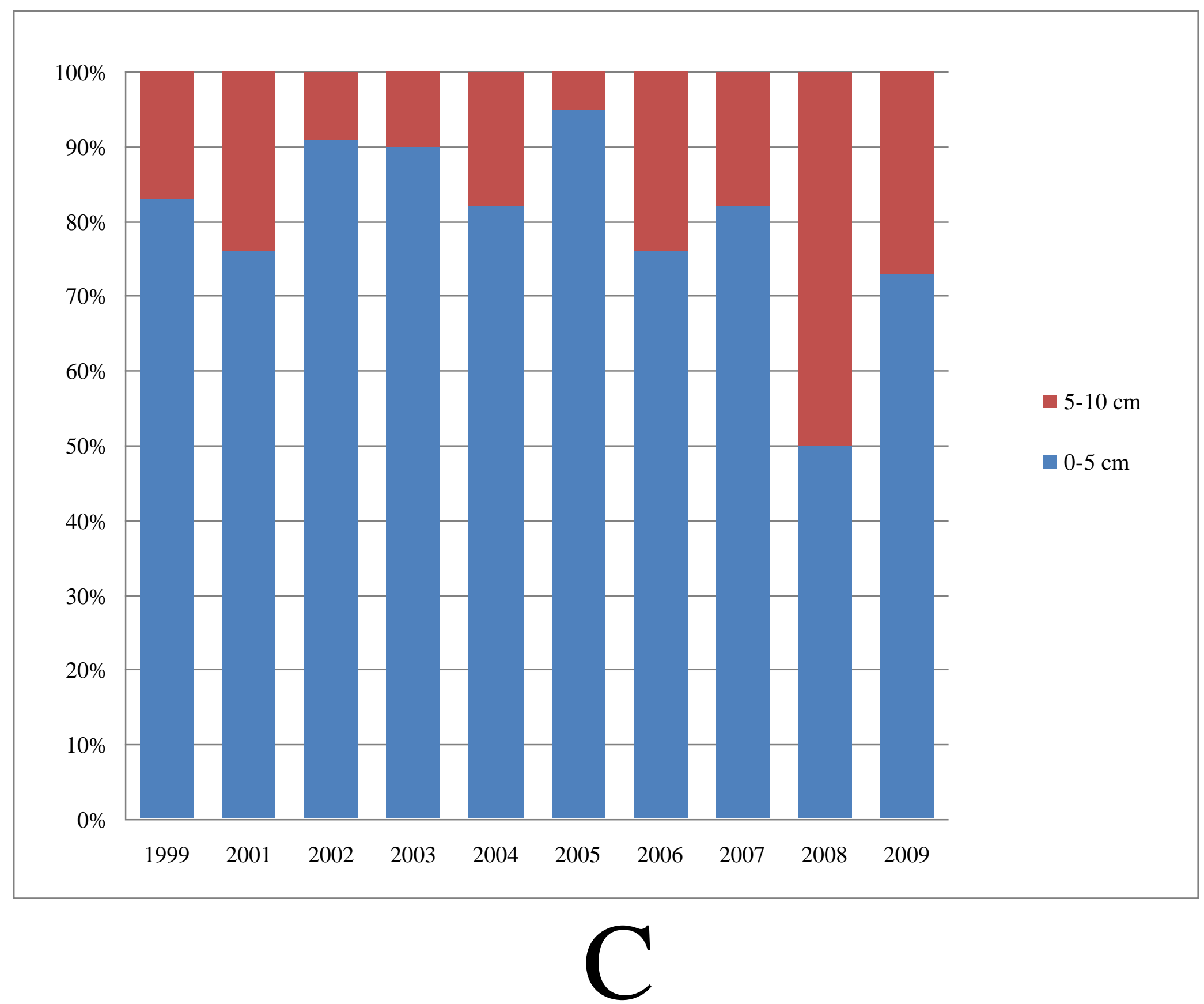

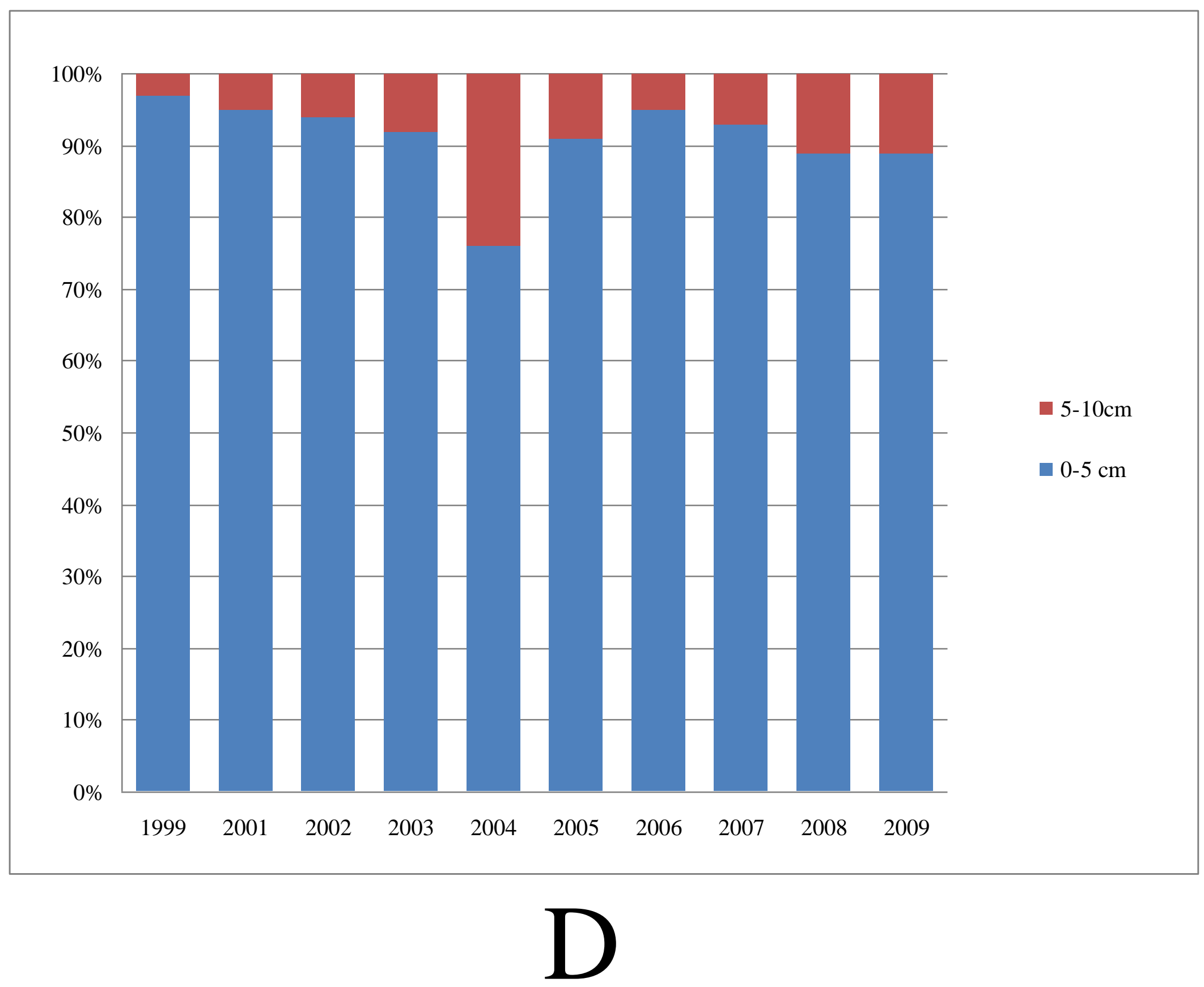

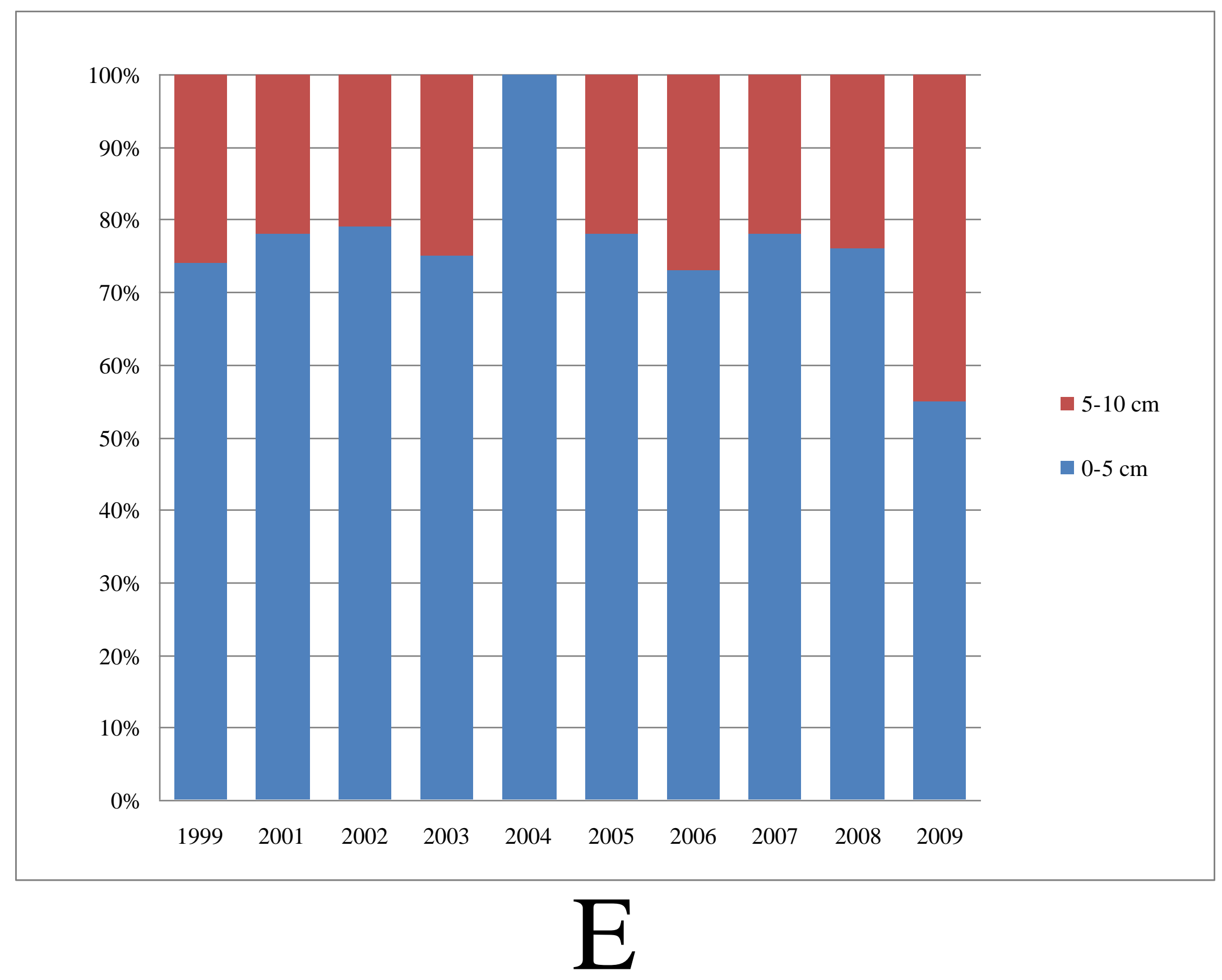

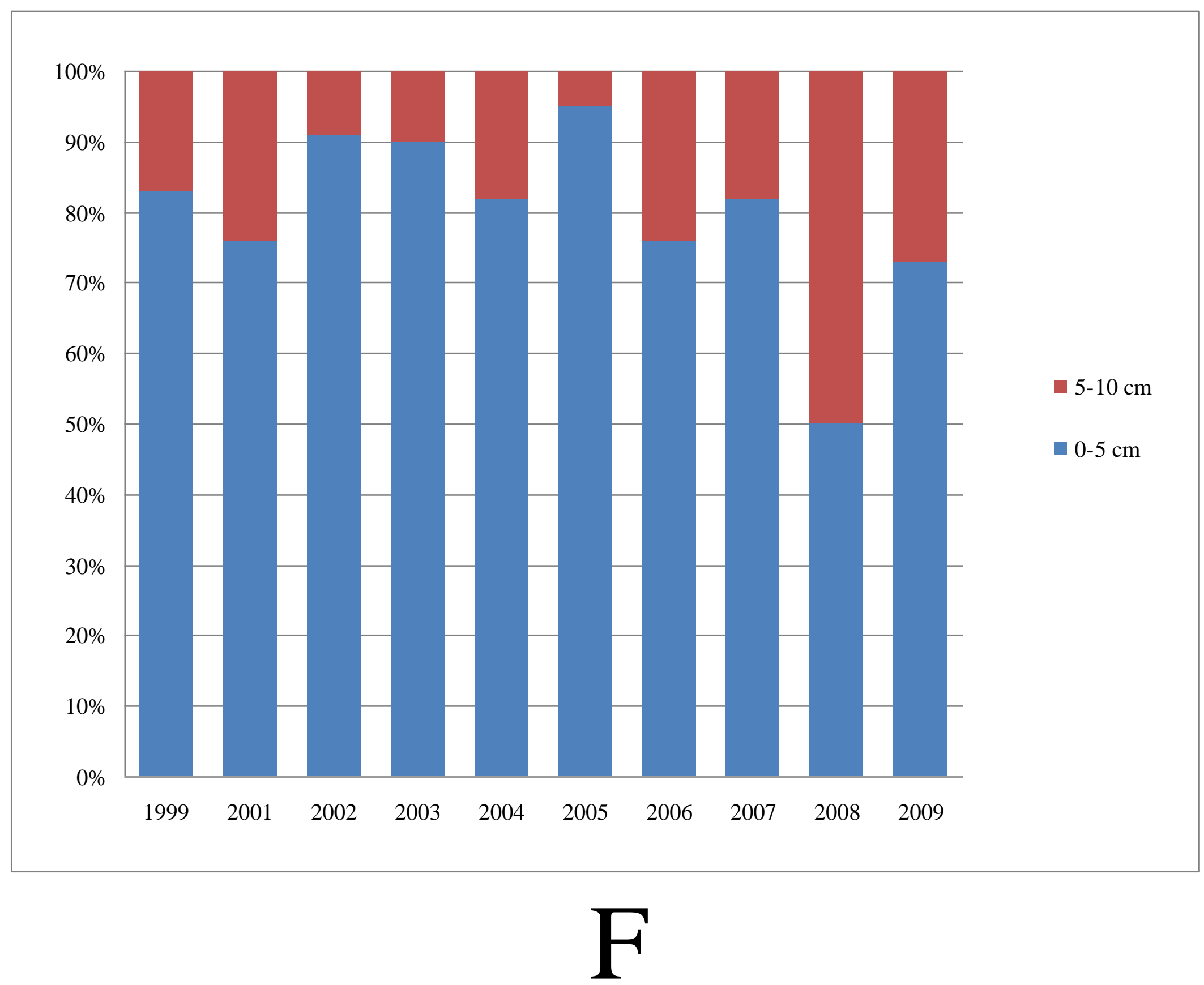

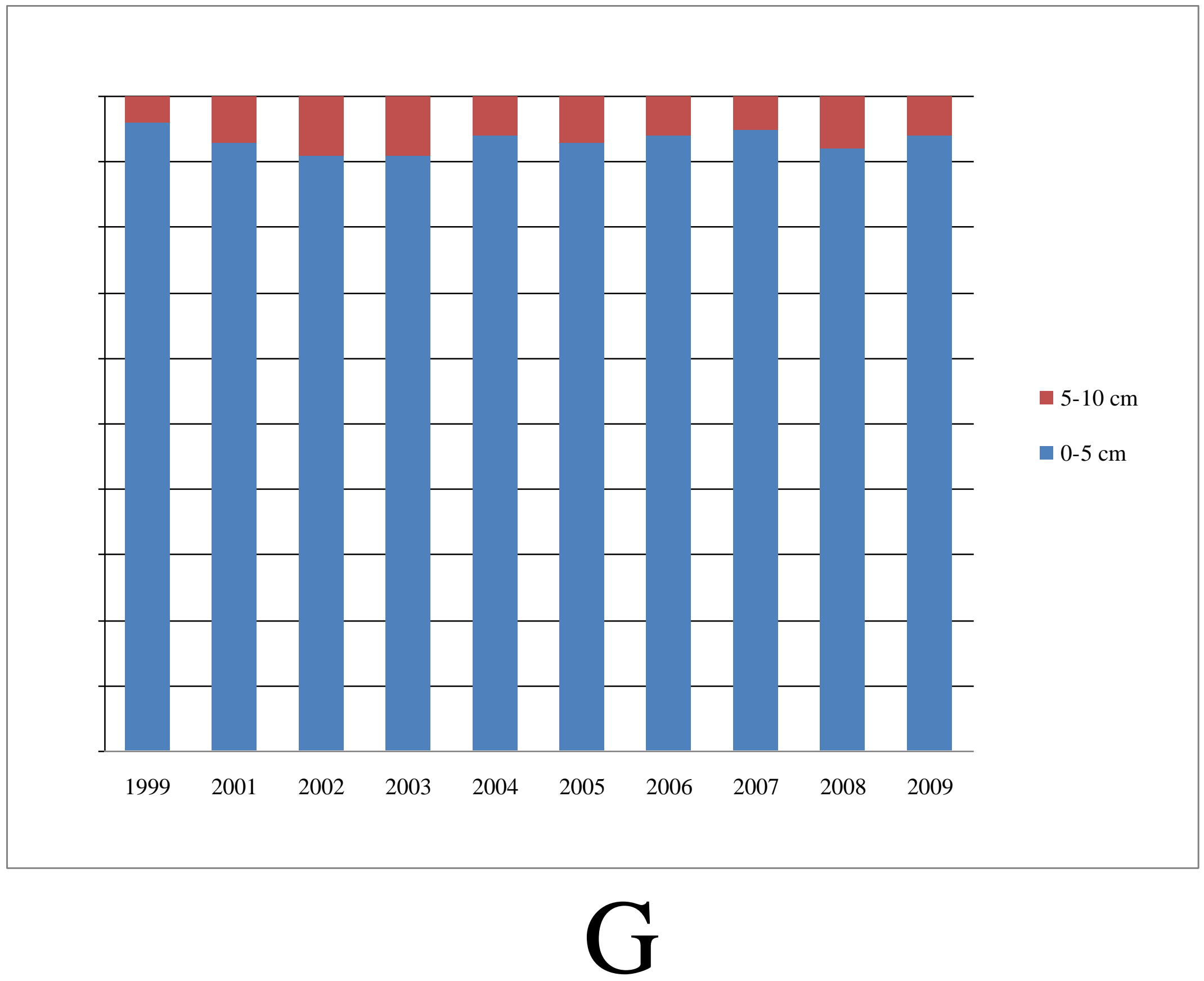

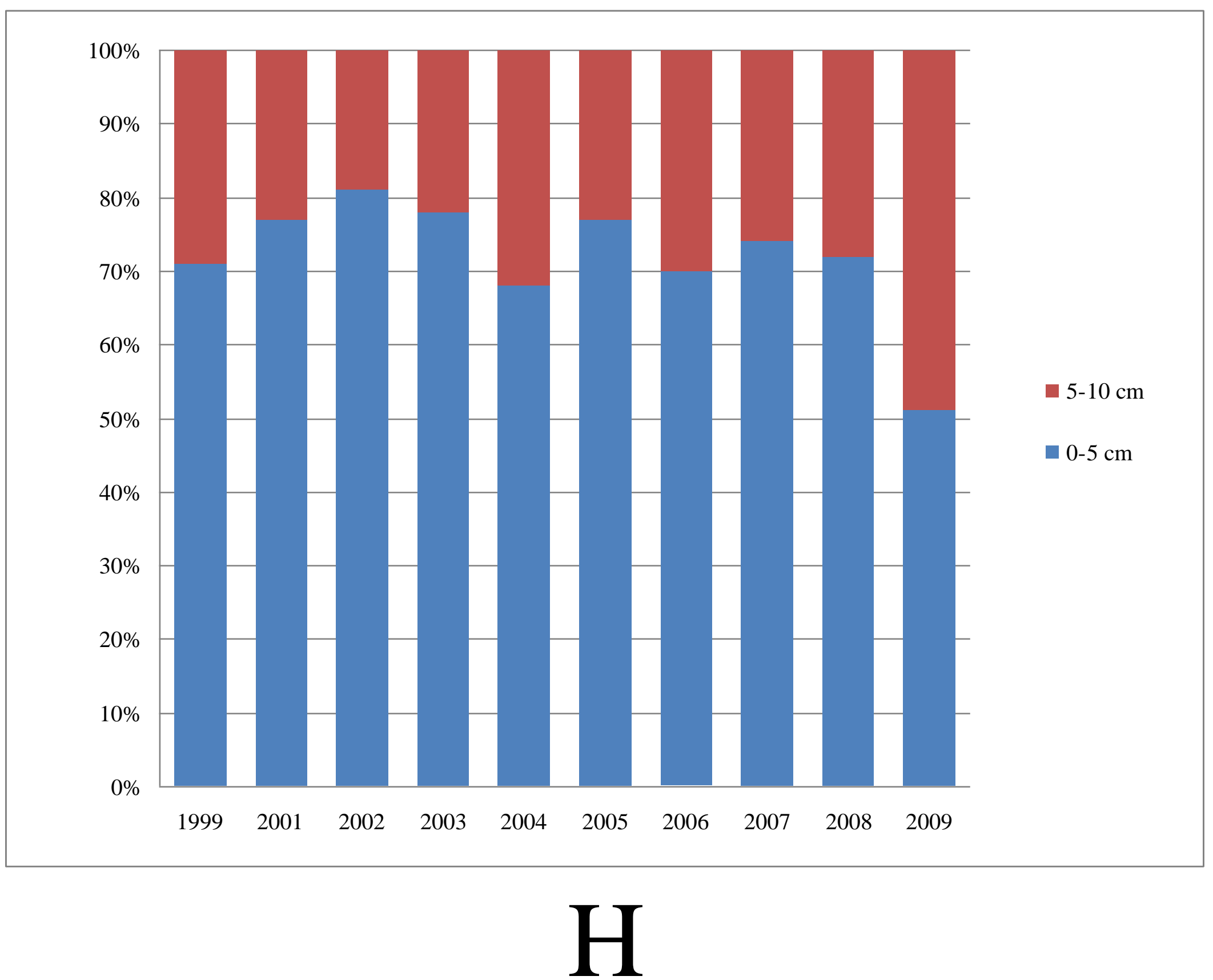

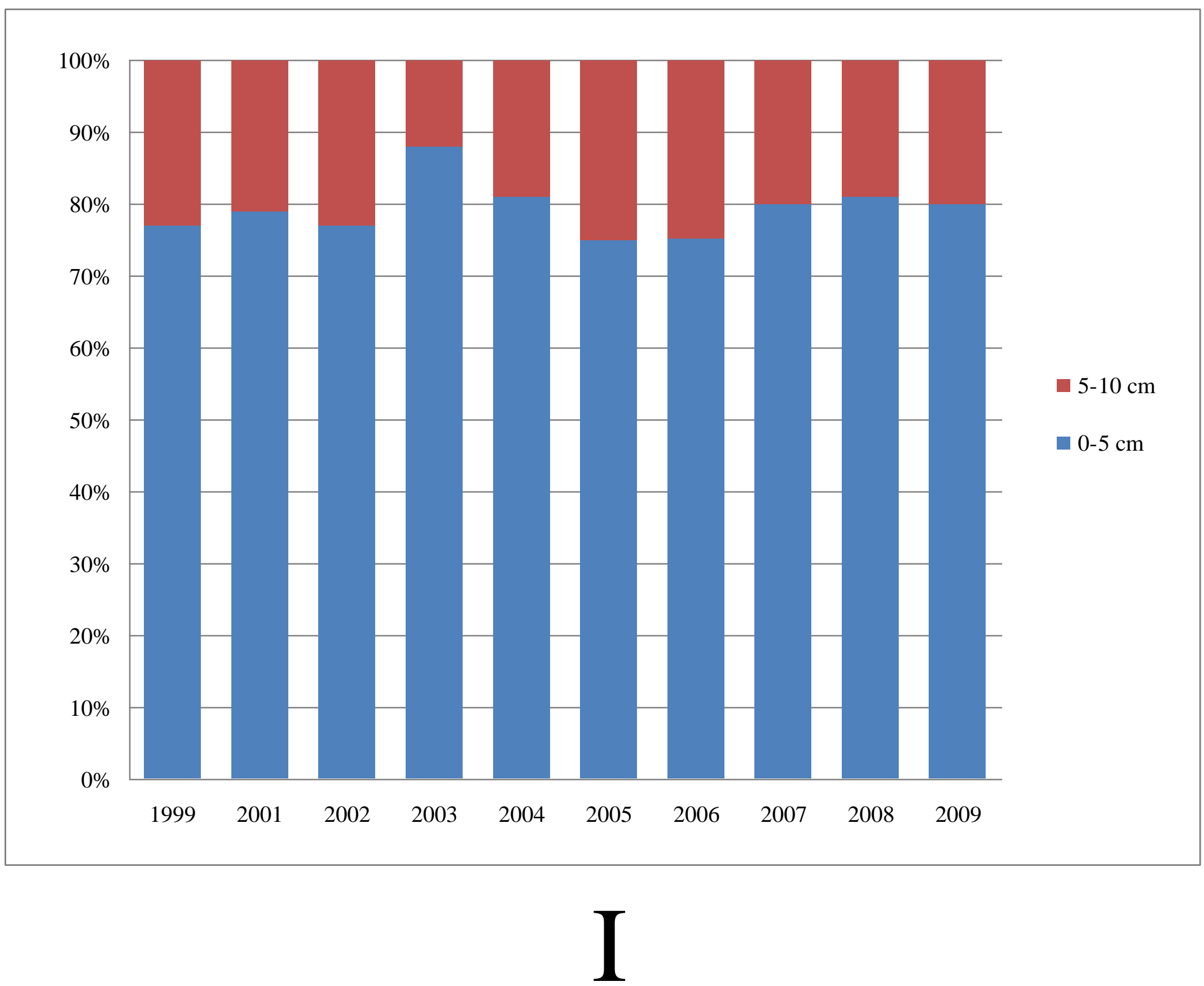


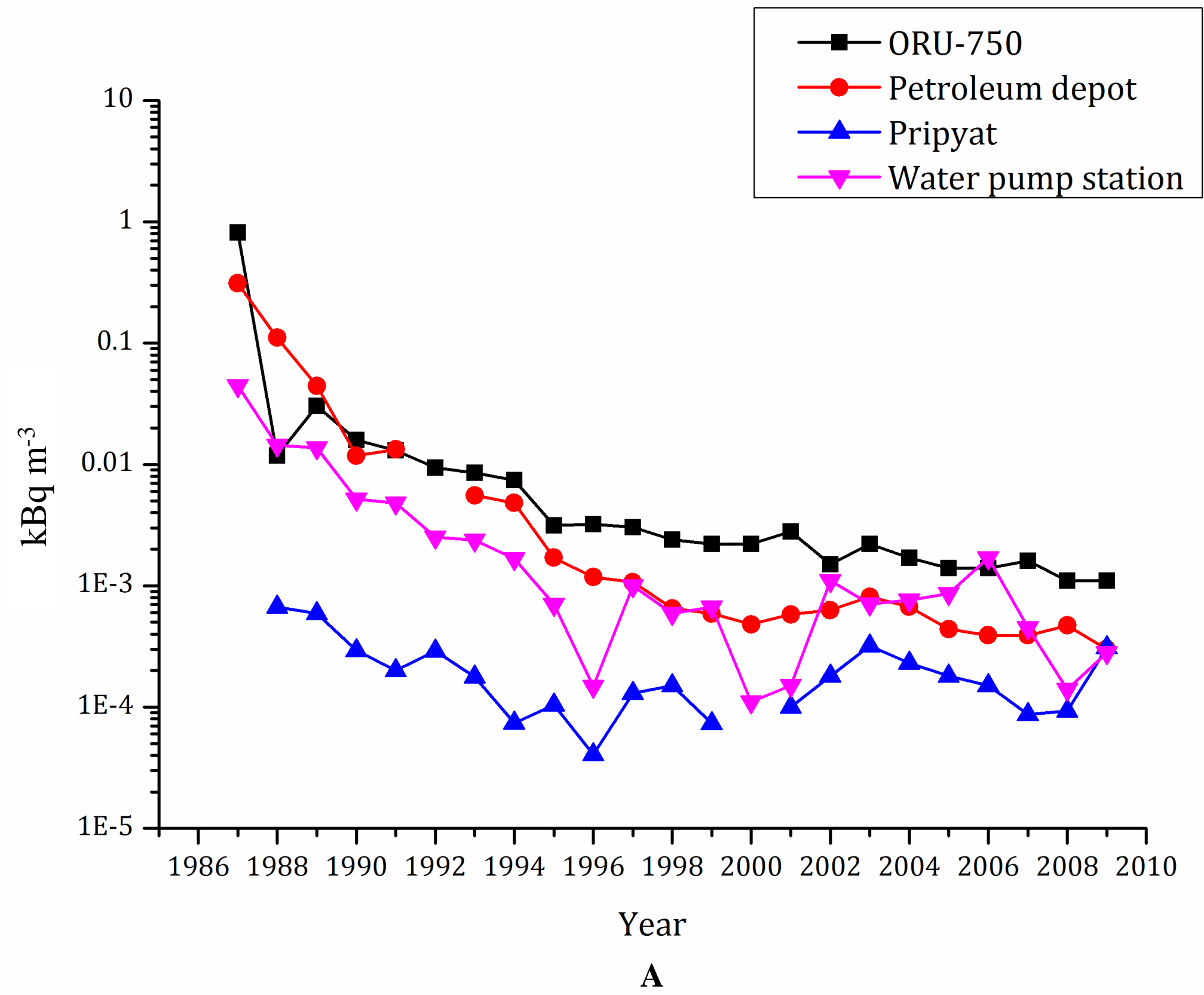




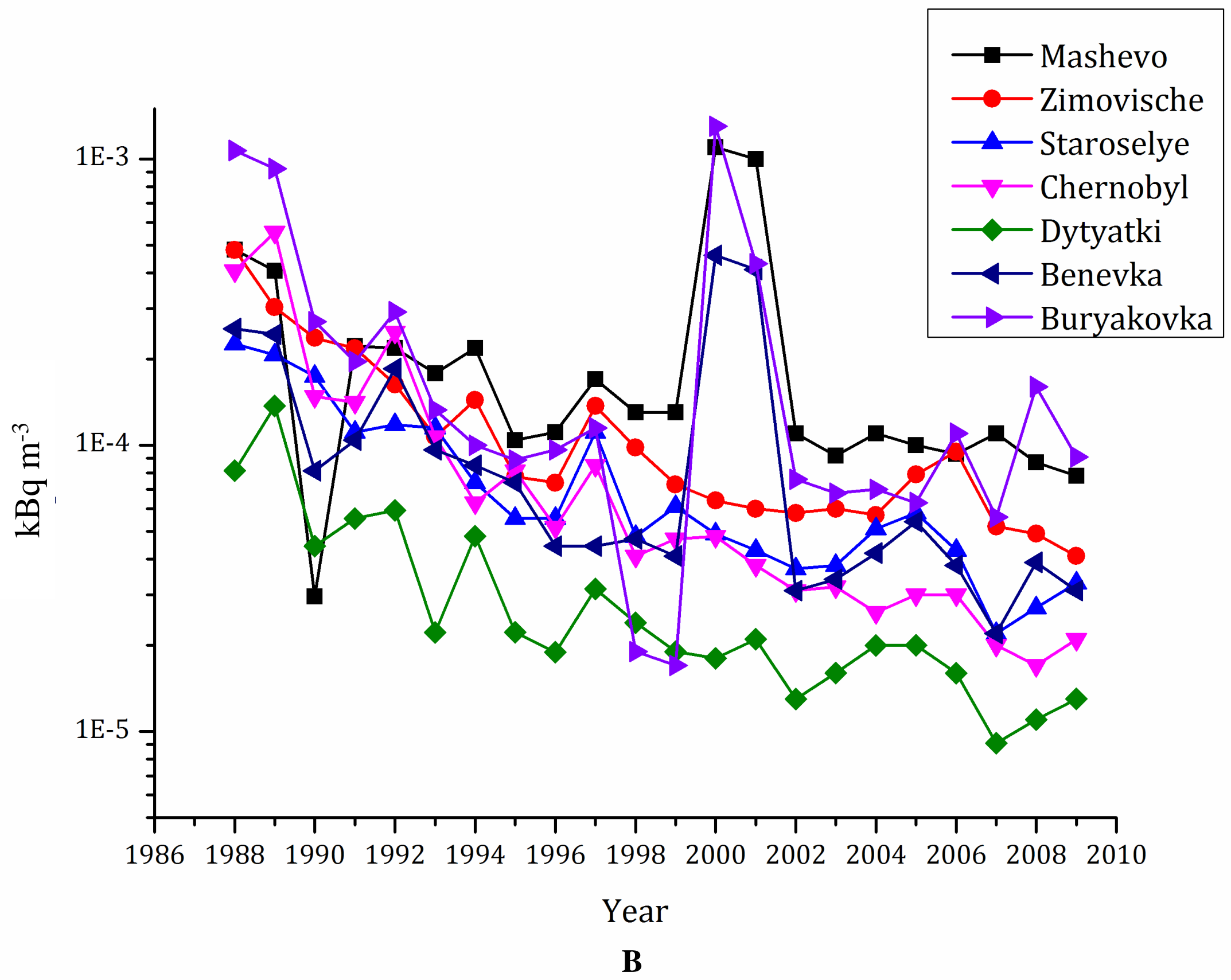




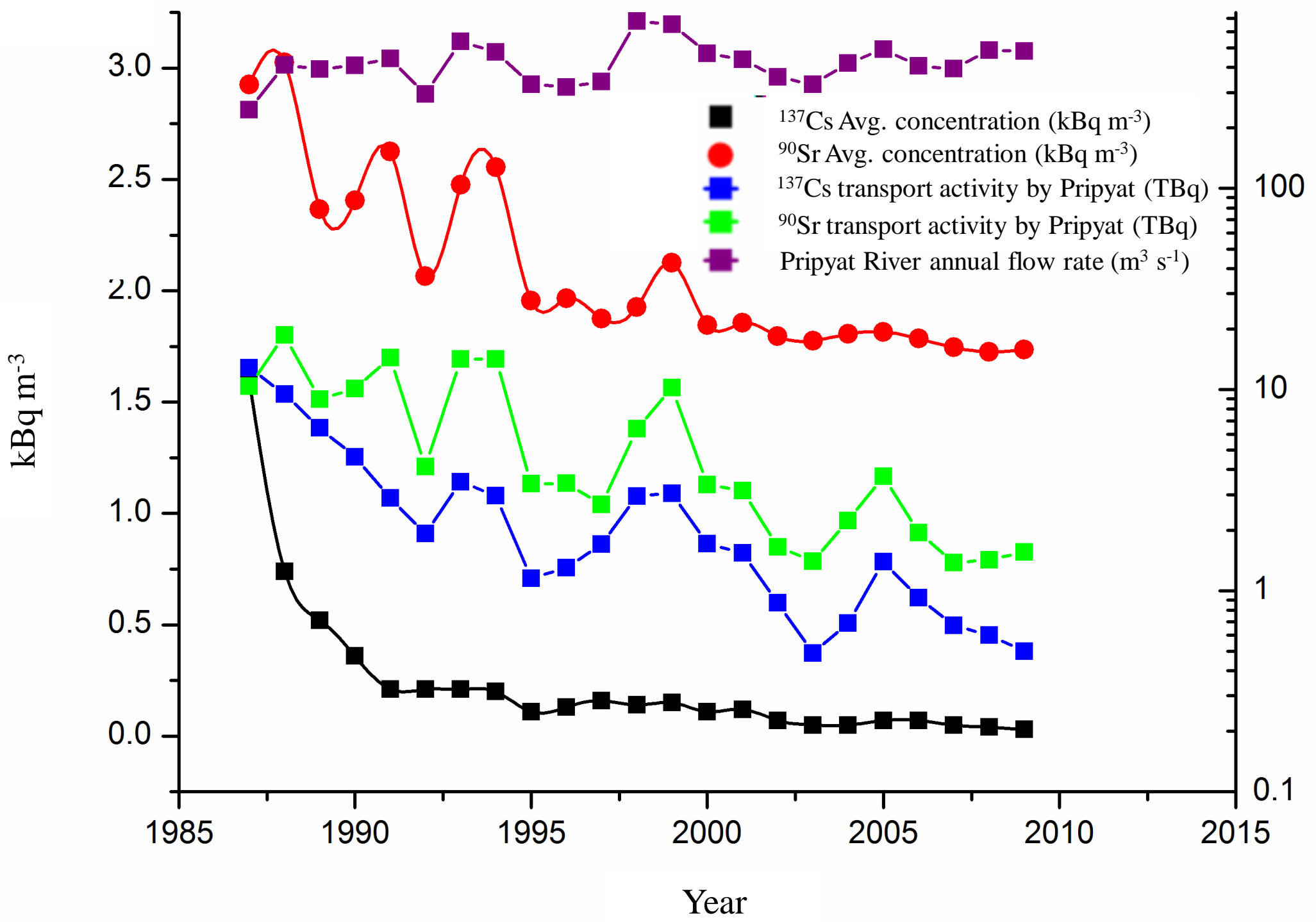

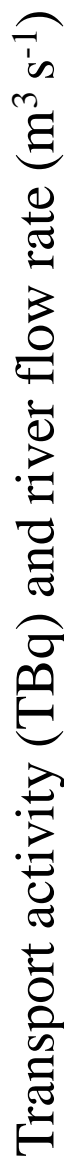


Table 1. Inventory of major long-lived radionuclides in the core of the ChNPP reactor unit 4 (Borovoy et al. 1990).

\begin{tabular}{|c|c|c|c|c|}
\hline \multirow[t]{2}{*}{ Radionuclide } & \multirow{2}{*}{\multicolumn{2}{|c|}{ Mass, kg }} & \multicolumn{2}{|c|}{ Activity } \\
\hline & & & $\mathbf{B q}$ & MCi \\
\hline${ }^{90} \mathrm{Sr}$ & $10^{1}$ & $4.424 \mathrm{x}$ & $2.278 \times 10^{17}$ & $6.158 \times 10^{0}$ \\
\hline${ }^{106} \mathrm{Ru}$ & $10^{0}$ & $6.935 \mathrm{x}$ & $8.585 \times 10^{17}$ & $2.320 \times 10^{1}$ \\
\hline${ }^{134} \mathrm{Cs}$ & $10^{0}$ & $3.195 \mathrm{x}$ & $1.531 \times 10^{17}$ & $4.138 \times 10^{0}$ \\
\hline${ }^{125} \mathrm{Sb}$ & $10^{-1}$ & $5.020 x$ & $1.920 \times 10^{16}$ & $5.190 \times 10^{-1}$ \\
\hline${ }^{137} \mathrm{Cs}$ & $10^{1}$ & $8.112 \mathrm{x}$ & $2.597 \times 10^{17}$ & $7.020 \times 10^{0}$ \\
\hline${ }^{144} \mathrm{Ce}$ & $10^{1}$ & $3.322 x$ & $3.922 \times 10^{18}$ & $1.060 \times 10^{2}$ \\
\hline${ }^{236} \mathrm{Pu}$ & $10^{-6}$ & $5.814 x$ & $1 . \mathrm{I} 44 \times 10^{11}$ & $3.093 \times 10^{-6}$ \\
\hline${ }^{238} \mathrm{Pu}$ & $10^{0}$ & $1.479 \mathrm{x}$ & $9.377 \times 10^{14}$ & $2.534 \times 10^{-2}$ \\
\hline${ }^{239} \mathrm{Pu}$ & $10^{2}$ & $4.127 \mathrm{x}$ & $9.480 \times 10^{14}$ & $2.562 \times 10^{-2}$ \\
\hline${ }^{240} \mathrm{Pu}$ & $10^{2}$ & $1.760 x$ & $1.482 \times 10^{15}$ & $4.005 \times 10^{0}$ \\
\hline${ }^{241} \mathrm{Pu}$ & $10^{1}$ & $4.911 \mathrm{x}$ & $1.835 \times 10^{17}$ & $4.958 \times 10^{0}$ \\
\hline${ }^{242} \mathrm{Pu}$ & $10^{1}$ & $1.416 \mathrm{x}$ & $2.061 \times 10^{12}$ & $5.570 \times 10^{-5}$ \\
\hline
\end{tabular}


Table 2. Evacuation from the contaminated areas after the 1986 accident (Aleksakhin et al. 2001)

\begin{tabular}{cccc}
\hline $\begin{array}{c}\text { Zone of evacuation and } \\
\text { resettlement }\end{array}$ & $\begin{array}{c}\text { Area, } \\
\mathbf{k m}^{2}\end{array}$ & $\begin{array}{c}\text { Number of } \\
\text { villages/towns }\end{array}$ & $\begin{array}{c}\text { Number of } \\
\text { people }\end{array}$ \\
\hline Belarus & 1542 & 108 & 24,700 \\
Ukraine & 2157 & 75 & 91,400 \\
Total & 3699 & 187 & 116,300 \\
\hline
\end{tabular}


Table 3. Radioactive materials inventory in the Chernobyl exclusion zone (IAEA Workshop 2006).

\begin{tabular}{|c|c|c|c|c|}
\hline \multirow[t]{2}{*}{ Site } & \multicolumn{4}{|c|}{ Activity, PBq } \\
\hline & Total & ${ }^{137} \mathrm{Cs}$ & ${ }^{90} \mathrm{Sr}$ & $\begin{array}{l}\text { Transuranic } \\
\text { elements }\left(\mathrm{TUE}^{\mathrm{a}}\right)\end{array}$ \\
\hline ChEZ area & 8.13 & 5.5 & 2.5 & 0.13 \\
\hline ChNPP Cooling Pond & 0.22 & 0.19 & 0.03 & 0.002 \\
\hline Radioactive waste disposal site (PZRO) & 5.49 & 3.6 & 1.8 & 0.09 \\
\hline $\begin{array}{l}\text { Radioactive waste interim localization } \\
\text { site (PVLRO) }\end{array}$ & 2.14 & 1.4 & 0.70 & 0.04 \\
\hline TOTAL: & 16.0 & 10.7 & 5 & 0.26 \\
\hline Shelter Facility & 740 & 480 & 260 & 10 \\
\hline $\begin{array}{l}\text { ChNPP spent nuclear fuel (Reactor } \\
\text { Units } 1,2 \text {, and } 3 \text { ) (currently placed in } \\
\text { the retention pools of Reactor Units } 1 \\
\text { and } 2 \text { and in the Spend Nuclear Fuel } \\
\text { Storage Facility } 1 \text { ) }\end{array}$ & \multicolumn{4}{|c|}{ Spent nuclear fuel assemblies - over 21,000 pieces } \\
\hline
\end{tabular}


Table 4. Dynamics of the equivalent dose rate during the first five years following the ChNPP accident.

\begin{tabular}{lrrrrrrr}
\hline Location of monitoring & \multicolumn{8}{c}{ Average annual equivalent dose rate values $\left(\mathbf{m S v ~ h}^{-\mathbf{1}}\right)$} \\
\cline { 2 - 8 } & $\mathbf{1 9 8 6}$ & $\mathbf{1 9 8 7}$ & $\mathbf{1 9 8 8}$ & $\mathbf{1 9 8 9}$ & $\mathbf{1 9 9 0}$ & $\mathbf{1 9 9 1}$ & $\mathbf{1 9 9 2}$ \\
\hline ChNPP Industrial Site & 1700 & 40 & 3 & 1 & 0.42 & 0.35 & 0.2 \\
City of Pripyat & 13.7 & 1.18 & 0.12 & 0.06 & 0.02 & 0.02 & 0.0146 \\
City of Chernobyl & 0.18 & 0.017 & 0.007 & 0.002 & 0.0009 & - & 0.0007 \\
\hline
\end{tabular}


Table 5. Radionuclide Content in the Soil Samples in 1986 (Teplov et al. 1989).

\begin{tabular}{|c|c|c|c|c|c|c|c|c|c|c|c|}
\hline \multirow[b]{2}{*}{ \# Sampling location } & \multirow{2}{*}{$\begin{array}{l}\text { Date of } \\
\text { sampling }\end{array}$} & \multicolumn{10}{|c|}{ Specific activity of radionuclides, $\mathrm{kBq} \mathrm{m}^{-2}$} \\
\hline & & ${ }^{141} \mathrm{Ce}$ & ${ }^{144} \mathrm{Ce}$ & ${ }^{131} \mathbf{I}$ & ${ }^{103} \mathbf{R u}$ & ${ }^{106} \mathrm{Ru}$ & ${ }^{95} \mathbf{Z r}$ & ${ }^{95} \mathrm{Nb}$ & ${ }^{137} \mathrm{Cs}$ & ${ }^{134} \mathrm{Cs}$ & ${ }^{140} \mathbf{L a}$ \\
\hline 1. Chernobyl, soil, $\mathrm{h}=0 \mathrm{~cm}$ & 12.06 & 1517.0 & 2257.0 & 203.5 & 2479.0 & - & 4070.0 & 5550.0 & 247.9 & 151.7 & 703.0 \\
\hline 2. Chernobyl, soil, $\mathrm{h}=0.7 \mathrm{~cm}$ & 12.06 & 11.8 & - & 21.5 & 30.0 & - & 29.6 & 35.9 & 28.9 & 7.0 & 2.6 \\
\hline 3. Chernobyl, soil, $\mathrm{h}=1.5 \mathrm{~cm}$ & 12.06 & 2.4 & - & 7.0 & 4.8 & - & 11.8 & 14.8 & 1.0 & - & - \\
\hline 4. Chernobyl, soil, $\mathrm{h}=0 \mathrm{~cm}$ & 23.06 & 4440.0 & 7770.0 & - & 4070.0 & - & 11470.0 & 16280.0 & 1110.0 & 629.0 & 1036.0 \\
\hline 5. Chernobyl, soil, $\mathrm{h}=1.0 \mathrm{~cm}$ & 23.06 & 28.5 & 66.6 & 21.5 & 44.4 & - & 74.0 & 103.6 & - & - & - \\
\hline 6. Chernobyl, soil, $\mathrm{h}=2.0 \mathrm{~cm}$ & 23.06 & - & - & - & 35.2 & - & - & - & - & - & - \\
\hline 7. Bank of the Pripyat River near the village of & 14.06 & 3700.0 & 5180.0 & 103.6 & 4440.0 & - & 8880.0 & 2210.0 & 740.0 & 344.1 & - \\
\hline 8. 14 Ukrainka Str., Pripyat & 8.08 & 15910.0 & 74000.0 & - & 19610.0 & 13690.0 & 66600.0 & 99900.0 & 5550.0 & 2886.0 & - \\
\hline 9. Pripyat, near the building of the External Health Physics Lab & 8.08 & 7030.03 & 37000.0 & - & 7400.0 & 4810.0 & 26640.0 & 40700.0 & 2738.0 & 1184.0 & - \\
\hline
\end{tabular}


Table 6. Radionuclide concentrations in soils from the "proximity" zone in $1994\left(\mathrm{kBq} \mathrm{m}^{-2}\right)$.

\begin{tabular}{|c|c|c|c|c|c|c|}
\hline \multirow[t]{2}{*}{ Monitoring location } & \multicolumn{3}{|c|}{ Average values } & \multicolumn{3}{|c|}{ Maximum values } \\
\hline & ${ }^{137} \mathrm{Cs}$ & ${ }^{90} \mathrm{Sr}$ & ${ }^{239+240} \mathrm{Pu}$ & ${ }^{137} \mathrm{Cs}$ & ${ }^{90} \mathrm{Sr}$ & ${ }^{239+240} \mathrm{Pu}$ \\
\hline City of Pripyat & 3330 & 1480 & 45.51 & 14800 & 6586 & 203.5 \\
\hline City of Chernobyl & 333 & 314.5 & 3.33 & 481 & 444 & 4.81 \\
\hline 5-km zone & 8510 & 3774 & 116.55 & 66600 & 29600 & 913.9 \\
\hline 5 - $30 \mathrm{~km}$ zone & 1628 & 740 & 22.2 & 10730 & 4773 & 148 \\
\hline $\begin{array}{l}\text { Buryakovka } \\
\text { radioactive waste } \\
\text { disposal site } \\
\text { Podlesny radioactive }\end{array}$ & 136.9 & 59.2 & 1.85 & 251.6 & 111 & 3.33 \\
\hline waste disposal site & 2553 & 1147 & 35.15 & 6290 & 2775 & 86.21 \\
\hline
\end{tabular}


Table 7. Soil concentrations in the 0-5 cm layer at the ASKRO Monitoring Stations in $1994(\mathrm{kBq}$

\begin{tabular}{|c|c|c|c|c|c|c|c|c|}
\hline \# & Sampling location & ${ }^{144} \mathrm{Ce}$ & ${ }^{134} \mathrm{Cs}$ & ${ }^{137} \mathrm{Cs}$ & ${ }^{106} \mathbf{R u}$ & ${ }^{90} \mathrm{Sr}$ & ${ }^{239+240} \mathrm{Pu}$ & ${ }^{238} \mathbf{P u}$ \\
\hline 1. & Benevka & - & 25.9 & 629 & - & 192.4 & 5.92 & 2.849 \\
\hline 2. & Buryakovka & - & 170.2 & 4070 & - & 1998 & 40.7 & 18.5 \\
\hline 3. & Chernobyl & - & 9.25 & 240.5 & - & 70.3 & - & - \\
\hline 4. & Kopachi & - & 26.64 & 666 & - & 192.4 & 5.92 & 2.442 \\
\hline 5. & Chistogalovka & - & 59.2 & 1443 & - & 629 & 19.98 & 9.99 \\
\hline 6. & Pripyat & - & 11.47 & 270.1 & - & 251.6 & 5.55 & 2.442 \\
\hline 7. & Mashevo & - & 107.3 & 2516 & - & 814 & 12.21 & 5.55 \\
\hline 8. & Dityatki & - & - & 11.1 & - & 12.95 & 0.2072 & 0.3145 \\
\hline 9. & Stechanka & - & - & 12.95 & - & 23.68 & 0.1702 & 0.1628 \\
\hline 10. & Zimovitsche & - & 77.7 & 1776 & - & 207.2 & 12.21 & 5.92 \\
\hline 11. & Staroselye & 12.58 & 14.43 & 284.9 & - & 370 & 2.923 & 1.406 \\
\hline 12. & Chernobyl-2 & - & 29.6 & 703 & - & 666 & 8.51 & 4.07 \\
\hline 13. & Shepelichi & - & 21.09 & 481 & 9.62 & 284.9 & 0.666 & 0.1221 \\
\hline 14. & Ilovnitsa & - & 2.664 & 59.2 & 40.7 & 9.62 & 0.555 & 0.2664 \\
\hline 15. & Korogorod & - & 1.221 & 34.04 & - & 5.55 & 0.3515 & 0.1924 \\
\hline 16. & Usov & - & 151.7 & 3700 & - & 2109 & 51.8 & 22.94 \\
\hline 17. & Krivaya Gora & - & 6.29 & 162.8 & - & 244.2 & 2.96 & 1.332 \\
\hline 18. & Krasnoe & 34.04 & 81.4 & 2035 & - & 1517 & 36.63 & 15.54 \\
\hline 19. & Zeleny Mys & - & 1.036 & 24.05 & - & 14.8 & 0.592 & 0.2775 \\
\hline
\end{tabular}


Table 8. Contribution of selected radionuclides into the soil contamination in $1994(\%)$.

\begin{tabular}{cccccc}
\hline${ }^{134} \mathbf{C s}$ & ${ }^{137} \mathbf{C s}$ & ${ }^{90} \mathbf{S r}$ & ${ }^{\left({ }^{239+240)} \mathbf{P u}\right.}$ & ${ }^{{ }^{238}} \mathbf{P u}$ & Total \\
\hline 2.5 & 67 & 29.1 & 0.92 & 0.44 & 99.96 \\
\hline
\end{tabular}


Table 9. Inventory of long-lived radionuclides in the $5 \mathrm{~cm}$ thick soil layer in the 30 $\mathrm{km}$ zone (exclusive of the activity at the waste disposal sites and the ChNPP Cooling Pond), TBq (Vasilchenko et al. 1990).

\begin{tabular}{ccc}
\hline${ }^{137} \mathbf{C s}$ & ${ }^{{ }^{90}} \mathbf{S r}$ & ${ }^{(239+240)} \mathbf{P u}$ \\
\hline 4,070 & 3,700 & 296 \\
\hline
\end{tabular}


Table 10. Characterization of the soil study experimental sites based on the type of terrain.

\begin{tabular}{|c|c|c|}
\hline Site & Type of terrain & $\begin{array}{c}\text { Absolute } \\
\text { elevations, m } \\
\text { (Baltic System) }\end{array}$ \\
\hline LP-1 & $\begin{array}{l}\text { Accumulative denudation medium level } \\
\text { plain }\end{array}$ & $134.1-134.9$ \\
\hline LP-2 & Denudation plain & $154.0-156.1$ \\
\hline LP-3 & $\begin{array}{l}\text { Accumulative denudation high level } \\
\text { plain }\end{array}$ & $141.3-143.6$ \\
\hline LP-4 & $\begin{array}{l}\text { Gradual sloping of the accumulative } \\
\text { denudation high elvel plain }\end{array}$ & $137.8-140.7$ \\
\hline LP-5 & First above flood non-meliorated terrace & $110.5-113.0$ \\
\hline LP-6 & Leveled segmental floodplain & $106.5-108.1$ \\
\hline LP-7 & $\begin{array}{l}\text { First above the floodplain meliorated } \\
\text { terrace }\end{array}$ & $115.5-116.4$ \\
\hline LP-8 & $\begin{array}{l}\text { Steep sloping of the accumulative } \\
\text { denudation high level plain }\end{array}$ & $135.4-140.1$ \\
\hline LP-9 & $\begin{array}{l}\text { Leveled segmental technogenically } \\
\text { altered floodplain }\end{array}$ & $106.5-107.6$ \\
\hline LP-10 & Sand massif (secured sands) & $110.8-112.8$ \\
\hline
\end{tabular}


Table 11. Average transuranic concentrations in soils of various types of terrains at soil study sites in $2009\left(\mathrm{kBq} \mathrm{m}^{-2}\right)$.

\begin{tabular}{lcccccc}
\hline \multirow{2}{*}{ Types of terrain } & \multicolumn{2}{c}{${ }^{\mathbf{2 3 8}} \mathbf{P u}$} & \multicolumn{2}{c}{${ }^{\mathbf{2 3 9}+\mathbf{2 4 0}} \mathbf{P u}$} & \multicolumn{2}{c}{${ }^{\mathbf{2 4 1}} \mathbf{A m}$} \\
\cline { 2 - 7 } & $\mathbf{m i n}$ & $\mathbf{m a x}$ & $\mathbf{m i n}$ & $\mathbf{m a x}$ & $\mathbf{m i n}$ & $\mathbf{m a x}$ \\
\hline Watershed plains & 0.1 & 8.1 & 0.3 & 19.2 & 0.7 & 60 \\
$\begin{array}{l}\text { Above the floodplain } \\
\text { terraces }\end{array}$ & 0.08 & 24 & 0.2 & 55 & 0.4 & 106 \\
Floodplain areas & 6.0 & 270 & 15 & 630 & 52 & 880 \\
\hline
\end{tabular}


Table 12. ${ }^{137} \mathrm{Cs}$ vertical distribution at soil study sites in 2009 (\% of the total activity).

\begin{tabular}{|c|c|c|c|c|c|c|c|c|c|c|c|c|c|}
\hline \multirow{2}{*}{$\begin{array}{c}\text { Soil } \\
\text { layer, } \mathrm{cm}\end{array}$} & \multicolumn{13}{|c|}{ Soil Study Site } \\
\hline & 1 & 2 & 3 & 4 & 5 & 6 & 7 & 8 & 9 & 10 & 11 & 12 & 13 \\
\hline $0-5$ & 79 & 71 & 57 & 52 & 79 & 96 & 85 & 81 & 17 & 65 & 88 & 88 & 76 \\
\hline $5-10$ & 12 & 11 & 27 & 15 & 19 & 1.8 & 8.7 & 11 & 12 & 13 & 6.7 & 1.4 & 8.3 \\
\hline $10-15$ & 6.1 & 0.6 & 7.8 & 9.4 & 1.2 & 0.8 & 3.6 & 4.6 & 62 & 8.3 & 2.7 & 9.5 & 3.6 \\
\hline $15-20$ & 0.3 & 7.1 & 3.8 & 5.1 & 0.3 & 1.2 & 1.1 & 1.4 & 7.2 & 2.1 & 1.1 & 0.6 & 8.9 \\
\hline $20-25$ & 1.1 & 4.9 & 2.8 & 4.2 & 0.2 & 0.04 & 0.2 & 0.4 & 1.2 & 2.7 & 0.5 & 0.2 & 1.7 \\
\hline $25-30$ & 0.1 & 1.3 & 0.9 & 3.2 & 0.1 & 0.1 & 0.2 & 0.5 & 0.3 & 2.6 & 0.3 & 0.1 & 0.6 \\
\hline $30-35$ & 0.2 & 1.3 & 0.2 & 4.8 & 0.1 & 0.02 & 0.2 & 0.1 & 0.1 & 1.8 & 0.2 & 0.1 & 0.2 \\
\hline $35-40$ & 0.2 & 1.4 & 0.4 & 3.2 & 0.1 & 0.1 & 0.3 & 0.2 & 0.1 & 1.4 & 0.2 & 0.3 & 0.2 \\
\hline $40-45$ & 0.2 & 0.8 & 0.4 & 1.6 & 0.1 & 0.01 & 0.3 & 0.5 & 0.1 & 1.3 & 0.04 & 0.1 & 0.1 \\
\hline $45-50$ & 0.1 & 1.0 & 0.3 & 0.8 & 0.003 & 0.05 & 0.3 & 0.5 & 0.03 & 1.7 & 0.1 & 0.1 & 0.1 \\
\hline
\end{tabular}


Table 13. ${ }^{90} \mathrm{Sr}$ vertical distribution at soil study sites in 2009 (\% of the total activity).

\begin{tabular}{|c|c|c|c|c|c|c|c|c|c|c|c|c|c|}
\hline \multirow{2}{*}{$\begin{array}{c}\text { Soil } \\
\text { layer, } \mathrm{cm}\end{array}$} & \multicolumn{13}{|c|}{ Soil Study Site } \\
\hline & 1 & 2 & 3 & 4 & 5 & 6 & 7 & 8 & 9 & 10 & 11 & 12 & 13 \\
\hline $0-5$ & 43 & 27 & 16 & 38 & 39 & 21 & 92 & 33 & 5.6 & 34 & 59 & 91 & 40 \\
\hline $5-10$ & 15 & 26 & 6.8 & 16 & 12 & 1.4 & 4.9 & 18 & 9.0 & 33 & 23 & 2.5 & 13 \\
\hline $10-15$ & 9.6 & 17 & 13 & 14 & 9.9 & 1.4 & 1.0 & 12 & 44 & 8.0 & 7.5 & 2.0 & 10 \\
\hline $15-20$ & 20 & 16 & 16 & 5.0 & 11 & 2.1 & 0.5 & 9.8 & 17 & 5.5 & 2.3 & 2.6 & 11 \\
\hline $20-25$ & 1.1 & 4.7 & 15 & 5.7 & 9.2 & 1.0 & 0.3 & 6.2 & 9.7 & 4.0 & 1.8 & 0.3 & 6.3 \\
\hline $25-30$ & 3.5 & 3.1 & 15 & 5.5 & 6.4 & 2.7 & 0.2 & 9.7 & 4.2 & 4.2 & 1.7 & 0.2 & 7.0 \\
\hline $30-35$ & 2.3 & 1.8 & 6.1 & 6.0 & 5.8 & 11 & 0.2 & 5.1 & 3.1 & 6.1 & 2.0 & 0.2 & 5.1 \\
\hline $35-40$ & 1.8 & 1.0 & 6.9 & 4.3 & 2.1 & 5.5 & 0.3 & 2.5 & 2.2 & 3.4 & 1.0 & 0.7 & 3.5 \\
\hline $40-45$ & 2.2 & 0.9 & 5.2 & 2.9 & 3.0 & 33 & 0.3 & 2.1 & 3.1 & 1.3 & 0.8 & 0.1 & 1.8 \\
\hline $45-50$ & 0.9 & 0.5 & 0.4 & 2.1 & 1.9 & 21 & 0.2 & 1.3 & 1.6 & 0.4 & 1.2 & 0.1 & 2.3 \\
\hline
\end{tabular}


Table 14. Airborne contamination prior to the 1986 accident (Oskolkov et al. 1996).

\begin{tabular}{|c|c|c|c|c|c|}
\hline \multirow[t]{2}{*}{ Monitoring stations } & \multirow{2}{*}{$\begin{array}{c}\text { Distance and } \\
\text { direction from } \\
\text { the source of } \\
\text { contamination }\end{array}$} & \multirow[t]{2}{*}{ Radionuclide } & \multicolumn{3}{|c|}{ Concentration, $\mathrm{n}^{-9} \mathrm{~Bq}^{-1}$} \\
\hline & & & 1977 & 1979 & $\begin{array}{r}1985-1986 \\
\left(1^{\text {st }} \text { Quarter }\right)\end{array}$ \\
\hline \multirow[b]{2}{*}{ Pripyat } & \multirow{2}{*}{$40 \mathrm{~km}, 295^{\circ}$} & ${ }^{137} \mathrm{Cs}$ & 3.70 & 8.51 & 5.92 \\
\hline & & ${ }^{90} \mathrm{Sr}$ & 3.70 & 9.99 & 11.8 \\
\hline \multirow{2}{*}{ Petroleum depot } & \multirow{2}{*}{$2 \mathrm{~km}, 348^{\circ}$} & ${ }^{137} \mathrm{Cs}$ & 4.44 & 13.0 & 7.40 \\
\hline & & ${ }^{90} \mathrm{Sr}$ & 4.07 & 14.4 & 7.59 \\
\hline \multirow{2}{*}{$\begin{array}{l}\text { Zorin entry control } \\
\text { point }\end{array}$} & \multirow{2}{*}{$35 \mathrm{~km}, 172^{\circ}$} & ${ }^{137} \mathrm{Cs}$ & 5.92 & 7.77 & 2.59 \\
\hline & & ${ }^{90} \mathrm{Sr}$ & 7.03 & 11.1 & 2.22 \\
\hline
\end{tabular}


Table 15. Air sampling data for the ChNPP site, city of Pripyat, and city of Chernobyl (Bq L $\mathrm{B}^{-1}$ ) (Teplov et al. 1989).

\begin{tabular}{|c|c|c|c|c|c|c|c|c|c|c|}
\hline Sampling location & Date & ${ }^{141} \mathrm{Ce}$ & ${ }^{144} \mathrm{Ce}$ & ${ }^{131} \mathbf{I}$ & ${ }^{103} \mathbf{R u}$ & ${ }^{95} \mathrm{Zr}$ & ${ }^{95} \mathbf{N b}$ & ${ }^{137} \mathrm{Cs}$ & ${ }^{134} \mathrm{Cs}$ & ${ }^{140} \mathbf{L a}$ \\
\hline $\begin{array}{l}\text { Roof of the turbine hall } \\
\text { of ChNPP Reactor Unit } 1\end{array}$ & June 11 & $5.92 \times 10^{-1}$ & $8.14 \times 10^{-1}$ & $4.07 \times 10^{-2}$ & $5.92 \times 10^{-1}$ & 1.41 & 1.81 & $1.30 \times 10^{-1}$ & $3.52 \cdot 10^{-2}$ & $2.07 \times 10^{-1}$ \\
\hline City of Pripyat, air & June 11 & $1.85 \times 10^{-2}$ & $2.37 \times 10^{-2}$ & - & $4.44 \times 10^{-2}$ & $4.07 \times 10^{-2}$ & $4.81 \times 10^{-2}$ & - & - & - \\
\hline City of Chernobyl, air & June 12 & $5.18 \times 10^{-4}$ & $8.14 \times 10^{-4}$ & - & $5.18 \times 10^{-4}$ & $1.22 \times 10^{-3}$ & $1.63 \times 10^{-4}$ & $1.04 \times 10^{-4}$ & - & $3.22 \times 10^{-4}$ \\
\hline $\begin{array}{l}\text { City of Pripyat, vertically } \\
\text { exposed napkins }\end{array}$ & June 11 & $3.11 \times 10^{+4}$ & $3.52 \times 10^{+4}$ & - & $8.14 \times 10^{+3}$ & $4.81 \times 10^{+4}$ & $5.55 \times 10^{+4}$ & $2.96 \times 10^{+3}$ & - & $2.15 \times 10^{+4}$ \\
\hline $\begin{array}{l}\text { City of Pripyat, } \\
\text { horizontally exposed } \\
\text { napkins }\end{array}$ & June 11 & $4.44 \times 10^{+4}$ & $6.29 \times 10^{+4}$ & - & $3.15 \times 10^{+4}$ & $9.25 \times 10^{+4}$ & $9.62 \times 10^{+4}$ & $6.66 \times 10^{+3}$ & - & $1.18 \times 10^{+4}$ \\
\hline
\end{tabular}


Table 16. Radionuclide composition of the airborne contamination at the ChNPP industrial site in July 1986 (Teplov et al. 1989).

\begin{tabular}{lcccccccc}
\hline Radionuclides & ${ }^{144} \mathbf{C e}$ & ${ }^{141} \mathbf{C e}$ & ${ }^{103} \mathbf{R u}$ & ${ }^{106} \mathbf{R u}$ & ${ }^{137} \mathbf{C s}$ & ${ }^{95} \mathbf{Z r}$ & ${ }^{95} \mathbf{N b}$ & ${ }^{134} \mathbf{C s}$ \\
$\begin{array}{l}\text { Fraction of the total } \\
\text { activity, \% }\end{array}$ & $12.5-18.0$ & $4.3-7.4$ & $8.6-23.0$ & $3.6-12.1$ & $1.1-17.2$ & $17.4-25.6$ & $26.8-38.5$ & $0.4-3.0$ \\
\hline Average & 15.4 & 5.7 & 13.7 & 6.8 & 3.0 & 21.3 & 32.0 & \\
\hline
\end{tabular}


Table17. Activity distribution in aerosol particle sizes (Teplov et al. 1989).

\begin{tabular}{lcccc}
\hline Particle size in fractions, $\boldsymbol{\mu m}$ & $\mathbf{0}-\mathbf{1}$ & $\mathbf{0}-\mathbf{3}$ & $\mathbf{0}-\mathbf{8}$ & $\mathbf{8}$ \\
\hline Activity, $\%$ & $0.4-12.5$ & $3-20$ & $30-50$ & $50-70$ \\
Average, $\%$ & 5 & 12 & 46 & 54 \\
\hline
\end{tabular}


Table 18. Changes in the radionuclide composition of aerosols in the ChNPP proximity zone (\% of total) (Vasilchenko et al. 1990).

\begin{tabular}{cccc}
\hline Radionuclide & September 1987 & July 1988 & July 1989 \\
\hline${ }^{144} \mathrm{Ce}$ & 54.4 & 46.9 & 31.2 \\
${ }^{134} \mathrm{Cs}$ & 3.85 & 5.0 & 5.8 \\
${ }^{\mathrm{I}}{ }^{37} \mathrm{Cs}$ & 13.8 & 22.6 & 35.8 \\
${ }^{95} \mathrm{Zr}$ & 1.85 & - & - \\
${ }^{95} \mathrm{Nb}$ & 3.65 & - & - \\
${ }^{106} \mathrm{Ru}$ & 17.2 & 17.0 & 13.8 \\
${ }^{90} \mathrm{Sr}$ & 5.0 & 8.25 & 13.0 \\
${ }^{239}, 240 \mathrm{Pu}$ & 0.15 & 0.25 & 0.4 \\
\hline
\end{tabular}


Table 19. Average annual concentrations of the total airborne activity in areas around ChNPP, $\mathrm{Bq} \mathrm{L}^{-1}$. ( $\mathrm{V}$ is a factor of concentration decrease) (Vasilchenko et al. 1990).

\begin{tabular}{cccc}
\hline Area (radius, km) & $\mathbf{1 9 8 7}$ & $\mathbf{1 9 8 8}$ & $\mathbf{V}$ \\
\hline $0-1$ & $1,258 \times 10^{-5}$ & $1,258 \times 10^{-6}$ & 10 \\
$1-3$ & $259 \times 10^{-5}$ & $196.1 \times 10^{-6}$ & 13 \\
$3-5$ & $51.8 \times 10^{-5}$ & $7.03 \times 10^{-6}$ & 7 \\
$5-15$ & $10.36 \times 10^{-5}$ & $34.78 \times 10^{-6}$ & 3 \\
$15-30$ & $2.072 \times 10^{-5}$ & $13.69 \times 10^{-6}$ & 1.5 \\
\hline
\end{tabular}


Table 20. Dynamics of the average monthly airborne radionuclide concentrations in 1986-1991 (Korotkov et al. 1992).

\begin{tabular}{cccc}
\hline Location & Year & $\begin{array}{c}\text { Measured concentration, } \\
\mathbf{B q ~ L}^{-1}\end{array}$ & $\begin{array}{c}\text { Maximum allowable } \\
\text { concentration, (DK } \\
\text { Bq }_{\mathbf{B}} \mathbf{L}^{-1}\end{array}$ \\
\hline $\begin{array}{c}\text { ChNPP industrial site } \\
\text { (ORU-750) }\end{array}$ & 1987 & $0.00018-0.00066$ & - \\
& 1988 & $0.00001-0.00018$ & 0.0002 \\
& 1989 & $0.000009-0.00011$ & 0.0001 \\
& 1990 & $0.000006-0.000006$ & 0.00008 \\
\hline City of Pripyat & 1991 & $0.00037-0.2923$ & \\
& 1986 & $0.000026-0.00185$ & \\
& 1987 & $0.000005-0.000074$ & \\
& 1988 & $0.000003-0.00011$ & \\
& 1989 & $0.000001-0.000019$ & \\
& 1990 & $0.00018-0.00066$ & \\
\hline
\end{tabular}


Table 21. Changes in airborne ${ }^{137} \mathrm{Cs}$ concentrations during $1987-2009\left(\mathrm{~Bq} \mathrm{~m}^{-3}\right)$.

\begin{tabular}{|c|c|c|c|c|c|c|c|c|c|c|c|c|c|c|}
\hline $\begin{array}{l}\text { Monitoring } \\
\text { stations }\end{array}$ & $\begin{array}{l}\text { Distance } \\
\text { from } \\
\text { ChNPP, } \\
\text { azimuth }\end{array}$ & 1987 & 1988 & 1989 & 1990 & 1991 & 1992 & 1993 & 1994 & 1995 & 1996 & 1997 & 1998 & 1999 \\
\hline ORU-750 & $0.8 \mathrm{~km} ; 180^{\circ}$ & $8.14 \times 10^{-1}$ & $1.18 \times 10^{-2}$ & $3.03 \times 10^{-2}$ & $1.59 \times 10^{-2}$ & $1.30 \times 10^{-2}$ & $9.40 \times 10^{-3}$ & $8.51 \times 10^{-3}$ & $7.40 \times 10^{-3}$ & $3.15 \times 10^{-3}$ & $3.22 \times 10^{-3}$ & $3.03 \times 10^{-3}$ & $2.40 \times 10^{-3}$ & $2.20 \times 10^{-3}$ \\
\hline Petrol & $2 \mathrm{~km} ; 330^{\circ}$ & $3.11 \times 10^{-1}$ & $1.11 \times 10^{-1}$ & $4.44 \times 10^{-2}$ & $1.18 \times 10^{-2}$ & $1.33 \times 10^{-2}$ & & $5.55 \times 10^{-3}$ & $4.81 \times 10^{-3}$ & $1.70 \times 10^{-3}$ & $1.18 \times 10^{-3}$ & $1.07 \times 10^{-3}$ & $6.50 \times 10^{-4}$ & $5.90 \times 10^{-4}$ \\
\hline Pripyat & $3 \mathrm{~km} ; 290^{\circ}$ & & $6.66 \times 10^{-4}$ & $5.92 \times 10^{-4}$ & $2.92 \times 10^{-4}$ & $2.00 \times 10^{-4}$ & $2.89 \times 10^{-4}$ & $1.78 \times 10^{-4}$ & $7.40 \times 10^{-5}$ & $1.04 \times 10^{-4}$ & $4.07 \times 10^{-5}$ & $1.30 \times 10^{-4}$ & $1.50 \times 10^{-4}$ & $7.30 \times 10^{-5}$ \\
\hline $\begin{array}{l}\text { Water pump } \\
\text { station }\end{array}$ & $2.6 \mathrm{~km} ; 85^{\circ}$ & $4.44 \times 10^{-2}$ & $1.44 \times 10^{-2}$ & $1.37 \times 10^{-2}$ & $5.18 \times 10^{-3}$ & $4.81 \times 10^{-3}$ & $2.52 \times 10^{-3}$ & $2.37 \times 10^{-3}$ & $1.67 \times 10^{-3}$ & $7.03 \times 10^{-4}$ & $1.48 \times 10^{-4}$ & $9.99 \times 10^{-4}$ & $5.90 \times 10^{-4}$ & $6.70 \times 10^{-4}$ \\
\hline Mashevo & $11 \mathrm{~km} ; 19^{\circ}$ & & 4.81 & $4.07 \times 10^{-4}$ & $2.96 \times 10^{-5}$ & $2.22 \times 10^{-4}$ & $2.18 \times 10^{-4}$ & $1.78 \times 10^{-4}$ & $2.18 \times 10^{-4}$ & $1.04 \times 10^{-4}$ & $1.11 \times 10^{-4}$ & $1.70 \times 10^{-4}$ & $1.30 \times 10^{-4}$ & $1.30 \times 10^{-4}$ \\
\hline Zimovische & $7 \mathrm{~km} ; 60^{\circ}$ & & $4.81 \times 10^{-4}$ & $3.03 \times 10^{-4}$ & $2.37 \times 10^{-4}$ & $2.18 \times 10^{-4}$ & $1.63 \times 10^{-4}$ & $1.07 \times 10^{-4}$ & $1.44 \times 10^{-4}$ & $7.77 \times 10^{-5}$ & $7.40 \times 10^{-5}$ & $1.37 \times 10^{-4}$ & $9.80 \times 10^{-5}$ & $7.30 \times 10^{-5}$ \\
\hline Staroselye & $9 \mathrm{~km} ; 119^{\circ}$ & & $2.26 \times 10^{-4}$ & $2.07 \times 10^{-4}$ & $1.74 \times 10^{-4}$ & $1.11 \times 10^{-4}$ & $1.18 \times 10^{-4}$ & $1.15 \times 10^{-4}$ & $7.40 \times 10^{-5}$ & $5.55 \times 10^{-5}$ & $5.55 \times 10^{-5}$ & $1.11 \times 10^{-4}$ & $4.80 \times 10^{-5}$ & $6.10 \times 10^{-5}$ \\
\hline Kopachi & $7 \mathrm{~km} ; 60^{\circ}$ & & $4.81 \times 10^{-4}$ & $4.81 \times 10^{-4}$ & $2.29 \times 10^{-4}$ & $2.52 \times 10^{-4}$ & $1.55 \times 10^{-4}$ & $9.99 \times 10^{-5}$ & $1.04 \times 10^{-4}$ & $9.62 \times 10^{-5}$ & $9.25 \times 10^{-5}$ & $1.67 \times 10^{-4}$ & $2.90 \times 10^{-4}$ & $1.90 \times 10^{-4}$ \\
\hline lobyl & $16 \mathrm{kn}$ & & $4.07 \times 10^{-4}$ & $5.55 \times 10^{-4}$ & $1.48 \times 10^{-4}$ & $1.41 \times 10^{-4}$ & $2.48 \times 10^{-4}$ & $1.07 \times 10^{-4}$ & $6.29 \times 10^{-5}$ & $8.14 \times 10^{-5}$ & $5.18 \times 10^{-5}$ & $8.51 \times 10^{-5}$ & $4.10 \times 10^{-5}$ & $4.70 \times 10^{-5}$ \\
\hline Dityatki & $32 \mathrm{kr}$ & & $8.14 \times 10^{-5}$ & $1.37 \times 10^{-4}$ & $4.44 \times 10^{-5}$ & $5.55 \times 10^{-5}$ & $5.92 \times 10^{-5}$ & $2.22 \times 10^{-5}$ & $4.81 \times 10^{-5}$ & $2.22 \times 10^{-5}$ & $1.89 \times 10^{-5}$ & $3.15 \times 10^{-5}$ & $2.40 \times 10^{-5}$ & $1.90 \times 10^{-5}$ \\
\hline Chistogalo & $7 \mathrm{~km} ; 240^{\circ}$ & & $4.07 \times 10^{-4}$ & $4.07 \times 10^{-4}$ & $2.33 \times 10^{-4}$ & $1.15 \times 10^{-4}$ & $1.18 \times 10^{-4}$ & $1.22 \times 10^{-4}$ & $1.04 \times 10^{-4}$ & $1.18 \times 10^{-4}$ & $1.04 \times 10^{-4}$ & $1.04 \times 10^{-4}$ & $4.40 \times 10^{-5}$ & $3.50 \times 10^{-5}$ \\
\hline & $10 \mathrm{~km} ; 306^{\circ}$ & & & $2.44 \times 10^{-4}$ & $8.14 \times 10^{-5}$ & $1.04 \mathrm{x}$ & $1.85 \times 10^{-4}$ & $9.62 \times 1$ & $8.51 \times 1$ & $7.40 \mathrm{x}$ & $4.44 \mathrm{x}$ & $4.44 \times 10^{-5}$ & $4.70 \times 10^{-5}$ & $4.10 \times 10^{-5}$ \\
\hline Buryakovka & $13 \mathrm{~km} ; 268^{\circ}$ & & $1.07 \times 10^{-3}$ & $9.25 \times 10^{-4}$ & $2.70 \times 10^{-4}$ & $1.96 \times 10^{-4}$ & $2.92 \times 10^{-4}$ & $1.33 \times 10^{-4}$ & $9.99 \times 10^{-5}$ & $8.88 \times 10^{-5}$ & $9.62 \times 10^{-5}$ & $1.15 \times 10^{-4}$ & $1.90 \times 10^{-5}$ & $1.70 \times 10^{-5}$ \\
\hline
\end{tabular}


Table 21 Cont.. Changes in airborne ${ }^{137}$ Cs concentrations during 1987-2009 (Bq m $\left.{ }^{-3}\right)$.

\begin{tabular}{|c|c|c|c|c|c|c|c|c|c|c|c|}
\hline $\begin{array}{c}\text { Monitoring } \\
\text { stations }\end{array}$ & $\begin{array}{c}\text { Distance } \\
\text { from } \\
\text { ChNPP, } \\
\text { azimuth }\end{array}$ & 2000 & 2001 & 2002 & 2003 & 2004 & 2005 & 2006 & 2007 & 2008 & 2009 \\
\hline ORU-750 & $0.8 \mathrm{~km} ; 180$ & $2.20 \times 10^{-3}$ & $2.8 \times 10^{-3}$ & $1.5 \times 10^{-3}$ & $2.2 \times 10^{-3}$ & $1.7 \times 10^{-3}$ & $1.4 \times 10^{-3}$ & $1.4 \times 10^{-3}$ & $1.6 \times 10^{-3}$ & $1.1 \times 10^{-3}$ & $1.1 \times 10^{-3}$ \\
\hline $\begin{array}{l}\text { Petroleum } \\
\text { depot }\end{array}$ & $2 \mathrm{~km} ; 330^{\circ}$ & $4.80 \times 10^{-4}$ & $5.8 \times 10^{-4}$ & $6.3 \times 10^{-4}$ & $8.1 \times 10^{-4}$ & $6.7 \times 10^{-4}$ & $4.4 \times 10^{-4}$ & $3.9 \times 10^{-4}$ & $3.9 \times 10^{-4}$ & $4.7 \times 10^{-4}$ & $3.0 \times 10^{-4}$ \\
\hline Pripyat & $3 \mathrm{~km} ; 290^{\circ}$ & & $1.0 \times 10^{-4}$ & $1.8 \times 10^{-4}$ & $3.2 \times 10^{-4}$ & $2.3 \times 10^{-4}$ & $1.8 \times 10^{-4}$ & $1.5 \times 10^{-4}$ & $8.7 \times 10^{-5}$ & $9.3 \times 10^{-5}$ & $3.1 \times 10^{-4}$ \\
\hline $\begin{array}{l}\text { Water pump } \\
\text { station }\end{array}$ & $2.6 \mathrm{~km} ; 85^{\circ}$ & $1.10 \times 10^{-4}$ & $1.5 \times 10^{-4}$ & $1.1 \times 10^{-3}$ & $7.1 \times 10^{-4}$ & $7.6 \times 10^{-4}$ & $8.6 \times 10^{-4}$ & $1.7 \times 10^{-3}$ & $4.5 \times 10^{-4}$ & $1.4 \times 10^{-4}$ & $2.8 \times 10^{-4}$ \\
\hline Mashevo & $11 \mathrm{~km} ; 19^{\circ}$ & $1.10 \times 10^{-3}$ & $1.0 \times 10^{-3}$ & $1.1 \times 10^{-4}$ & $9.2 \times 10^{-5}$ & $1.1 \times 10^{-4}$ & $1.0 \times 10^{-4}$ & $9.3 \times 10^{-5}$ & $1.1 \times 10^{-4}$ & $8.7 \times 10^{-5}$ & $7.8 \times 10^{-5}$ \\
\hline Zimovische & $7 \mathrm{~km} ; 60^{\circ}$ & $6.40 \times 10^{-5}$ & $6.0 \times 10^{-5}$ & $5.8 \times 10^{-5}$ & $6.0 \times 10^{-5}$ & $5.7 \times 10^{-5}$ & $7.9 \times 10^{-5}$ & $9.5 \times 10^{-5}$ & $5.2 \times 10^{-5}$ & $4.9 \times 10^{-5}$ & $4.1 \times 10^{-5}$ \\
\hline Staroselye & $9 \mathrm{~km} ; 119^{\circ}$ & $4.90 \times 10^{-5}$ & $4.3 \times 10^{-5}$ & $3.7 \times 10^{-5}$ & $3.8 \times 10^{-5}$ & $5.1 \times 10^{-5}$ & $5.8 \times 10^{-5}$ & $4.3 \times 10^{-5}$ & $2.2 \times 10^{-5}$ & $2.7 \times 10^{-5}$ & $3.3 \times 10^{-5}$ \\
\hline Kopachi & $7 \mathrm{~km} ; 60^{\circ}$ & $6.10 \times 10^{-5}$ & $4.1 \times 10^{-5}$ & $5.0 \times 10^{-5}$ & $6.9 \times 10^{-5}$ & $7.3 \times 10^{-5}$ & $7.3 \times 10^{-5}$ & $7.6 \times 10^{-5}$ & $3.4 \times 10^{-5}$ & $4.6 \times 10^{-5}$ & $4.9 \times 10^{-5}$ \\
\hline Chernobyl & $16 \mathrm{~km} ; 147^{\circ}$ & $4.80 \times 10^{-5}$ & $3.8 \times 10^{-5}$ & $3.1 \times 10^{-5}$ & $3.2 \times 10^{-5}$ & $2.6 \times 10^{-5}$ & $3.0 \times 10^{-5}$ & $3.0 \times 10^{-5}$ & $2.0 \times 10^{-5}$ & $1.7 \times 10^{-5}$ & $2.1 \times 10^{-5}$ \\
\hline Dityatki & $32 \mathrm{~km} ; 175^{\circ}$ & $1.80 \times 10^{-5}$ & $2.1 \times 10^{-5}$ & $1.3 \times 10^{-5}$ & $1.6 \times 10^{-5}$ & $2.0 \times 10^{-5}$ & $2.0 \times 10^{-5}$ & $1.6 \times 10^{-5}$ & $9.1 \times 10^{-6}$ & $1.1 \times 10^{-5}$ & $1.3 \times 10^{-5}$ \\
\hline Chistogalovka & $7 \mathrm{~km} ; 240^{\circ}$ & $7.60 \times 10^{-5}$ & $6.6 \times 10^{-5}$ & $7.1 \times 10^{-5}$ & $6.2 \times 10^{-5}$ & $1.3 \times 10^{-4}$ & $1.2 \times 10^{-4}$ & $9.6 \times 10^{-5}$ & $5.5 \times 10^{-5}$ & $6.8 \times 10^{-5}$ & $7.9 \times 10^{-5}$ \\
\hline Benevka & $10 \mathrm{~km} ; 306^{\circ}$ & $4.60 \times 10^{-4}$ & $4.1 \times 10^{-4}$ & $3.1 \times 10^{-5}$ & $3.4 \times 10^{-5}$ & $4.2 \times 10^{-5}$ & $5.4 \times 10^{-5}$ & $3.8 \times 10^{-5}$ & $2.2 \times 10^{-5}$ & $3.9 \times 10^{-5}$ & $3.1 \times 10^{-5}$ \\
\hline Buryakovka & $13 \mathrm{~km} ; 268^{\circ}$ & $1.30 \times 10^{-3}$ & $4.3 \times 10^{-4}$ & $7.6 \times 10^{-5}$ & $6.8 \times 10^{-5}$ & $7.0 \times 10^{-5}$ & $6.3 \times 10^{-5}$ & $1.1 \times 10^{-4}$ & $5.6 \times 10^{-5}$ & $1.6 \times 10^{-4}$ & $9.1 \times 10^{-5}$ \\
\hline
\end{tabular}


Table 22. Long-term dynamics of the airborne contamination in the proximity monitoring area ${ }^{\mathrm{a}}$.

\begin{tabular}{cccccccc}
\hline Year & \multicolumn{6}{c}{ Radionuclide composition and content in air samples, \% } \\
\cline { 2 - 7 } & ${ }^{\mathbf{1 3 4}} \mathbf{C s}$ & ${ }^{\mathbf{1 3 7}} \mathbf{C s}$ & ${ }^{\mathbf{9 0}} \mathbf{S r}$ & ${ }^{23 \mathbf{P u}}$ & ${ }^{239+240} \mathbf{P u}-$ & ${ }^{241} \mathbf{P u}$ & ${ }^{241} \mathbf{A m}$ \\
\hline 1995 & 1.57 & 62.34 & 19.83 & 0.14 & 0.29 & 15.51 & 0.32 \\
1996 & 1.35 & 64.76 & 18.49 & 0.13 & 0.28 & 14.06 & 0.33 \\
1997 & 1.40 & 68.0 & 17.0 & 0.12 & 0.24 & 12.0 & 0.28 \\
1998 & 0.92 & 65.0 & 19.0 & 0.13 & 0.29 & 14.0 & 0.36 \\
1999 & 0.53 & 67.0 & 21.0 & 0.12 & 0.25 & 10.0 & 0.47 \\
2000 & 0.67 & 66.0 & 21.0 & 0.11 & 0.22 & 11.7 & 0.30 \\
2001 & 0.53 & 67.0 & 21.0 & 0.12 & 0.25 & 10.0 & 0.47 \\
2002 & 0.24 & 72.0 & 19.0 & 0.09 & 0.23 & 8.0 & 0.44 \\
2003 & 0.21 & 73.0 & 19.0 & 0.09 & 0.22 & 7.0 & 0.48 \\
2004 & 0.22 & 72.7 & 18.2 & 0.11 & 0.23 & 8.1 & 0.44 \\
2005 & 0.09 & 74.0 & 19.0 & 0.10 & 0.20 & 6.3 & 0.31 \\
2006 & 0.07 & 73.0 & 20.0 & 0.10 & 0.20 & 6.2 & 0.43 \\
2007 & 0.08 & 73.0 & 19.0 & 0.10 & 0.21 & 7.3 & 0.31 \\
2008 & - & 71.0 & 23.0 & 0.09 & 0.19 & 5.2 & 0.67 \\
\hline
\end{tabular}

${ }^{\mathrm{a}}$ Average values for all monitoring stations of the proximity area. 
Table 23. ${ }^{137} \mathrm{Cs}$ content in precipitation (fallout) in 1993-1996.

\begin{tabular}{|c|c|c|c|c|}
\hline \multirow[t]{2}{*}{ Monitoring station } & \multicolumn{4}{|c|}{ Average ${ }^{137} \mathrm{Cs}$ concentration value, $\mathrm{Bq}\left(\mathrm{d} \mathrm{km}^{2}\right)^{-1}$} \\
\hline & 1993 & 1994 & 1995 & 1996 \\
\hline \multicolumn{5}{|l|}{ Reference grid } \\
\hline $1 \mathrm{~km}$ north & 7788.5 & 6482.4 & 9179.7 & 5542.6 \\
\hline $1 \mathrm{~km}$ northeast & 11396 & 8288 & 1152.5 & 11555.1 \\
\hline $1 \mathrm{~km}$ east & 7174.3 & 4983.9 & 4399.3 & 5390.9 \\
\hline $1 \mathrm{~km}$ southwest & 2086.8 & 1879.6 & 2260.7 & 1750.1 \\
\hline $1 \mathrm{~km}$ west & 9083.5 & 2297.7 & 10286 & 11884.4 \\
\hline $1 \mathrm{~km}$ south & 3581.6 & 4499.2 & 2627 & 2301.4 \\
\hline $3 \mathrm{~km}$ northeast & 3296.7 & 4787.8 & 2619.6 & 3925.7 \\
\hline $3 \mathrm{~km}$ northwest & 6027.3 & 3204.2 & 6623 & 3563.1 \\
\hline $3 \mathrm{~km}$ southeast & 869.5 & 1472.6 & 1250.6 & 1010.1 \\
\hline $5 \mathrm{~km}$ southwest & 1054.5 & 506.9 & 410.7 & 595.7 \\
\hline $5 \mathrm{~km}$ west & 1187.7 & 662.3 & 617.9 & 525.4 \\
\hline $5 \mathrm{~km}$ southeast & 2083.1 & 1172.9 & 1583.6 & 632.7 \\
\hline \multicolumn{5}{|l|}{ North Sector } \\
\hline Petroleum depot & - & - & 20871.7 & 11680.9 \\
\hline Krasnoe & 484.7 & 451.4 & 362.6 & 469.9 \\
\hline Mashevo & 566.1 & 358.9 & 444 & 473.6 \\
\hline Usov & 395.9 & 414.4 & 669.7 & 440.3 \\
\hline \multicolumn{5}{|l|}{ East Sector } \\
\hline Water pump station & - & - & 3714.8 & 3200.5 \\
\hline Zimovische & 614.2 & 310.8 & 299.7 & 373.7 \\
\hline Krivaya Gora & 529.1 & 407 & 362.6 & 418.1 \\
\hline Staroselye & 244.2 & 451.4 & 277.5 & 218.3 \\
\hline \multicolumn{5}{|l|}{ South Sector } \\
\hline Kopachi & 658.6 & 288.6 & 273.8 & 321.9 \\
\hline Chernobyl-2 & 462.5 & 270.1 & 410.7 & 333 \\
\hline Korogorod & 288.6 & 277.5 & 795.5 & 259 \\
\hline Chernobyl ASKRO & 865.8 & 469.9 & 603.1 & 392.2 \\
\hline Chernobyl stadium & - & - & 321.9 & 351.5 \\
\hline Ilovnitsa & 532.8 & 469.9 & 662.3 & 747.4 \\
\hline Dityatki & 196.1 & 155.4 & 192.4 & 144.3 \\
\hline Zeleny Mys & 292.3 & 185 & 177.6 & 170.2 \\
\hline \multicolumn{5}{|l|}{ West Sector } \\
\hline Pripyat ASKRO & 1979.5 & 1039.7 & 1557.7 & 1376.4 \\
\hline Chistogalovka & 762.2 & 351.5 & 599.4 & 473.6 \\
\hline Benevka & 392.2 & 640.1 & 321.9 & 251.6 \\
\hline Shepelichi station & 410.7 & 684.5 & 344.1 & 340.4 \\
\hline Buryakovka & 1165.5 & 995.3 & 710.4 & 847.3 \\
\hline Stechanka & 425.5 & 159.1 & 236.8 & 140.6 \\
\hline
\end{tabular}


Table 24. ${ }^{137} \mathrm{Cs}$ fallout intensity at ChEZ monitoring stations in 2006.

\begin{tabular}{|c|c|c|c|c|c|}
\hline \multirow{2}{*}{ Monitoring station } & \multirow{2}{*}{$\begin{array}{c}\text { Distance from } \\
\text { the ChNPP, } \\
\text { km, azimuth }\end{array}$} & \multicolumn{3}{|c|}{ Intensity, $\mathrm{Bq}\left(\mathrm{m}^{2} \mathrm{~d}\right)^{-1}$} & \multirow{2}{*}{$\begin{array}{l}\text { Seasonal } \\
\text { (summer/ } \\
\text { winter) ratio }\end{array}$} \\
\hline & & Min & Average & Max & \\
\hline \multicolumn{6}{|l|}{ North sector } \\
\hline Petroleum depot & $2 \mathrm{~km}, 330^{\circ}$ & 0.16 & 3.0 & 6.0 & 1.2 \\
\hline Mashevo & $11 \mathrm{~km}, 19^{\circ}$ & 0.04 & 0.31 & 1.2 & 1.4 \\
\hline Podlesny RW disposal site & $1.9 \mathrm{~km}, 350^{\circ}$ & 0.12 & 1.0 & 4.0 & 2.4 \\
\hline \multicolumn{6}{|l|}{ East Sector } \\
\hline BNS-3 & $2.6 \mathrm{~km}, 85^{\circ}$ & 0.17 & 1.0 & 2.5 & 1.1 \\
\hline Zimovye & $7 \mathrm{~km}, 60^{\circ}$ & 0.07 & 0.28 & 0.84 & 1.9 \\
\hline Staroselye & $9 \mathrm{~km}, 119^{\circ}$ & 0.04 & 1.2 & 14 & 2.5 \\
\hline \multicolumn{6}{|l|}{ South sector } \\
\hline $\begin{array}{l}\text { ChNPP Phase } 3 \mathrm{RW} \text { disposal } \\
\text { site (Kompleksny) }\end{array}$ & $1.9 \mathrm{~km}, 120^{\circ}$ & 0.04 & 2.1 & 22 & 6.2 \\
\hline Kopachi & $5 \mathrm{~km}, 155^{\circ}$ & 0.02 & 0.34 & 1.4 & 2.8 \\
\hline Chernobyl & $16 \mathrm{~km}, 147^{\circ}$ & 0.04 & 0.27 & 0.81 & 1.3 \\
\hline $\begin{array}{l}\text { Lelev decontamination } \\
\text { facility }\end{array}$ & $11 \mathrm{~km}, 150^{\circ}$ & 0.06 & 0.37 & 4.2 & 3.9 \\
\hline SNFSF-2 & $2.2 \mathrm{~km}, 149^{\circ}$ & 0.10 & 1.1 & 5.3 & 4.4 \\
\hline Dityatki & $32 \mathrm{~km}, 175^{\circ}$ & 0.07 & 0.58 & 7.1 & 6.7 \\
\hline \multicolumn{6}{|l|}{ West sector } \\
\hline Chistogalovka & $7 \mathrm{~km}, 240^{\circ}$ & 0.03 & 0.69 & 3.8 & 1.4 \\
\hline Benevka & $10 \mathrm{~km}, 306^{\circ}$ & 0.04 & 0.24 & 0.79 & 1.7 \\
\hline Buryakovka & $13 \mathrm{~km}, 268^{\circ}$ & 0.04 & 0.30 & 0.93 & 2.2 \\
\hline $\begin{array}{l}\text { Buryakovka RW disposal site } \\
\text { (center) }\end{array}$ & $12.5 \mathrm{~km}, 250^{\circ}$ & 0.04 & 0.29 & 1.5 & 1.4 \\
\hline $\begin{array}{l}\text { Buryakovka RW disposal site } \\
\text { (100 m south of the center) }\end{array}$ & $12.5 \mathrm{~km}, 247^{\circ}$ & 0.11 & 0.78 & 5.5 & 3.9 \\
\hline $\begin{array}{l}\text { Buryakovka RW disposal site } \\
\text { (100 m north of the center) }\end{array}$ & $12.5 \mathrm{~km}, 250^{\circ}$ & 0.04 & 0.38 & 2.7 & 2.3 \\
\hline Vektor Enteprise & $13 \mathrm{~km}, 244^{\circ}$ & 0.05 & 0.33 & 1.3 & 2.9 \\
\hline
\end{tabular}


Table 25. Dynamics of airborne radionuclide concentrations at the ChNPP industrial site.

\begin{tabular}{|c|c|c|c|c|c|c|c|}
\hline \multirow[t]{2}{*}{ Year } & \multicolumn{6}{|c|}{ Radionuclide concentrations $^{\mathrm{a}}, \mathrm{Bq}^{-3}$} & \multirow{2}{*}{$\begin{array}{l}\text { Operational mode of the } \\
\text { ChNPP power reactors }\end{array}$} \\
\hline & ${ }^{137} \mathrm{Cs}$ & ${ }^{90} \mathrm{Sr}$ & ${ }^{238} \mathbf{P u}$ & ${ }^{239+240} \mathrm{Pu}$ & ${ }^{241} \mathbf{P u}$ & ${ }^{241} \mathrm{Am}$ & \\
\hline 1998 & $2.4 \times 10^{-3}$ & $4.7 \times 10^{-4}$ & $4.4 \times 10^{-6}$ & $7.9 \times 10^{-6}$ & $39 \times 105$ & $39 \times 10^{-5}$ & normal \\
\hline 1999 & $2.3 \times 10^{-3}$ & $4.6 \times 10^{-4}$ & $4.1 \times 10^{-6}$ & $8.1 \times 10^{-6}$ & $41 \times 10^{-5}$ & $41 \times 10^{-5}$ & normal \\
\hline 2000 & $2.2 \times 10^{-3}$ & $6.4 \times 10^{-4}$ & $4.4 \times 10^{-6}$ & $9.2 \times 10^{-6}$ & $33 \times 10^{-5}$ & $33 \times 10^{-5}$ & normal \\
\hline 2001 & $2.7 \times 10^{-3}$ & $4.2 \times 10^{-4}$ & $2.3 \times 10^{-6}$ & $6.0 \times 10^{-6}$ & $31 \times 10^{-5}$ & $31 \times 10^{-5}$ & decommissioning \\
\hline 2002 & $1.8 \times 10^{-3}$ & $2.9 \times 10^{-4}$ & $2.4 \times 10^{-6}$ & $4.6 \times 10^{-6}$ & $20 \times 10^{-5}$ & $20 \times 10^{-5}$ & -66 \\
\hline 2003 & $1.3 \times 10^{-3}$ & $2.5 \times 10^{-4}$ & $2.3 \times 10^{-6}$ & $3.0 \times 10^{-6}$ & $14 \times 10^{-5}$ & $14 \times 10^{-5}$ & -“" \\
\hline 2004 & $1.4 \times 10^{-3}$ & $2.7 \times 10^{-4}$ & $2.3 \times 10^{-6}$ & $3.6 \times 10^{-6}$ & $12 \times 10^{-5}$ & $17 \times 10^{-5}$ & -“' \\
\hline 2005 & $1.7 \times 10^{-3}$ & $2.9 \times 10^{-4}$ & $2.3 \times 10^{-6}$ & $3.6 \times 10^{-6}$ & $15 \times 10^{-5}$ & $17 \times 10^{-5}$ & -“" \\
\hline 2006 & $1.5 \times 10^{-3}$ & $2.8 \times 10^{-4}$ & $2.1 \times 10^{-6}$ & $3.1 \times 10^{-6}$ & $12 \times 10^{-5}$ & $16 \times 10^{-5}$ & - “' \\
\hline
\end{tabular}

${ }^{\mathrm{a}}$ The State Specialized Enterprise ChAES data (average annual values for all stations) 
Table 26. Estimated annual radionuclide release through ChNPP ventilation stacks ${ }^{\mathrm{a}}$.

\begin{tabular}{|c|c|c|c|c|c|}
\hline \multirow{3}{*}{ Year } & \multicolumn{4}{|c|}{ Release activity, MBq } & \multirow{3}{*}{$\begin{array}{c}\text { Operational mode } \\
\text { of the ChNPP } \\
\text { power reactors }\end{array}$} \\
\hline & \multicolumn{2}{|c|}{$\begin{array}{c}\text { Reactor } 1 \\
\text { ventilation stack }\end{array}$} & \multicolumn{2}{|c|}{$\begin{array}{c}\text { Reactor } 2 \\
\text { ventilation stack }\end{array}$} & \\
\hline & ${ }^{137} \mathrm{Cs}$ & ${ }^{90} \mathrm{Sr}$ & ${ }^{137} \mathrm{Cs}$ & ${ }^{90} \mathrm{Sr}$ & \\
\hline 2000 & 18 & 3.1 & 510 & 60 & $\begin{array}{l}\text { Normal (until 15 } \\
\text { December 2000) }\end{array}$ \\
\hline 2001 & 23 & 2.4 & 300 & 14 & Decommissioned \\
\hline 2002 & 23 & 3.3 & 190 & 8.9 & Decommissioned \\
\hline 2003 & 4.6 & none & 73 & 9.5 & Decommissioned \\
\hline 2004 & 6.3 & none & 58 & 9.6 & Decommissioned \\
\hline 2005 & 12 & none & 58 & 24 & Decommissioned \\
\hline 2006 & 6.0 & none & 110 & 10 & Decommissioned \\
\hline 2007 & 19 & none & 133 & 11 & Decommissioned \\
\hline
\end{tabular}

${ }^{\text {a }}$ The State Specialized Enterprise ChAES data. 
Table 27. Radionuclide concentrations in selected elements of the ChNPP cooling pond ecosystem in 1981 (Kazakov 1995).

\begin{tabular}{|c|c|c|c|c|c|}
\hline \multirow{2}{*}{$\begin{array}{l}\text { Element of } \\
\text { the ecosystem }\end{array}$} & \multirow{2}{*}{$\begin{array}{c}\text { Total } \\
\text { estimated } \\
\text { mass, kg }\end{array}$} & \multicolumn{4}{|c|}{ Specific activity, $\mathrm{Bq} \cdot \mathrm{kg}^{-1}$} \\
\hline & & ${ }^{54} \mathrm{Mn}$ & ${ }^{60} \mathrm{Co}$ & ${ }^{134} \mathrm{Cs}$ & ${ }^{137} \mathrm{Cs}$ \\
\hline Water & $1.4 \times 10^{11}$ & $8.9 \times 10^{-4}$ & $1.2 \times 10^{-3}$ & $7.4 \times 10^{-3}$ & $1.8 \times 10^{-2}$ \\
\hline Seston & $3.0 \times 10^{6}$ & $1.4 \times 10^{2}$ & $2.6 \times 10^{2}$ & 18.0 & 63.0 \\
\hline Mollusks & $6.0 \times 10^{6}$ & 3.7 & 0.93 & 1.2 & 1.8 \\
\hline Periphyton & $1.0 \times 10^{7}$ & 1.8 & 1.7 & 1.8 & 5.2 \\
\hline Fish & $2.0 \times 10^{5}$ & 0.74 & 0.37 & 1.5 & 4.8 \\
\hline Algae & $2.0-1.0 \times 10^{5}$ & $1.5-2.6$ & $0.9-1.5$ & $0.93-3.7$ & $2.6-5.6$ \\
\hline Sand & $11.8 \times 10^{8}$ & 7.4 & 18.5 & 3.7 & 24.7 \\
\hline Silt & $4.2 \times 10^{8}$ & 74 & $1.1 \times 10^{2}$ & 37 & $4.7 \times 10^{3}$ \\
\hline
\end{tabular}


Table 28. Maximum contamination levels of the Pripyat river water in May1986 (Pashevich and Kononovich 1986).

\begin{tabular}{cccc}
\hline Radionuclide & $\begin{array}{c}\text { Maximum activity, } \\
\mathbf{B q ~ L}^{-\mathbf{1}}\end{array}$ & Radionuclide & $\begin{array}{c}\text { Maximum activity, } \\
\mathbf{B q ~ L}^{-\mathbf{- 1}}\end{array}$ \\
\hline${ }^{137} \mathrm{Cs}$ & 1591 & ${ }^{106} \mathrm{Ru}$ & $271^{\mathrm{b}}$ \\
${ }^{134} \mathrm{Cs}$ & $827^{\mathrm{a}}$ & ${ }^{144} \mathrm{Ce}$ & 380 \\
${ }^{131} \mathrm{I}$ & 4,440 & ${ }^{141} \mathrm{Ce}$ & 400 \\
${ }^{90} \mathrm{Sr}$ & 30 & ${ }^{95} \mathrm{Zr}$ & 1554 \\
${ }^{140} \mathrm{Ba}$ & ${ }^{95} \mathrm{Nb}$ & 420 \\
${ }^{99} \mathrm{Mo}$ & 1,400 & ${ }^{241} \mathrm{Pu}$ & $33^{\mathrm{c}}$ \\
${ }^{103} \mathrm{Ru}$ & 670 & ${ }^{239+240} \mathrm{Pu}$ & 0.4 \\
\hline
\end{tabular}

${ }^{\mathrm{a}}$ Based on the ${ }^{134} \mathrm{Cs} /{ }^{137} \mathrm{Cs}$ ratio $(\approx 0.52)$.

${ }^{\mathrm{b}}$ The ${ }^{103} \mathrm{Ru}$ estimate is based on the ${ }^{103} \mathrm{Ru} /{ }^{106} \mathrm{Ru}$ ratio $(\approx 3)$ for the aerosols released from the ChNPP destroyed reactor.

${ }^{\mathrm{c}}$ Based on the ${ }^{241} \mathrm{Pu} /{ }^{239+240} \mathrm{Pu}$ ratio $(\approx 82)$ in the aerosols. 
Table 29. Radionuclide concentrations in water samples on 9 June 1986, Bq L ${ }^{-1}$ (Teplov et al. 1989).

\begin{tabular}{|c|c|c|c|c|c|c|c|c|}
\hline \# & Location of sampling & ${ }^{141} \mathrm{Ce}$ & ${ }^{131} \mathbf{I}$ & ${ }^{103} \mathbf{R u}$ & ${ }^{95} \mathbf{Z r}$ & ${ }^{95} \mathrm{Nb}$ & ${ }^{137} \mathrm{Cs}$ & ${ }^{140} \mathbf{L a}$ \\
\hline 1 & ChNPP Cooling Pond & 3,515 & 1221 & 3330 & 9620 & 12950 & 740 & 2405 \\
\hline 2 & ChNPP Cooling Pond Feed Canal & 592 & 444 & 251.6 & 962 & 1258 & 407 & $<185$ \\
\hline \multirow[t]{2}{*}{3} & ChNPP Cooling Pond Discharge & & & & & & & \\
\hline & Canal & 740 & 592 & 518 & 1628 & 2701 & 740 & $<185$ \\
\hline 4 & Drainage Canal & 125.8 & 299.7 & 481 & 666 & 999 & 281.2 & 358.9 \\
\hline 5 & Pripyat River & 214.6 & $<111$ & $<148$ & 444 & 740 & 177.6 & $<185$ \\
\hline 6 & Drainage & 103.6 & $<111$ & $<148$ & 407 & 777 & $<111$ & $<185$ \\
\hline 7 & $\begin{array}{l}\text { Kiev Water Reservoir near the } \\
\text { village of Strakholesye }(40 \mathrm{~cm} \\
\text { above the bottom) }\end{array}$ & 2183 & 140.6 & 1628 & 3552 & 4440 & 140.6 & 444 \\
\hline 8 & $\begin{array}{l}\text { Kiev Water Reservoir near the } \\
\text { village of Strakholesye (on the } \\
\text { surface) }\end{array}$ & 444 & $<111$ & 703 & 1147 & 1517 & 99.9 & $<185$ \\
\hline \multirow[t]{2}{*}{9} & Flush water at the Vehicle & & & & & & & \\
\hline & Decontamination Facility (PuSO) & 1739 & 777 & 3330 & 4440 & 5550 & 11470 & 1073 \\
\hline
\end{tabular}


Table 30. Estimated total radioactive contamination of ChNPP cooling pond water in May-June 1986 data (Kazakov 1995).

\begin{tabular}{|c|c|c|c|c|c|c|c|c|c|c|}
\hline Isotope & ${ }^{141} \mathrm{Ce}$ & ${ }^{144} \mathrm{Ce}$ & ${ }^{103} \mathrm{Ru}$ & ${ }^{140} \mathbf{B a}$ & ${ }^{131} \mathbf{I}$ & ${ }^{95} \mathrm{Zr}$ & ${ }^{95} \mathrm{Nb}$ & ${ }^{140} \mathrm{La}$ & ${ }^{134} \mathrm{Cs}$ & ${ }^{137} \mathrm{Cs}$ \\
\hline $\mathrm{TBq}$ & $9.62-16.7$ & $9.62-16.7$ & $18.5-29.6$ & $37.0-62.9$ & $85.1-137.0$ & $229.0-370.0$ & $27.8-44.4$ & $31.5-51.8$ & $20.4-33.3$ & $40.7-66.6$ \\
\hline
\end{tabular}


Table 31. Quantitative assessments of the natural decontamination of the ChNPP cooling pond water (Egorov et al. 1988; Kazakov 1995)

\begin{tabular}{cccc}
\hline Radionuclide & $\begin{array}{c}\text { Physical decay } \\
\text { constant, } \mathbf{d}^{\mathbf{- 1}}\end{array}$ & $\begin{array}{c}\text { Water natural } \\
\text { decontamination } \\
\text { constant, } \mathbf{d}^{\mathbf{- 1}}\end{array}$ & $\begin{array}{c}\text { Half-clearance period, } \\
\mathbf{T}_{\mathbf{1} / \mathbf{2}} \text { decont, }\end{array}$ \\
\hline${ }^{141} \mathrm{Ce}$ & 0.021 & $0.099-0.149$ & $4.1-5.5$ \\
${ }^{144} \mathrm{Ce}$ & 0.0024 & $0.12-0.17$ & $4.1-5.5$ \\
${ }^{103} \mathrm{Ru}$ & 0.0176 & $0.092-0.132$ & $4.6-6.5$ \\
${ }^{140} \mathrm{Ba}$ & 0.0542 & $0.066-0.106$ & $4.3-5.8$ \\
${ }^{131} \mathrm{I}$ & 0.086 & $0.011-0.034$ & $8.9-7.1$ \\
${ }^{95} \mathrm{Zr}$ & 0.0108 & $0.109-0.149$ & $4.4-6.0$ \\
${ }^{96} \mathrm{Nb}$ & 0.0198 & $0.1-0.14$ & $4.2-5.6$ \\
${ }^{140} \mathrm{La}$ & 0.413 & $0.066-0.106$ & $4.3-6.8$ \\
${ }^{134} \mathrm{Cs}$ & $9.21 \cdot 10^{-4}$ & $0.037-0.072$ & $9.5-18.3$ \\
${ }^{137} \mathrm{Cs}$ & $6.35 \cdot 10^{-5}$ & $0.041-0.077$ & $9-17$ \\
\hline
\end{tabular}

Note:

1. $T_{1 / 2 \text { decont. }}=0.693 /\left(\lambda_{\text {decont. }}\right)$.

2. The ${ }^{140} \mathrm{La}$ half-life constant is based on its formation in the ${ }^{140} \mathrm{Ba} /{ }^{140} \mathrm{La}$ chain. 
Table 32. ${ }^{90} \mathrm{Sr}$ and ${ }^{137} \mathrm{Cs}$ releases to the Kiev water reservoir by the Pripyat and Dnieper rivers (TBq) (Afonin and Magus 1992).

\begin{tabular}{|c|c|c|c|c|}
\hline \multirow[t]{2}{*}{ Year } & \multicolumn{2}{|c|}{$\begin{array}{l}\text { Pripyat River (the city of Chernobyl } \\
\text { section) }\end{array}$} & \multicolumn{2}{|c|}{$\begin{array}{l}\text { Dnieper River (the village of } \\
\text { Nedanchichi sector) }\end{array}$} \\
\hline & ${ }^{90} \mathrm{Sr}$ & ${ }^{137} \mathrm{Cs}$ & ${ }^{90} \mathrm{Sr}$ & ${ }^{137} \mathrm{Cs}$ \\
\hline 1986 & 3.7 & 21.8 & 3.7 & 15.4 \\
\hline 1987 & 10.7 & 15.2 & 9.25 & 12.6 \\
\hline 1988 & 18.5 & 9.25 & 5.18 & 9.62 \\
\hline 1989 & 9.25 & 4.81 & 3.7 & 7.4 \\
\hline 1990 & 9.62 & 2.59 & 3.33 & 4.44 \\
\hline
\end{tabular}


Table 33. ${ }^{137} \mathrm{Cs}$ and ${ }^{90} \mathrm{Sr}$ content in the surface water of the ChEZ major monitored bodies of water in 1992-2009 (average activity, kBq $\mathrm{m}^{-3}$ ).

\begin{tabular}{|c|c|c|c|c|c|c|c|c|c|c|c|c|c|c|c|c|c|c|c|}
\hline \multirow{2}{*}{ eservoirs name } & \multirow{2}{*}{ Juclide } & \multicolumn{18}{|c|}{ Year } \\
\hline & & 92 & 1993 & 1994 & 1995 & 1996 & 1997 & 1998 & 1999 & 2000 & 2001 & 002 & 2003 & 2004 & 2005 & 2006 & 007 & 2008 & 2009 \\
\hline \multirow{2}{*}{ Prypyat (entry ChEZ) } & & 28 & 8 & 22 & 10 & 2 & 0.13 & 0.13 & 1 & 10 & 10 & 97 & .06 & 0.05 & 0.07 & .05 & 0.05 & .03 & 0.03 \\
\hline & & .28 & 0.32 & 0.41 & 0.11 & 0.14 & 0.07 & 0.12 & 16 & 0.09 & 0.09 & 0.05 & 0.04 & 0.04 & 0.07 & 04 & 0.04 & 03 & 0.04 \\
\hline \multirow{2}{*}{$\begin{array}{l}\text { Prypyat (section line - } \\
\text { Chornobyl) }\end{array}$} & ${ }^{137} \mathrm{Cs}$ & 1 & 0.21 & 0.20 & 0.11 & 0.13 & 0.16 & 0.14 & 0.15 & 0.11 & 0.12 & 0.08 & 0.05 & 0.05 & 0.09 & 0.07 & 0.05 & 0.06 & 0.04 \\
\hline & ${ }^{90} \mathrm{Sr}$ & 44 & 0.85 & 0.93 & 0.33 & 0.34 & 0.25 & 0.30 & 0.50 & 0.22 & 0.23 & 0.17 & 0.15 & 0.18 & 0.19 & 0.16 & 0.12 & .10 & 11 \\
\hline \multirow[t]{2}{*}{ r. Yzh (v. Cherevatch) } & ${ }^{137} \mathrm{Cs}$ & $022-3$ & 0.20 & 0.17 & 0.13 & 0.33 & 0.08 & 0.14 & 0.10 & 0.10 & 0.09 & 0.07 & 0.06 & 0.06 & 0.07 & 0.07 & 0.07 & .04 & 0.04 \\
\hline & ${ }^{90} \mathrm{Sr}$ & & 0.81 & 0.56 & 0.31 & 0.63 & 0.26 & 0.32 & 25 & 0.16 & 0.18 & 0.08 & 0.11 & 0.17 & 0.14 & 0.13 & 0.09 & 0.10 & 0.10 \\
\hline \multirow{2}{*}{$\begin{array}{l}\text { r.Sachan - (v. } \\
\text { N.Shepelichy) }\end{array}$} & ${ }^{137} \mathrm{Cs}$ & 20 & 0.28 & 0.44 & 0.18 & 0.00 & 0.00 & 0.34 & 0.29 & 0.19 & 0.22 & 0.23 & 0.29 & 0.24 & 0.31 & 0.60 & 0.16 & 0.15 & 0.13 \\
\hline & ${ }^{90} \mathrm{Sr}$ & 2.01 & 2.92 & 3.70 & 1.63 & & 0.00 & 50 & & 1.30 & 1.50 & 0.80 & 0.82 & 2.10 & 1.90 & 80 & 1.40 & 90 & 1.90 \\
\hline \multirow{2}{*}{$\begin{array}{l}\text { Glinitsa River - water } \\
\text { passageway }\end{array}$} & ${ }^{137} \mathrm{Cs}$ & 0.30 & 0.48 & 0.41 & 0.37 & 0.20 & 0.10 & 0.47 & 0.37 & 0.36 & 0.31 & 0.61 & 0.61 & 0.46 & 0.39 & 0.49 & 0.26 & 0.31 & 0.28 \\
\hline & ${ }^{90} \mathrm{Sr}$ & 3.11 & 7.77 & 8.14 & 7.40 & 5.55 & 4.44 & 6.30 & 7.30 & 4.50 & 4.60 & 3.60 & 3.70 & 4.80 & 4.60 & 4.20 & 3.30 & 4.00 & 3.50 \\
\hline \multirow{2}{*}{ Cooli } & ${ }^{137} \mathrm{Cs}$ & & & & & & & & & & & & & & .47 & & 1.45 & 38 & 98 \\
\hline & ${ }^{90} \mathrm{Sr}$ & 4.81 & 4.44 & 3.37 & 3.22 & 2.74 & 2.18 & 1.80 & 1.90 & 1.70 & 1.50 & 1.40 & 1.70 & 1.60 & 1.30 & 1.50 & 1.60 & 2.20 & 1.70 \\
\hline \multirow{2}{*}{$\begin{array}{l}\text { Pripyatsky backwater } \\
\text { pond }\end{array}$} & ${ }^{137} \mathrm{Cs}$ & 6.66 & 7.77 & 5.18 & 4.44 & 6.66 & 6.66 & 5.60 & 4.80 & 7.70 & 2.70 & 3.52 & 2.51 & 2.88 & 2.29 & 3.06 & 2.07 & 17 & 2.06 \\
\hline & ${ }^{90} \mathrm{Sr}$ & 81.4 & 81.4 & 78.8 & 64.5 & 47.7 & 29.6 & 22.0 & 42.0 & 49.0 & 26.0 & 23.0 & 22.0 & 19.0 & 17.0 & 16.0 & 13.0 & 11.0 & 10.0 \\
\hline \multirow{2}{*}{$\begin{array}{l}\text { Semikhodsky backwater } \\
\text { pond }\end{array}$} & ${ }^{137} \mathrm{Cs}$ & 1.41 & 0.41 & 1.63 & 0.30 & 1.52 & 1.63 & 1.30 & 2.20 & 2.40 & 1.30 & 1.85 & 1.98 & 1.31 & 3.19 & 2.43 & 1.13 & 1.04 & 1.46 \\
\hline & ${ }^{90} \mathrm{Sr}$ & 28.49 & 55.50 & 62.9 & 45.8 & 29.2 & 17.7 & 23.0 & 36.0 & 30.0 & 16.0 & 17.0 & 14.0 & 14.0 & 17.0 & 13.0 & 11.0 & 8.2 & 7.7 \\
\hline \multirow{2}{*}{$\begin{array}{l}\text { Krasnyansky polder v. } \\
\text { Zymovyche - dam \#7 } \\
\text { closing gap }\end{array}$} & ${ }^{137} \mathrm{Cs}$ & 2.78 & 0.59 & 3.33 & 0.96 & 3.00 & 2.89 & 4.20 & 7.00 & 2.30 & 3.90 & 4.10 & 2.92 & 2.33 & 3.11 & 2.02 & 1.89 & 1.26 & 1.28 \\
\hline & ${ }_{90}^{9} \mathrm{c}$ & 37.0 & 59.2 & 51.8 & 37.0 & 25.5 & 27.0 & 33.0 & 43.0 & 24.0 & 16.0 & 14.0 & 18.0 & 18.0 & 18.0 & 12.0 & 10.0 & 9.70 & 11.00 \\
\hline \multirow{2}{*}{ Glubokoe Lake } & ${ }^{137} \mathrm{Cs}$ & 9.25 & 9.62 & 9.99 & 8.14 & 14.43 & 12.58 & 14.00 & 14.00 & 8.10 & 7.10 & 9.20 & 7.16 & 6.54 & 6.32 & 5.74 & 3.48 & 3.71 & 3.32 \\
\hline & ${ }^{90} \mathrm{Sr}$ & 333.0 & 281.2 & 214.6 & 159.1 & 136.9 & 99.90 & 120.0 & 120.0 & 103.0 & 79.0 & 74.00 & 102.0 & 135.0 & 140.0 & 160.0 & 110.0 & 95.00 & 98.00 \\
\hline \multirow{2}{*}{ Azbuchin Lake } & ${ }^{137} \mathrm{Cs}$ & & & 0.68 & 17.91 & 14.80 & 12.58 & 17.00 & 23.00 & 13.00 & 9.90 & 5.99 & 8.93 & 7.14 & 12.24 & 7.29 & 5.22 & 4.82 & 4.81 \\
\hline & ${ }^{90} \mathrm{Sr}$ & & & 240.5 & 227.5 & 85.10 & 85.10 & 120.0 & 190.0 & 133.0 & 110.0 & 52.00 & 49.00 & 56.00 & 74.00 & 47.00 & 47.00 & 37.00 & 35.00 \\
\hline
\end{tabular}


Table 34. Estimated average annual ${ }^{90} \mathrm{Sr}$ transfer by the ChEZ major aqueous flows in 19992009 (TBq.)

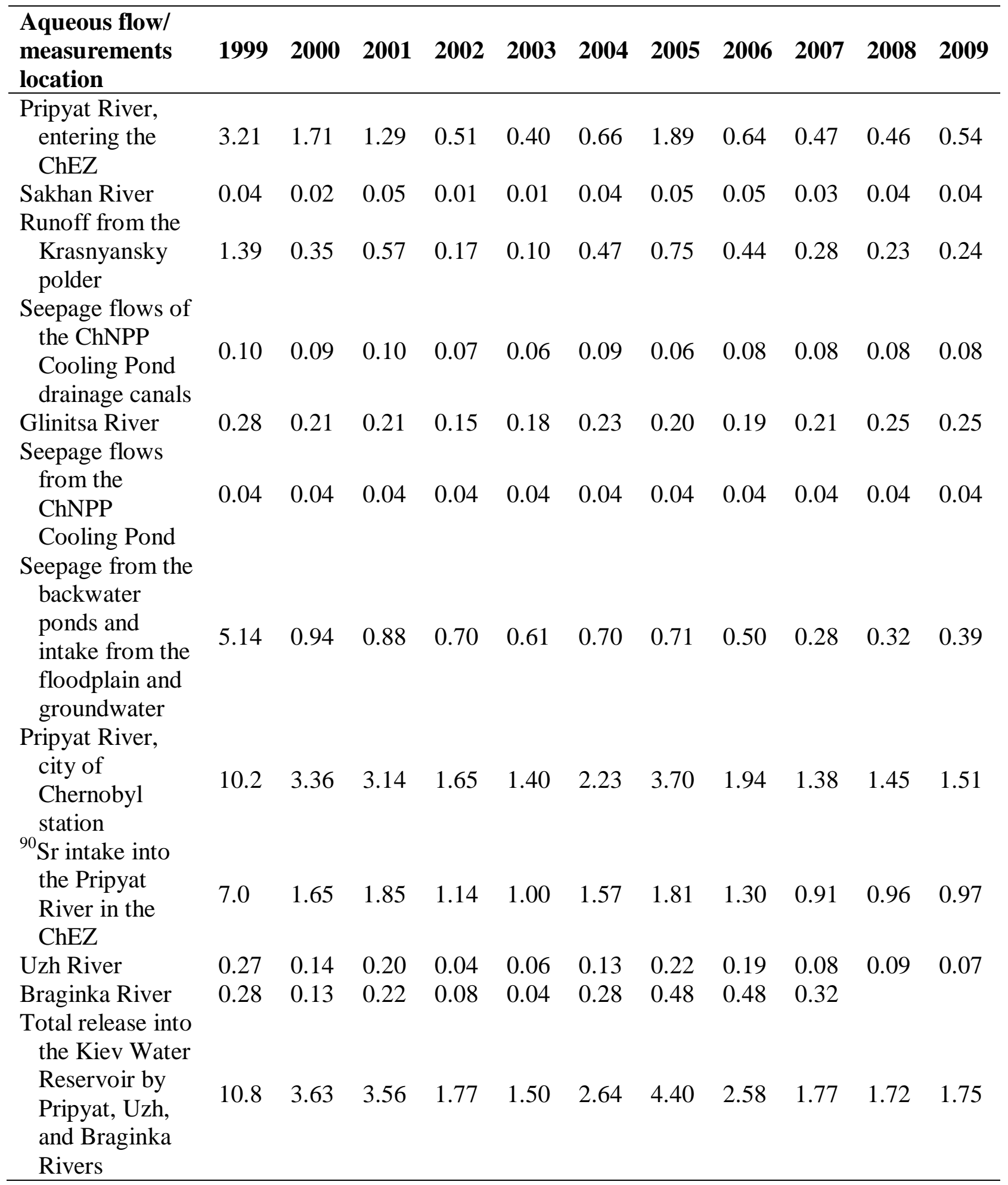


Table 35. ${ }^{90} \mathrm{Sr}$ concentrations in groundwater recorded in selected monitoring wells, $\mathrm{Bq} \mathrm{L}{ }^{-1}$ (Afonin et al. 1992).

\begin{tabular}{|c|c|c|c|c|}
\hline Monitoring well \# & 1989 & 1990 & 1991 & $\begin{array}{c}\text { Maximum } \\
\text { allowable } \\
\text { concentration }\end{array}$ \\
\hline \multicolumn{5}{|c|}{ ChNPP Cooling Pond drainage curtain } \\
\hline $151 / 2$ & $4.81-6.65$ & $17.39-17.76$ & $12.95-20.72$ & 14.8 \\
\hline $151 / 3$ & $5.92-13.32$ & $11.1-19.24$ & $18.87-24.05$ & 14.8 \\
\hline $151 / 3 \kappa$ & $5.92-19.98$ & $11.1-23.31$ & $18.87-19.61$ & 14.8 \\
\hline \multicolumn{5}{|c|}{ ChNPP Cooling Pond radioactive waste interim localization site } \\
\hline 9-к & 32.56 & $62.9-99.9$ & $21.09-40.7$ & 14.8 \\
\hline $16-\kappa$ & & $21.83-25.16$ & $24.05-24.42$ & 14.8 \\
\hline $17-\kappa$ & 40.7 & $59.2-62.9$ & $37-62.9$ & 14.8 \\
\hline $18-\kappa$ & 55.5 & 81.4- 92.5 & $51.8-62.9$ & 14.8 \\
\hline \multicolumn{5}{|c|}{ Red Forest radioactive waste interim localization site } \\
\hline $1 / 1$ & 1.85 & 7.4 & $44.4-59.2$ & 14.8 \\
\hline $2 / 1$ & 1.85 & 0.888 & $11.1-14.8$ & 14.8 \\
\hline \multicolumn{5}{|c|}{ Petroleum depot radioactive waste interim localization site } \\
\hline $1 / 2$ & 0.22 & 2.96 & 16.3 & 14.8 \\
\hline
\end{tabular}


Table 36. Dynamics of ${ }^{90} \mathrm{Sr}$ concentrations in the groundwater in selected radioactive waste interim localization and disposal sites of the ChEZ in 1991-2006 (kBq m$\left.{ }^{-3}\right)(\mathrm{DSNVP}$ EcoCenter 1995-2010).

\begin{tabular}{|c|c|c|c|c|c|c|c|c|c|c|c|c|c|c|c|c|c|c|c|c|}
\hline locat & & & & & & & & & & & & 1 & & & 4 & 5 & 06 & & & 200 \\
\hline \multirow{4}{*}{$\begin{array}{l}\text { Red Forest RW } \\
\text { interim } \\
\text { localization site } \\
\text { (near the } \\
\text { Stroybaza } \\
\text { facility) }\end{array}$} & & 52 & 63 & 55 & 29 & 263 & 23 & 258 & 203 & 180 & 220 & 210 & 240 & 200 & 230 & 230 & 180 & 180 & 210 & 250 \\
\hline & & 5 & 7.4 & 17 & 20 & 10 & 2 & 17 & 10 & 24 & 22 & 29 & 14 & 11 & 6 & 36 & 57 & 5 & 28 & 35 \\
\hline & $2 / 1 \mathrm{D}$ & - & 0.3 & 1.3 & 0.1 & 0.8 & 0.9 & 0.2 & 0.4 & 0.4 & 0.8 & 0.3 & 0.4 & 0.2 & 0.5 & 0.4 & 1.8 & 0.3 & 0.88 & 2.1 \\
\hline & $2 / 2$ & 1.1 & .9 & 3 & 5.2 & 4.8 & 2 & 1 & 35 & 2 & 5 & 32 & 19 & 2 & 47 & 49 & 5 & 0 & 50 & 50 \\
\hline \multirow{7}{*}{$\begin{array}{l}\text { Red Forest RW } \\
\text { interim } \\
\text { localization site } \\
\text { (near the } \\
\text { village of } \\
\text { Lesnoe) }\end{array}$} & K- & 04 & 22 & 15 & 16 & 31 & 2.7 & 26 & 34 & 11 & 18 & 19 & 18 & 4 & 11 & 18 & 31 & 31 & 28 & 24 \\
\hline & & - & 0 & 5 & 0.4 & 0.7 & 0.5 & 0.5 & 0.2 & 3 & 2 & 0.3 & .1 & 3 & 1 & 2 & 1 & 2 & 11 & 0.1 \\
\hline & К-14 & 0.4 & 0.7 & .4 & 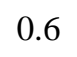 & 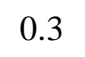 & 0.4 & 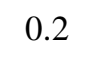 & 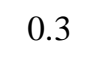 & 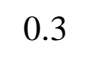 & . & 0.3 & 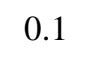 & 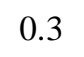 & 0.1 & 0.1 & 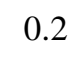 & 0.1 & 0.20 & 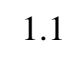 \\
\hline & $\mathrm{K}-14 \mathrm{D}$ & - & 0.2 & 0.3 & 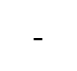 & 0.3 & 0.2 & 0 & 0.3 & 2 & 3 & 0.2 & 1 & 3 & 0.1 & .1 & 2 & .1 & .26 & 0.5 \\
\hline & 1 & - & - & - & - & - & - & 0 & 0.5 & 0.2 & 0.3 & 0 & 0.2 & 0.3 & 2 & 4 & 0.3 & 3 & 62 & 0.7 \\
\hline & $169 / \mathrm{Q} 2$ & - & - & - & - & - & - & 0.6 & 1.0 & 01 & 3 & 0.4 & 0.1 & .4 & 0.1 & 0.2 & 0.4 & 0.2 & 0.33 & 0.6 \\
\hline & & - & - & - & - & - & - & - & 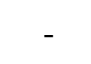 & 0.2 & & 0.3 & 0.1 & .3 & 0.1 & 4 & . T & 2 & .29 & 0.0 \\
\hline \multirow{4}{*}{$\begin{array}{l}\text { Red Forest RW } \\
\text { interim } \\
\text { localization site } \\
\text { (in the area of } \\
\text { the Pripyatsky } \\
\text { backwater } \\
\text { pond) }\end{array}$} & & & 0.6 & 0.4 & 0.4 & 0.5 & 0.2 & 0.3 & 0.4 & 0.2 & 0.5 & 0.6 & 0.5 & 5 & 0.6 & 0.7 & .6 & 2.1 & 2.6 & 2.2 \\
\hline & 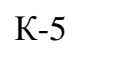 & 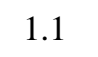 & 0.0 & 1.1 & 1.0 & 1.1 & T. T. & . & . & 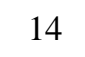 & 20 & 100 & 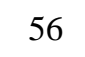 & & 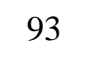 & 10 & 2 & 4.4 & 4.4 & 7.0 \\
\hline & К-6 & 1.5 & 0 & 1.1 & 1.5 & 1.2 & 0.7 & 1.0 & 1.3 & 7.0 & & 3.2 & 1.3 & 2 & 8 & 6 & 0 & 6 & .2 & 8 \\
\hline & K & & 8 & & & 0.2 & 8.5 & 16 & 12 & & & 15 & & & 6 & 0 & 26 & 1 & 29 & 21 \\
\hline \multirow{3}{*}{$\begin{array}{l}\text { Podlesny RW } \\
\text { disposal site }\end{array}$} & 4 & & & & & & & & & & & & & & & & & & & 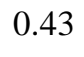 \\
\hline & 10 & & 0 & & & 0 & 04 & 0 & 0 & 07 & 0.2 & 0.1 & 0.2 & 0.3 & 0.2 & 0.2 & 0.6 & 0.5 & 24 & 0.3 \\
\hline & 11 & & 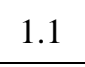 & & & & & & 0.8 & & & 0.2 & & & 0.2 & 0.1 & & & & c \\
\hline \multirow{5}{*}{$\begin{array}{l}\text { Buryakovka } \\
\text { RW disposal } \\
\text { site }\end{array}$} & J & & 07 & & & 07 & 0.2 & 0.2 & 0 & 0.1 & & 0 & 0 & & 0 & 0 & ? & 0.2 & 0.46 & 0. \\
\hline & 14 & 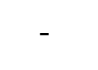 & 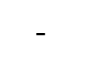 & - & - & - & - & 0.1 & 0.2 & 0.1 & 0.2 & 0.2 & 0.1 & 0.1 & 2 & 0.2 & 0.4 & 0.1 & 4 & ( \\
\hline & 27 & & 11 & & & 04 & 04 & 0 & . & ? ? & & 0 & 0 & 0.3 & 0 & 01 & 04 & 1 & 0.22 & 0 \\
\hline & $\mathrm{J}$ & & 0.1 & & & & & & & & & & & & 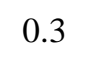 & .1 & & 1.1 & ${ }^{4}$ & 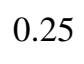 \\
\hline & 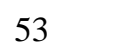 & & 0.7 & 0.4 & & ( 4 & 0.1 & & 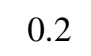 & $0 ?$ & 03 & 0.2 & ? & 01 & 0.3 & 0.1 & ? & 01 & 0.1 & 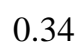 \\
\hline sal & 8 & & 2.6 & & & 2.3 & & & & & & 5 & 1.8 & 1.1 & 8 & 5 & 7 & 8 & .4 & 0.91 \\
\hline \multirow{5}{*}{$\begin{array}{l}\text { ChNPP } \\
\text { Cooling Pond } \\
\text { drainage } \\
\text { curtain, PK-32, } \\
64,113\end{array}$} & 6 & & & & & & & & 1.4 & & & & & & 6.5 & 5.2 & & 4.9 & 0 & 2 \\
\hline & $92 / 1$ & 0.7 & 3.3 & 9.2 & 13 & 12 & 6.3 & 3.6 & 2.0 & 1.9 & 5.2 & 4.6 & 4.0 & 3.4 & 2.5 & 2.4 & 2.3 & 3.2 & 0 & 1 \\
\hline & 92 & 1.0 & 2.0 & 0.2 & & 3.0 & 2.0 & 1.2 & 10 & 1.1 & 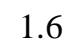 & 1.0 & 3.2 & 4.2 & 3.0 & 4.2 & 7.4 & 5.6 & 3.20 & 4.5 \\
\hline & & 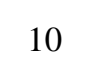 & 7. & 5 & 4.8 & 6.7 & 3 & 2.7 & .9 & 1.7 & 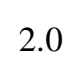 & 1 & 1.8 & 9 & 6 & 1.2 & 9 & 7 & 30 & 1 \\
\hline & $151 / 3 \mathrm{~K}$ & 7.8 & 13 & 8.1 & 9.2 & 7.4 & 4.1 & 5.5 & 2.4 & 2.1 & 2.4 & 1.7 & 2.0 & 2 & 1.7 & 1.6 & 1.6 & 1.5 & 1.70 & 1. \\
\hline \multirow{2}{*}{$\begin{array}{l}\text { ChNPP } \\
\text { Cooling Pond, } \\
\text { PK-14 }\end{array}$} & 2 & 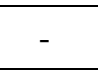 & - & - & 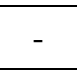 & 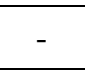 & - & 1 & 1 & 20 & (5) & 2 & 16 & 11 & 8 & 39 & 15 & .0 & 8 & 2.0 \\
\hline & 2 & - & - & - & - & - & - & 61 & 17.7 & 45 & 50 & 27 & 40 & 1 & 19 & 6.6 & 3.5 & 2.2 & 4.3 & 1.6 \\
\hline
\end{tabular}




\begin{tabular}{|c|c|c|c|c|c|c|c|c|c|c|c|c|c|c|c|c|c|c|c|c|}
\hline & 2 & - & - & - & - & - & - & 1.8 & 4.0 & 5.3 & 3.8 & 2.4 & 3.6 & 6.3 & 5.9 & 5.4 & 4.9 & 6.0 & 1.80 & 4.5 \\
\hline \multirow{4}{*}{$\begin{array}{l}\text { Water } \\
\text { remediation } \\
\text { structures in the } \\
\text { Krasnyanskaya } \\
\text { floodplain }\end{array}$} & $201-1$ & - & - & 1.1 & 1.1 & 0.6 & 0.6 & 0.5 & 0.4 & 0.5 & 0.4 & 0.4 & 0.2 & 0.2 & 0.3 & 0.2 & 0.4 & 0.5 & 0.20 & 0.70 \\
\hline & $201 / 1$ & - & - & 5.9 & 1.5 & 1.8 & 1.0 & 0.7 & 0.7 & 0.4 & 0.6 & 0.3 & 0.1 & 0.2 & 0.1 & 0.2 & 0.3 & 0.2 & 0.70 & 0.53 \\
\hline & $203-1$ & - & - & 8.1 & 6.3 & 3.3 & 1.9 & 0.8 & 1.0 & 0.8 & 0.6 & 0.4 & 0.3 & 0.3 & 0.2 & 0.2 & 0.3 & 0.2 & 0.28 & 0.56 \\
\hline & $206-1$ & - & - & 1.5 & 1.1 & 2.4 & 1.1 & 0.3 & 0.3 & 0.3 & 0.3 & 0.3 & 0.2 & 0.2 & 0.2 & 0.2 & 0.3 & 0.3 & 0.22 & 0.30 \\
\hline \multirow{6}{*}{ Azbuchin Lake } & 1 & - & - & - & - & - & - & - & - & - & - & - & - & 45 & 48 & 42 & 43 & 40 & 34 & 31 \\
\hline & $1 \mathrm{~A}$ & - & - & - & - & - & - & - & - & - & - & - & - & 61 & 56 & 48 & 55 & 50 & 41 & 37 \\
\hline & 2 & - & - & - & - & - & - & - & - & - & - & - & - & 35 & 40 & 37 & 40 & 36 & 29 & 24 \\
\hline & $2 \mathrm{~A}$ & - & - & - & - & - & - & - & - & - & - & - & - & 118 & 98 & 84 & 98 & 107 & 100 & 87 \\
\hline & 3 & - & - & - & - & - & - & - & - & - & - & - & - & 3 & 6.6 & 6.7 & 13 & 16 & 7.4 & 14 \\
\hline & $3 \mathrm{~A}$ & - & - & - & - & - & - & - & - & - & - & - & - & 121 & 85 & 79 & 81 & 73 & 60 & 42 \\
\hline $\begin{array}{l}\text { Peschanoe } \\
\text { Plato RW } \\
\text { interim } \\
\text { localization site } \\
\text { (in the area of } \\
\text { the }\end{array}$ & $\mathrm{K}-1$ & 0.8 & 0.6 & 0.6 & 0.5 & 0.4 & 0.7 & 0.6 & 0.6 & 0.5 & 0.2 & 0.2 & 0.4 & 0.3 & 0.4 & 0.4 & 0.3 & 0.4 & 0.79 & 0.60 \\
\hline $\begin{array}{l}\text { Semikhodovsky } \\
\text { backwater } \\
\text { pond) }\end{array}$ & & & & & & & & & & & & & & & & & & & & \\
\hline
\end{tabular}


Table 37. ${ }^{137} \mathrm{Cs}$ concentrations in groundwater at selected areas of the ChNPP proximity zone $\left(\mathrm{kBq} \mathrm{m}^{-3}\right)$.

\begin{tabular}{|c|c|c|c|c|c|c|c|}
\hline \multirow{2}{*}{$\begin{array}{l}\text { Locations of water } \\
\text { sampling from the } \\
\text { wells }\end{array}$} & \multirow[t]{2}{*}{ Well \# } & \multicolumn{3}{|c|}{$\begin{array}{c}{ }^{137} \text { Cs concentration, } \\
2006 \\
\end{array}$} & \multicolumn{3}{|c|}{$\begin{array}{c}{ }^{137} \text { Cs concentration, } \\
2009 \\
\end{array}$} \\
\hline & & Min & Max & Average & Min & Max & Average \\
\hline \multirow{4}{*}{$\begin{array}{l}\text { Red Forest RW interim } \\
\text { localization site (near } \\
\text { the Stroybaza facility) }\end{array}$} & $1 / 1$ & 0.05 & 0.30 & 0.16 & 0.05 & 0.02 & 0.14 \\
\hline & $2 / 1$ & 0.04 & 0.65 & 0.15 & 0.04 & 0.27 & 0.16 \\
\hline & $2 / 1 \mathrm{D}$ & 0.06 & 0.51 & 0.16 & 0.007 & 0.021 & 0.14 \\
\hline & $2 / 2$ & 0.04 & 0.65 & 0.35 & 0.10 & 0.9 & 0.46 \\
\hline \multirow{7}{*}{$\begin{array}{l}\text { Red Forest RW interim } \\
\text { localization site (near } \\
\text { the village of Lesnoe) }\end{array}$} & K-13 & 0.02 & 0.09 & 0.05 & 0.01 & 0.07 & 0.04 \\
\hline & $\mathrm{K}-13 \mathrm{D}$ & 0.02 & 0.10 & 0.04 & 0.01 & 0.01 & 0.01 \\
\hline & K-14 & 0.05 & 0.15 & 0.06 & 0.01 & 0.02 & 0.01 \\
\hline & $\mathrm{K}-14 \mathrm{D}$ & 0.02 & 0.11 & 0.04 & 0.01 & 0.01 & 0.01 \\
\hline & 169/Q1 & 0.04 & 0.07 & 0.06 & 0.02 & 0.07 & 0.05 \\
\hline & 169/Q2 & 0.04 & 0.10 & 0.07 & 0.009 & 0.013 & 0.007 \\
\hline & 169/Q3 & 0.07 & 0.13 & 0.09 & 0.004 & 0.08 & 0.04 \\
\hline \multirow{4}{*}{$\begin{array}{l}\text { Red Forest RW interim } \\
\text { localization site (in the } \\
\text { area of the Yanovsky } \\
\text { backwater pond) }\end{array}$} & K-4 & 0.03 & 0.12 & 0.05 & 0.006 & 0.016 & 0.01 \\
\hline & K-5 & 0.25 & 8.80 & 2.60 & 0.01 & 0.50 & 0.25 \\
\hline & K-6 & 0.04 & 0.17 & 0.10 & 0.15 & 0.10 & 0.13 \\
\hline & K-7 & 0.02 & 0.07 & 0.05 & 0.07 & 0.3 & 0.19 \\
\hline \multirow{3}{*}{$\begin{array}{l}\text { Podlesny RW disposal } \\
\text { site }\end{array}$} & $4 \mathrm{~N}$ & 0.05 & 0.10 & 0.07 & 0.01 & 0.06 & 0.037 \\
\hline & $10 \mathrm{~N}$ & 0.02 & 0.07 & 0.04 & 0.01 & 0.02 & 0.015 \\
\hline & $11 \mathrm{~N}$ & 0.02 & 0.11 & 0.05 & 0.006 & 0.02 & 0.013 \\
\hline \multirow{4}{*}{$\begin{array}{l}\text { ChNPP Phase } 3 \text { RW } \\
\text { disposal site } \\
\text { (Kompleksny disposal } \\
\text { site) }\end{array}$} & 4 "III" & 0.03 & 0.29 & 0.16 & 0.01 & 0.07 & 0.04 \\
\hline & 8 “III" & 0.04 & 0.16 & 0.11 & 0.01 & 0.05 & 0.03 \\
\hline & 14 "III' & 0.29 & 0.31 & 0.30 & 0.03 & 0.14 & 0.09 \\
\hline & 15 "III" & 0.03 & 0.33 & 0.17 & 0.04 & 0.17 & 0.10 \\
\hline \multirow{4}{*}{$\begin{array}{l}\text { Buryakovka RW } \\
\text { disposal site }\end{array}$} & 5 & 0.02 & 0.05 & 0.03 & 0.05 & 0.20 & 0.13 \\
\hline & 14 & 0.04 & 0.05 & 0.05 & 0.01 & 0.04 & 0.03 \\
\hline & 22 & 0.03 & 0.10 & 0.07 & 0.01 & 0.07 & 0.04 \\
\hline & 35 & 0.02 & 0.05 & 0.04 & 0.01 & 0.14 & 0.08 \\
\hline
\end{tabular}


Table 38. Radiation assessment of the drinking water used by the ChNPP personnel ${ }^{\mathrm{a}}$.

\begin{tabular}{|c|c|c|}
\hline \multirow{2}{*}{$\begin{array}{c}\text { Parameters of the radiation assessment } \\
\text { (unit of measurements) }\end{array}$} & \multicolumn{2}{|c|}{ Radionuclides in the drinking water } \\
\hline & ${ }^{90} \mathrm{Sr}, \mathrm{kBq} \mathrm{m}^{-3}$ & ${ }^{137} \mathrm{Cs}, \mathrm{kBq} \mathrm{m}^{-3}$ \\
\hline \multicolumn{3}{|c|}{2006} \\
\hline Actual concentration $(\mathrm{Ci}) ; \mathrm{Bq} \mathrm{L}^{-1}$ & 5 & 4 \\
\hline $\begin{array}{l}\text { Relative concentration }\left(\mathrm{Ci} / \mathrm{DS}_{\mathrm{B}, \mathrm{i}}{ }^{\text {ingest }}\right) \text {; relative } \\
\text { units }\end{array}$ & 0.0005 & 0.00004 \\
\hline Total $\left(\mathrm{Ci} / \mathrm{DS}_{\mathrm{B}, \mathrm{i}}{ }^{\text {ingest }}\right)$; relative units & 0.00054 & \\
\hline \multicolumn{3}{|l|}{ (2) } \\
\hline Actual concentration $(\mathrm{Ci}) ; \mathrm{Bq} \mathrm{L}^{-1}$ & 4 & 3 \\
\hline $\begin{array}{l}\text { Relative concentration }\left(\mathrm{Ci} / \mathrm{DS}_{\mathrm{B}, \mathrm{i}}{ }^{\text {ingest }}\right) \text {; relative } \\
\text { units }\end{array}$ & 0.0004 & 0.00003 \\
\hline Total $\left(\mathrm{Ci} / \mathrm{DS}_{\mathrm{B}, \mathrm{i}}{ }^{\text {ingest }}\right)$; relative units & 0.00043 & \\
\hline
\end{tabular}


Table 39. Characteristics of the radiation status of drinking water used in the city of Chernobyl.

\begin{tabular}{|c|c|c|}
\hline \multirow{2}{*}{$\begin{array}{c}\text { Parameters of the radiation assessment } \\
\text { (unit of measurements) }\end{array}$} & \multicolumn{2}{|c|}{ Radionuclides in the drinking water } \\
\hline & ${ }^{90} \mathrm{Sr}, \mathrm{kBq} \mathrm{m}^{-3}$ & ${ }^{137} \mathrm{Cs}, \mathrm{kBq} \mathrm{m}^{-3}$ \\
\hline \multicolumn{3}{|c|}{2006} \\
\hline Actual concentration & 4 & 6 \\
\hline $\begin{array}{l}\text { Relative concentration }\left(\mathrm{Ci} / \mathrm{DS}_{\mathrm{B}, \mathrm{i}}{ }^{\text {ingest }}\right) \text {, relative } \\
\text { units }\end{array}$ & 0.0004 & 0.00006 \\
\hline Total $\left(\mathrm{Ci} / \mathrm{DS}_{\mathrm{B}, \mathrm{i}}{ }^{\text {ingest }}\right)$, relative units & 0.00046 & \\
\hline \multicolumn{3}{|l|}{$\begin{array}{lllllll} & \\
\end{array}$} \\
\hline Actual concentration & 3 & 4 \\
\hline $\begin{array}{l}\text { Relative concentration }\left(\mathrm{Ci} / \mathrm{DS}_{\mathrm{B}, \mathrm{i}}{ }^{\text {ingest }}\right) \text {, relative } \\
\text { units }\end{array}$ & 0.0003 & 0.00004 \\
\hline Total $\left(\mathrm{Ci} / \mathrm{DS}_{\mathrm{B}, \mathrm{i}}{ }^{\text {ingest }}\right)$, relative units & 0.00034 & \\
\hline
\end{tabular}

